\title{
DESENVOLVIMENTO DE MEMBRANAS DE PVA/COLÁGENO ANIÔNICO COMO NOVOS SISTEMAS POLIMÉRICOS DE LIBERAÇÃO CONTROLADA DE ANTIBIÓTICOS
}

Tese apresentada ao Instituto de Química de São Carlos da Universidade de São Paulo como parte dos requisitos para a obtenção do título de Doutor em Química.

Área de concentração: Química Orgânica e Biológica Orientadora: Prof ${ }^{a}$. Dr ${ }^{a}$. Ana Maria de Guzzi Plepis

São Carlos 

Dou valor às coisas, nâo por aquilo que valem, mas por aquilo que significam.

Gabriel Garcia Márquez Nobel de Literatura, 1982 


\section{AGRADECIMENTOS}

- Agradeço ao universo conhecido e ao mesmo tempo desconhecido, que fez possível a realização e culminação desta obra.

- A mim mesmo por superar as grandes dificuldades que passei durante o doutorado, por não perder a fé própria e não perder a esperança de que ao final as coisas dão certo para quem faz as coisas certas.

- À minha mãe pela fortaleza que me brindou, o amor e por ensinar-me que sempre devo terminar todas as coisas que foram começadas.

- À Profa. Dra . Ana Maria de Guzzi Plepis por me acolher no seu grupo e pela orientação continua.

- À Virginia pelo apoio técnico e pelos seus valiosos aportes à presente pesquisa.

- À Profa. Dra. Ilana Lopes Baratella da Cunha Camargo e à doutoranda Gabriela Marinho Righetto pela sua contribuição no planejamento, execução e redação dos testes antimicrobianos.

- Ao Prof. Dr. Marco Vinícius Chaud pela ajuda na execução e redação dos ensaios mecânicos de tração.

- À Glenda Gisela Ibánez Redín, doutoranda do Grupo de Polimeros "Prof. Bernhard Gross", pela sua assessoria nas medições de ângulo de contato.

- Ao Dr. Martín Emilio González Hernandez e ao técnico Dr. Mauro Roberto Fernandez pela assessoria na obtenção das curvas termogravimétricas.

- Ao Prof. Dr. Alexandre Lima de Andrade e à Profa. Dra ${ }^{a}$. Alessandra de Almeida Lucas, pelas suas indicações em quanto á seleção dos antibióticos e ao formato de membrana adequado para os testes in vivo.

- À Central de Análises Químicas do IQSC/USP pela prestação do serviço para as caracterizações das membranas por espectroscopia infravermelho e Microscopia Eletrônica de Varredura.

- Ao laboratório de Microscopia Eletrônica do IFSC/USP pela prestação do serviço para a caracterização das membranas por Microscopia de Força Atômica. 
- Às pessoas que me acompanharam pessoalmente neste complexo processo e fizeram mais amena a realização deste trabalho.

- Às pessoas do Laboratório de Bioquímica e Biomateriais pela companhia e os bons cafés.

- À universidade de São Paulo e ao Instituto de química de São Carlos pela oportunidade de cursar o doutorado e ao CNPq pela bolsa concedida. 


\section{RESUMO}

DAZA, Jorge Humberto Unás. Desenvolvimento de membranas de PVA/Colágeno aniônico como novos sistemas poliméricos de liberação controlada de antibióticos. 2019. 113 f. Tese (Doutorado) - Instituto de Química de São Carlos, Universidade de São Paulo, São Carlos, 2019.

A ceratite ulcerativa, comumente chamada úlcera ocular é uma doença muito frequente em cachorros. Embora as úlceras possam não ter uma origem microbiana, a presença de uma fissura na córnea facilita o processo infeccioso ocasionando a propagação da úlcera. Os colírios são a primeira opção terapêutica para esta doença, mas, a sua efetividade é limitada devido à produção de lágrimas, às características de barreira da córnea e ao risco de toxicidade. Dispositivos como as lentes de contato e os escudos de colágeno atuam como reservatórios que aumentam o tempo de contato entre o antibiótico e a córnea, diminuindo a frequência de administração dos colírios, melhorando assim a resposta terapêutica. Porém, estes dispositivos geralmente não são projetados para liberar antibióticos de forma continua e sua efetividade para tratar infeções oculares depende do uso de colírios como adjuvantes, com o qual não se reduz o custo do tratamento e permanece o risco de toxicidade, de desconforto para o paciente e de perda do dispositivo durante o uso (principalmente em cachorros hiperativos ou agressivos). Com o propósito de superar essas limitações, neste trabalho foram desenvolvidas e estudadas membranas de PVA/Colágeno aniônico, como novos sistemas para a liberação controlada de tobramicina, ciprofloxacina e cloranfenicol, que sejam efetivos para o tratamento da ceratite ulcerativa em cães. A partir das cinéticas de liberação in vitro, se selecionaram os melhores sistemas para a liberação controlada de antibiótico. Nos sistemas selecionados foram avaliadas as suas propriedades morfológicas, térmicas, óticas, mecânicas, antimicrobianas, além de outras propriedades físicas, como a permeabilidade ao vapor de água, o conteúdo de água, a hidrofilicidade da superfície, a solubilidade, a uniformidade, a estabilidade dimensional e o pH de superfície, para determinar assim, a sua viabilidade in vivo. Foi observado que os sistemas de liberação selecionados apresentaram as propriedades físicas adequadas, mas somente as membranas contendo ciprofloxacina atuaram como sistemas de liberação controlada com atividade bactericida contra Sthaphylococcus aureus e Escherichia coli durante 48 h, sendo materiais que podem ser usados independentemente dos colírios, para o tratamento da ceratite ulcerativa em cães. Estas membranas também têm potencial para o tratamento de outros tipos de infeções oculares e no futuro poderiam ser uteis para 0 tratamento destas doenças em pacientes humanos.

Palavras-chave: Ceratite ulcerativa, úlcera ocular, liberação controlada, ciprofloxacina, tobramicina, cloranfenicol, Sthaphylococcus aureus, Escherichia coli. 


\begin{abstract}
DAZA, Jorge Humberto Unás. Development of PVA/Anionic Collagen membranes as new polymeric controlled drug-delivery systems of antibiotics. 2019. $113 \mathrm{f}$. Tese (Doutorado) - Instituto de Química de São Carlos, Universidade de São Paulo, São Carlos, 2019.

Ulcerative keratitis, commonly known as corneal ulcer, is a common illness in dogs. Although the ulcer could not have a microbial etiology, the presence of a fissure in the cornea favors the infectious process, stimulating the ulcer progression. Antibiotic eye drops are the first line treatment for this illness, but its therapeutic effectiveness is limited by the clearance eye mechanisms, the natural ocular barriers, and the risk of toxicity. Devices such as contact lenses and corneal shields act as reservoirs that increase the contact time between the drug and the cornea, reducing the frequency of eye drop administration and then, enhancing the therapeutic effect. However, these devices are not designed to release the drug in an extended way and its effectiveness to treat ocular infections depends on the use of eye drops as adjuvants, which means that the treatment cost is not reduced and remain the risk of toxicity, patient discomfort and loss of the device (principally in fractious animals). In order to overcome these limitations, in this study, PVA/anionic collagen membranes were developed as new release systems for ciprofloxacin, tobramycin and chloramphenicol, useful to treat the ulcerative keratitis in dogs. Based on the in vitro release kinetics, were selected the better systems to release the antibiotics in a controlled and extended way. In the selected systems it was determined the morphological, thermal, optical, mechanical and antimicrobial properties, as well as other physical properties such as water vapor permeability, water content, surface hydrophilicity, solubility, uniformity, dimensional stability and $\mathrm{pH}$ of surface, in order to determine the in vivo viability of these materials. It was observed that the selected release systems have the right physical properties, but only the membranes containing ciprofloxacin act as drug controlled release systems with bactericidal activity against Staphylococcus aureus and Escherichia coli during $48 \mathrm{~h}$, and these materials can be used without eye drops to treat ulcerative keratitis in dogs. These membranes also have potential use in the treatment of other kinds of ocular infections, and in the future, they could be useful to treat these illnesses in human patients.
\end{abstract}

Keywords: Ulcerative keratitis, corneal ulcer, controlled drug release, ciprofloxacin, tobramycin, chloramphenicol, Staphylococcus aureus, Escherichia coli. 


\section{LISTA DE FIGURAS}

Figura 1 - A - Fotomicrografia da córnea canina. B - Fotomicrografia do epitélio e o estroma canino.

Figura 2 - A - Edema estromal. B - Úlcera superficial, C - Úlcera estromal e D - Descemetocelio. A coloração da fluoresceína indica a profundidade da erosão na córnea......

Figura 3 - Fómula estrutural da A - ciprofloxacina, B - tobramicina e C - cloranfenicol. .26

Figura 4 - Liberação de fármaco por intumescimento do sistema $\mathbf{A}$ - tipo reservatório e $\mathbf{B}$ - monolítico.

Figura 5 - Liberação de fármaco por degradação A - superficial e B - em massa, de um sistema matricial.

Figura 6 - Ligações em ordem crescente de labilidade com respeito à hidrólise em meio aquoso. ....33

Figura 7 - Estrutura do colágeno tipo I. A - As cadeias polipeptídicas se organizam formando uma tripla hélice denominada tropocolágeno. B - As unidades de tropocolágeno se juntam formando uma microfibrila, caracterizada por um padrão repetitivo de bandas e gaps, que se denomina 0 período D do colágeno. C - Usando um microscópio de força atômica, pode se observar o período $\mathrm{D}$ na fibrila de colágeno tipo $\mathrm{I}$.

Figura 8 - Representação esquemática da hidrólise dos agrupamentos carboxiamidas dos resíduos de asparagina e glutamina no colágeno.

Figura 9 - Fórmula molecular do PVA.

Figura 10 - Distribuição das membranas nas placas de 24 poços para o time-kill. Tempos: membranas contendo antibiótico (PVA/C24/Cpx ou PVA/C24/Tb). C+ : controle positivo de crescimento (cultura bacteriana sem antibiótico). C- : controle negativo de crescimento (cultura bacteriana contendo antibiótico à $\mathrm{CIM}$ ). $\mathrm{C} 2+$ : segundo controle positivo de crescimento contendo membrana de PVA/C24.

Figura 11 - Distribuição das membranas nas placas de 24 poços para o experimento 2. Tempos: membranas contendo antibiótico (PVA/C24/Cpx ou PVA/C24/Tb). C+ : controle positivo de crescimento (cultura bacteriana sem antibiótico).

Figura 12 - Curvas de liberação de tobramicina para as membranas de PVA/C24/GA/Tb (-) e PVA/C72/GA/Tb (-) obtidas usando a metodologia de ligação covalente.

Figura 13 - Curvas de liberação de tobramicina (-), ciprofloxacina (-) e cloranfenicol (-) para as membranas de PVA/C24/Tb (obtida por absorção de tobramicina), PVA/C24/Cpx e PVA/C24/Cfl (obtidas por mistura dos antibióticos no processo de obtenção das membranas), respectivamente.

Figura 14 - Curvas de liberação de tobramicina (-), ciprofloxacina (-) e cloranfenicol (-) para as membranas de PVA/C72/Tb (obtida por absorção de tobramicina), PVA/C72/Cpx e PVA/C72/Cfl (obtidas por mistura dos antibióticos no processo de obtenção das membranas), respectivamente.

Figura 15 - Curva de liberação de tobramicina (-), ciprofloxacina (-) para as membranas de PVA/C24/Cpx/Tb. Estes antibióticos foram incorporados por mistura no processo de obtenção das membranas.

Figura 16 - Curvas de DSC das membranas de PVA/C24 (-) e C24 (-), com uma razão de aquecimento de $10^{\circ} \mathrm{C} \mathrm{min}{ }^{-1}$, em atmosfera de nitrogênio.

Figura 17 - Espectros FTIR das membranas de PVA (-), C24 (-) e PVA/C24 (-). 
Figura 18 - Curva termogravimétrica e curva DTG das membranas de PVA (-), C24 (-) e PVA/C24 (-) em atmosfera de Nitrogênio.....

Figura 19 - Micrografias de superfície das membranas A - C24, B - PVA. C - PVA/C24 e D - PVA/C24/Tb.

Figura 20 - Micrografias de seção transversal das membranas A - C24, B - PVA, C - PVA/C24 e D - PVA/C24/Tb.

Figura 21 - Micrografias de superfície das membranas A - PVA/C24/Cpx e B - PVA/C24/Cpx após liberação da Cpx por $48 \mathrm{~h}$ em PBS.

Figura 22 - Micrografias de seção transversal das membranas A - PVA/C24/Cpx e B - PVA/C24/Cpx após liberação da Cpx por $48 \mathrm{~h}$ em PBS.

Figura 23 - Perspectiva tridimensional da topografia das membranas de A - C24, B - PVA, C - PVA/C24, D - PVA/C24/Tb, E - PVA/C24/Cpx e F - PVA/C24/Cpx após a liberação da ciprofloxacina por $48 \mathrm{~h}$ em PBS.

Figura 24 - Imagens bidimensionais da topografia das membranas de A - C24, B - PVA, C - PVA/C24, D - PVA/C24/Tb, E - PVA/C24/Cpx e F - PVA/C24/Cpx após a liberação da ciprofloxacina por 48h.

Figura 25 - Distância entre gaps para a fibrila de colágeno aniônico presente na superfície da membrana PVA/C24/Tb.

Figura 26 - Curvas de porcentagem de absorção de PBS das membranas de PVA (-), C24 (-), PVA/C24 (一), PVA/C24/Cpx (-), e PVA/C24/Tb (-)...

Figura 27 - Ângulos de contato para água nas membranas de A - PVA, B - C24, C - PVA/C24 e D - PVA/C24/Cpx, E - PVA/C24/Tb.

Figura 28 - Gráficos de A - Módulo de elasticidade, B - tensão de ruptura e C - deformação na ruptura das membranas secas.

Figura 29 - Módulo de elasticidade ( $\square$ ), a tensão de ruptura $(\square)$ e a deformação na ruptura $(\square)$ das membranas de PVA/C24/Cpx e PVA/C24/Tb intumescidas.

Figura 30 - Transmissão de luz na faixa visível do espectro luminoso (400-800nm) das membranas de PVA (一), C24 (一), PVA/C24 (-), PVA/C24/Cpx (一), e PVA/C24/Tb (一)....

Figura 31 - Membranas de A - C24, B - PVA, C - PVA/C24, D - PVA/C24/Tb e E - PVA/C24/Cpx em formato de discos de $0,5 \mathrm{~cm}^{2}$.

Figura 32 - Time-kill da bactéria S. aureus ATCC 29213 após exposição A - à ciprofloxacina (-) e à membrana de PVA/C24/Cpx (-) e B - à tobramicina (-) e à membrana de PVA/C24/Tb (-). A exposição às membranas de PVA/C24 (-) promoveu o crescimento bacteriano tanto como o controle positivo (-).

Figura 33 - Time-kill da bactéria E. coli ATCC 25922 após exposição A - à ciprofloxacina (-) e à membrana de PVA/C24/Cpx (-) e B - à tobramicina (-) e à membrana de PVA/C24/Tb (-). A exposição às membranas de PVA/C24 (-) promoveu o crescimento bacteriano tanto como o controle positivo (-).

Figura 34 - Crescimento celular de A - S. aureus e B - E. coli, após incubação de 24 horas com as membranas de PVA/C24/Cpx ( $\square$ ) e PVA/C24/Tb ( $\square$ ) incubadas previamente em PBS pelos tempos indicados. 


\section{LISTA DE TABELAS}

Tabela 1 - Eficiência na incorporação de tobramicina por ligação covalente.

Tabela 2 - Eficiência na incorporação da tobramicina, a ciprofloxacina e o cloranfenicol por absorção nas membranas de PVA/C24. A diferença entre as porcentagens de incorporação de cada antibiótico para os diferentes tempos de imersão não foi estatisticamente significativa $(p>0,05)$

Tabela 3 - Eficiência na incorporação da tobramicina, a ciprofloxacina e o cloranfenicol por absorção nas membranas de PVA/C72. A diferença entre as porcentagens de incorporação de cada antibiótico para os diferentes tempos de imersão não foi estatisticamente significativa $(p>0,05)$

Tabela 4 - Eficiência na incorporação de ciprofloxacina e cloranfenicol por mistura durante a obtenção das membranas.

Tabela 5 - Porcentagem de antibiótico liberado pelas membranas depois de $96 \mathrm{~h}$ em PBS.

Tabela 6 - Coeficiente de determinação para cada modelo de liberação de fármaco .

Tabela 7 - Eventos térmicos e porcentagens de perda de massa correspondentes aos estágios de degradação térmica das membranas de C24, PVA e PVA/C24 .

Tabela 8 - Valores de rugosidade média $\left(R_{a}\right)$ e Desvio médio quadrático $\left(R_{q}\right)$ para as membranas, calculados para uma área superficial de $25 \mu \mathrm{m}^{2}$.

Tabela 9 - Conteúdo de água das membranas, a córnea, escudos de colágeno e lente de contato macia Biofinity ${ }^{\circledR}$.

Tabela 10 - Valores de PV e TPV para as membranas

Tabela 11 - Solubilidade das membranas após $48 \mathrm{~h}$ de imersão em PBS a $37^{\circ} \mathrm{C}$

Tabela 12 - Massa e dimensões das membranas de PVA/C24/Cpx e PVA/C24/Tb em formato de discos de $0,5 \mathrm{~cm}^{2}$

Tabela 13 - Concentração Inibitória Mínima para Ciprofloxacina …..................................................8

Tabela 14 - Concentração Inibitória Mínima para Tobramicina .............................................................88

Tabela 15 - Taxa de liberação teórica de um disco de PVA/C24/Cpx de $0,5 \mathrm{~cm}^{2}$ na superfície ocular. Estes valores foram calculados tendo em conta que a taxa de produção de lágrimas é $1 \mu \mathrm{g} \mathrm{mL}^{-1}$ 


\section{ABREVIATURAS}

AFM: Microscopia de força atômica

BHI: Brain-Heart Infusion

C24: Membranas de colágeno aniônico com hidrólise alcalina de 24 h

C72: Membranas de colágeno aniônico com hidrólise alcalina de 72 h

CIM: Concentração inibitória mínima

COL: Colágeno

COL24: Colágeno de tendão bovino hidrolisado por $24 \mathrm{~h}$ em solução alcalina

COL72: Colágeno de tendão bovino hidrolisado por 72 h em solução alcalina

Cfl: Cloranfenicol

Cpx: Ciprofloxacina

DNFB: Dinitrofluorbenzeno

DSC: Calorimetria Diferencial de Varredura

DTG: Termogravimetria derivada

EDC: 1-etil-3-(3-dimetilaminopropil) carbodiimida

EDTA: Ácido etilenodiamino tetra-acético

FTIR: Espectroscopia no Infravermelho com transformada de Fourier

HEMA: 2-hidroxietilmetacrilato

MHCA: Mueller Hinton Cátion Ajustado (caldo de cultura)

MMP: Metaloproteinases

NHS: N-hidroxisuccinimida

PBS: tampão fosfato salino

PGA: Poli(ácido glicólico)

PHEMA: poli(2-hidroxietilmetacrilato)

PLA: Poli(ácido láctico) 
PLGA: ácido láctico-co-ácido glicólico

PMMA: polimetilmetacrilato

PV: Permeabilidade ao vapor de água

PVA: Poli(álcool vinílico)

PVA/C24: Membranas de PVA e colágeno aniônico com hidrólise alcalina de $24 \mathrm{~h}$

PVA/C24/Cfl: Membranas de PVA e colágeno aniônico com hidrólise alcalina de

$24 \mathrm{~h}$ contendo cloranfenicol

PVA/C24/Cpx: Membranas de PVA e colágeno aniônico com hidrólise alcalina de $24 \mathrm{~h}$ contendo ciprofloxacina.

PVA/C24/GA/Tb: Membranas de PVA e colágeno aniônico com hidrólise alcalina de $24 \mathrm{~h}$, reticuladas com glutaraldeido e contendo tobramicina ligada covalentemente PVA/C24/Tb: Membranas de PVA e colágeno aniônico com hidrólise alcalina de $24 \mathrm{~h}$ contendo tobramicina.

PVA/C24/Cpx/Tb: Membranas de PVA e colágeno aniônico com hidrólise alcalina de $24 \mathrm{~h}$ contendo ciprofloxacia e tobramicina simultaneamente

PVA/C72: Membranas de PVA e colágeno aniônico com hidrólise alcalina de $72 \mathrm{~h}$ PVA/C72/Cfl: Membranas de PVA e colágeno aniônico com hidrólise alcalina de $72 \mathrm{~h}$ contendo cloranfenicol

PVA/C72/Cpx: Membranas de PVA e colágeno aniônico com hidrólise alcalina de $72 \mathrm{~h}$ contendo ciprofloxacina

PVA/C72/GA/Tb: Membranas de PVA e colágeno aniônico com hidrólise alcalina de $72 \mathrm{~h}$, reticuladas com glutaraldeido e contendo tobramicina ligada covalentemente PVA/C72/Tb: Membranas de PVA e colágeno aniônico com hidrólise alcalina de $72 \mathrm{~h}$ contendo tobramicina

$\mathbf{R}_{\mathbf{a}}$ : Rugosidade meia

$\mathbf{R}_{\mathbf{q}}$ : Desvio meio quadrático

Tb: Tobramicina

TPV: Taxa de permeabilidade ao vapor de água 
TGA: Análise termogravimétrica

UFC: Unidades formadoras de colônias

Ф: Ângulo de contato 


\section{SUMÁRIO}

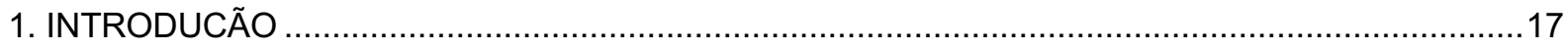

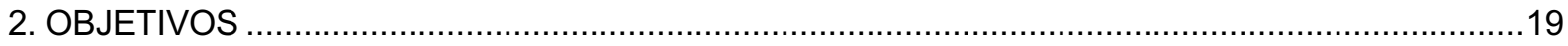

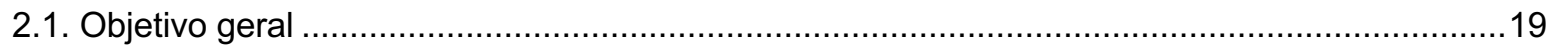

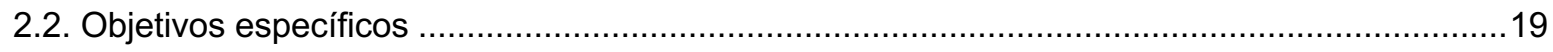

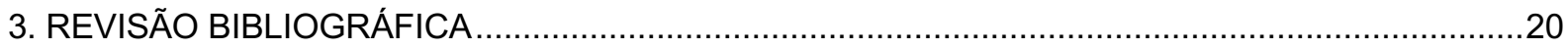

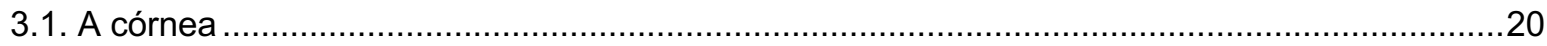

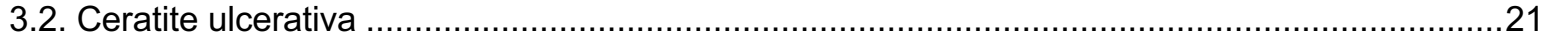

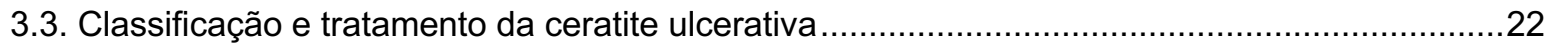

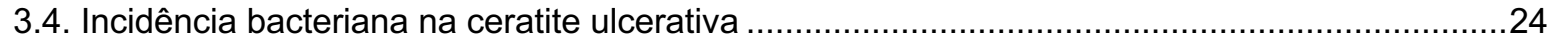

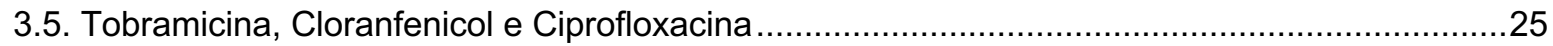

3.6. Rotas de administração de fármacos para o tratamento da ceratite ulcerativa .........................27

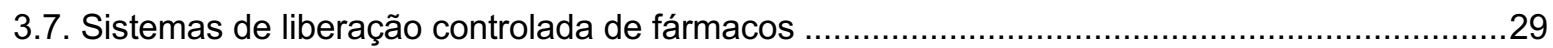

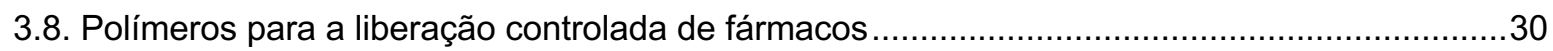

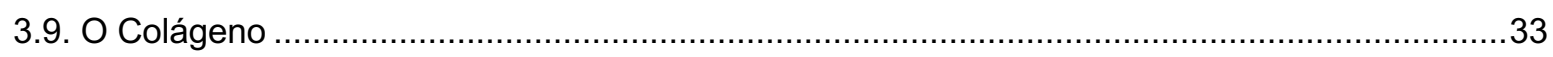

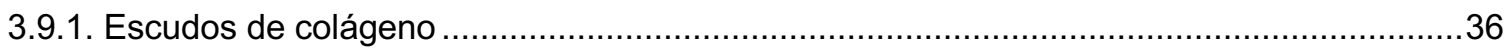

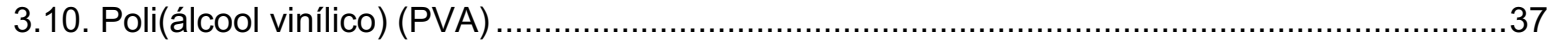

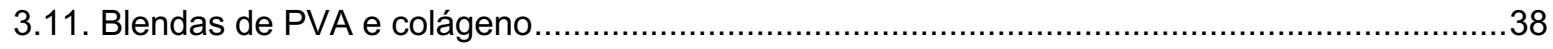

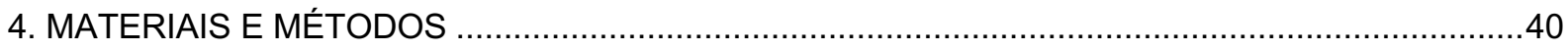

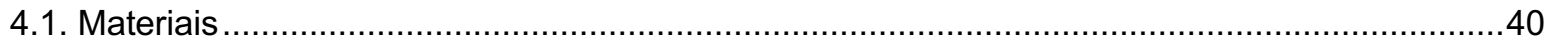

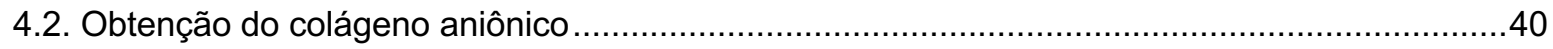

4.3. Obtenção das membranas de PVA/colágeno aniônico ............................................................40

4.4. Obtenção de membranas de referência .............................................................................. 41

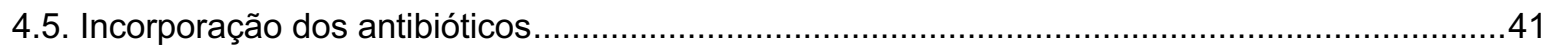

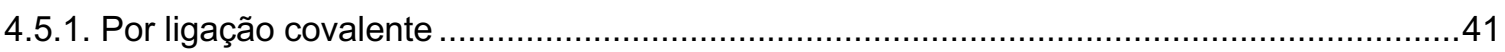

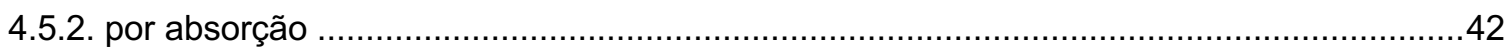

4.5.3. Por mistura no processo de obtenção das membranas ....................................................... 42

4.6. Determinação do conteúdo de antibiótico incorporado nas membranas ...................................43

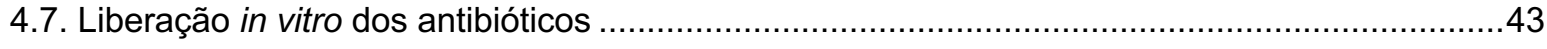

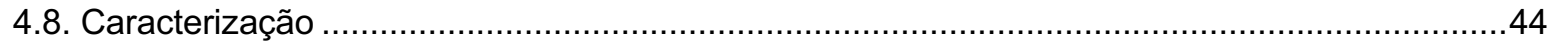

4.8.1. Espectroscopia no Infravermelho com transformada de Fourier (FTIR) ...........................44

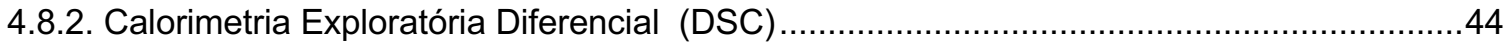

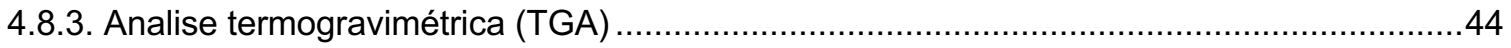

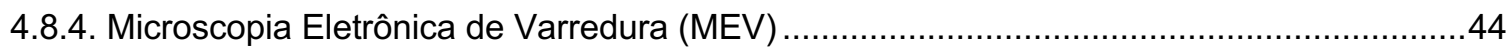


4.8.5. Microscopia de Força atômica (AFM)

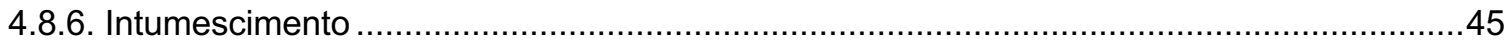

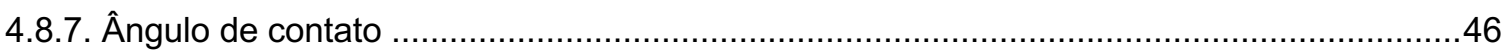

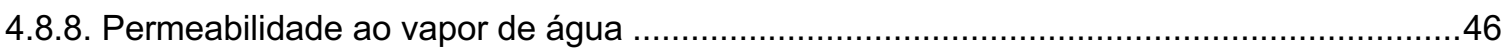

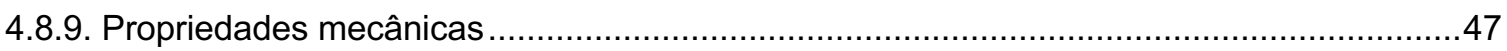

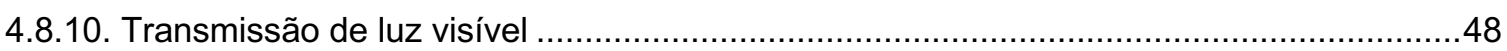

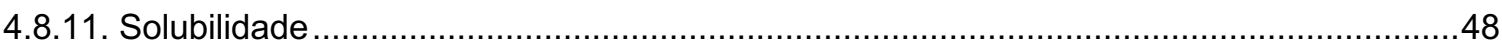

4.8.12. Uniformidade e estabilidade de forma das membranas............................................. 48

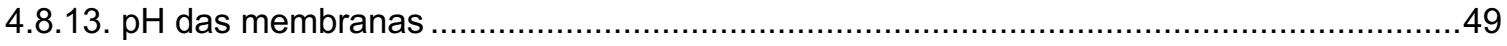

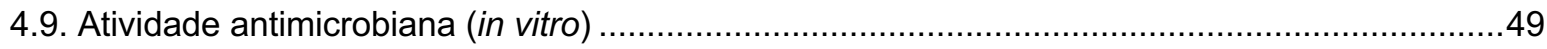

4.9.1.Concentração inibitória mínima (CIM) dos antibióticos ..................................................... 49

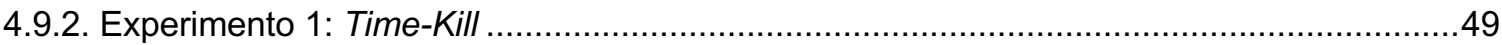

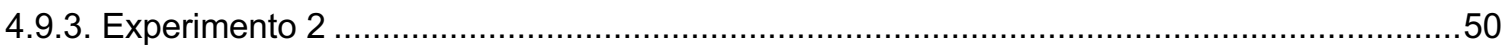

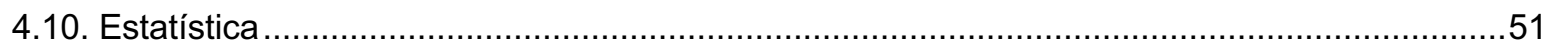

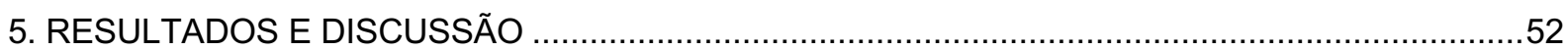

5.1. Obtenção das membranas de PVA/colágeno aniônico...............................................................52

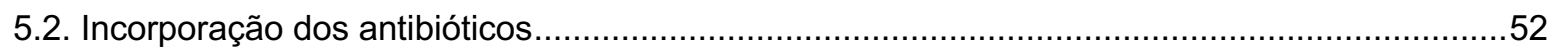

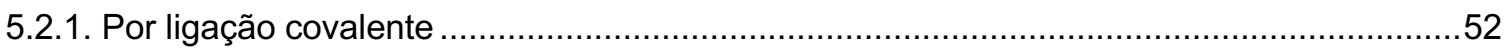

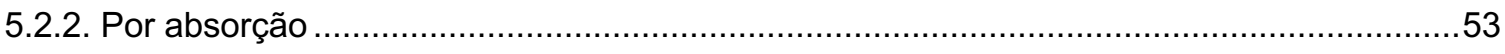

5.2.3. Por mistura no processo de obtenção das membranas ...................................................54

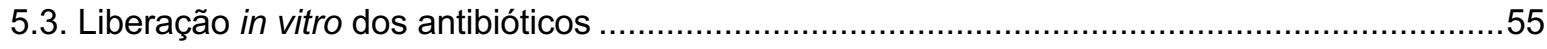

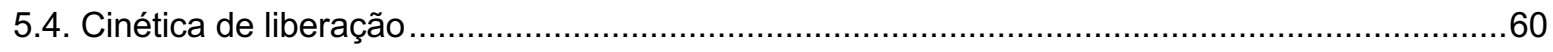

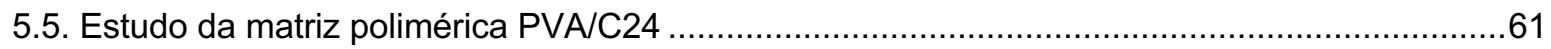

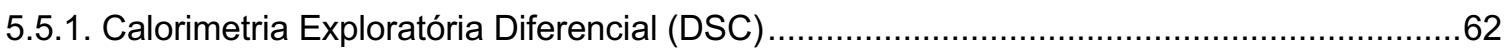

5.5.2. Espectroscopia no Infravermelho com transformada de Fourier (FTIR) ...........................63

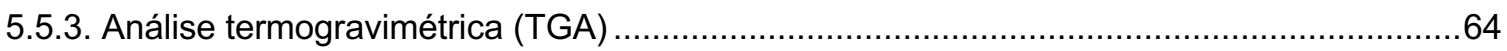

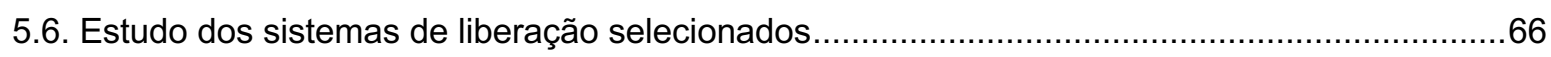

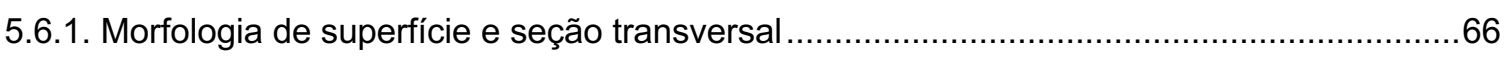

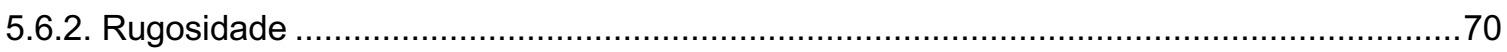

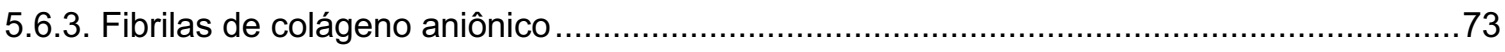

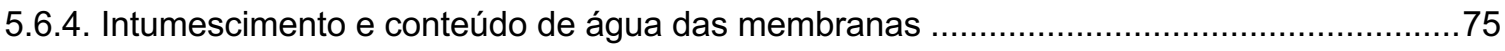

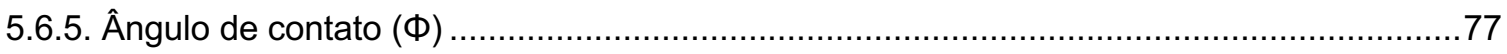

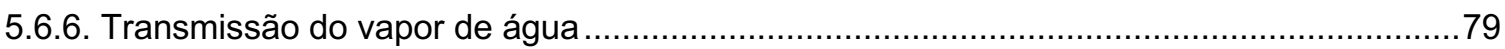

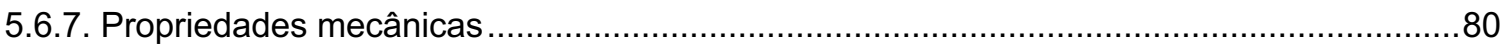


5.6.8. Transmissão de luz visível

5.6.9. Solubilidade do material

5.6.10. Uniformidade e estabilidade de forma das membranas .86

5.6.11. $\mathrm{pH}$ das membranas .87

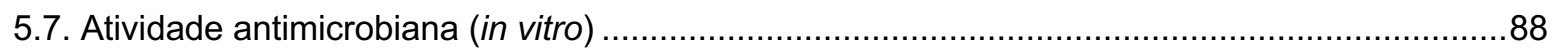

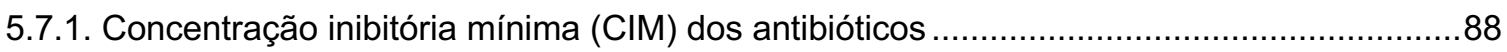

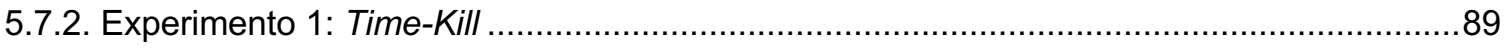

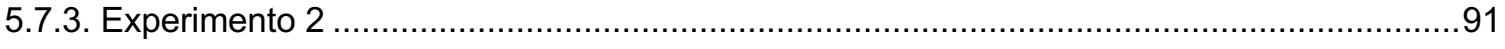

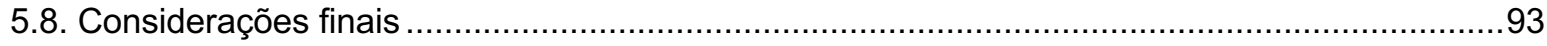

6. CONCLUSÃO

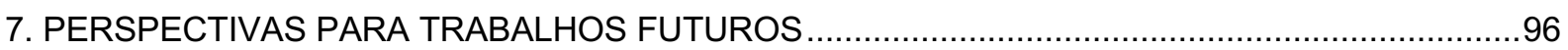

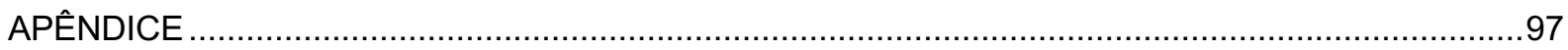

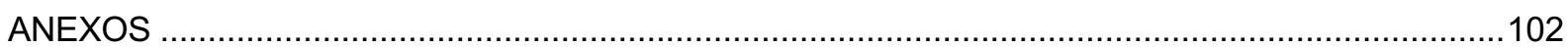

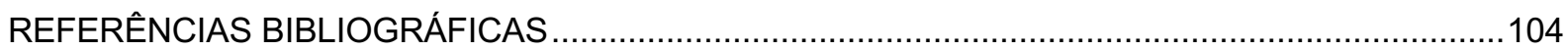




\section{INTRODUCÃO}

A úlcera ocular é uma doença muito frequente em animais domésticos, especialmente cachorros. As úlceras oculares caracterizam-se pela perda do epitélio e a ativação de fibroblastos que ocasionam a inflamação do estroma e a infiltração de células inflamatórias, com a posterior perda da transparência e integridade da córnea (SUZUKI et al., 2003). Quando as úlceras são infectadas por microrganismos, o processo de recuperação é retardado, podendo-se apresentar endoftalmite ou glaucoma (GELATT, 2014). Portanto, o tratamento com antibióticos deve ser iniciado quando a úlcera ocular for diagnosticada (PRADO et al., 2006).

Geralmente, o tratamento das úlceras oculares consiste no uso de uma associação de antibióticos para melhorar o espectro de ação. Entre os antibióticos comumente usados em formulações oftálmicas estão a neomicina, bacitracina e polimixina $\mathrm{B}$. Mas, quando a úlcera é do tipo colagenolítica os fármacos escolhidos são a gentamicina, a tobramicina, a ciprofloxacina, o cloranfenicol e a amikacina (PRADO et al., 2006; GELATT, 2014).

Geralmente a administração desses antibióticos ocorre através de formulações convencionais como colírios, géis ou cremes, que oferecem um tempo de vida média curto para a ação do fármaco.

As lentes de contato e os escudos de colágeno atuam como sistemas de liberação que ajudam a prolongar o efeito do colírio, por aumento do tempo de contato entre o fármaco e a córnea, reduzindo assim a frequência de dosagem e consequentemente a incidência de toxicidade. Porém, estes dispositivos, apresentam limitações práticas que reduzem sua eficiência. Por exemplo, as lentes de contato podem apresentar adesão microbiana e seu uso contínuo gerar desconforto para o paciente (WILLOUGHBY; BATTERBURY; KAYE, 2002). Por outro lado, os escudos de colágeno devem ser substituídos frequentemente por pessoa capacitada, o que eleva o custo do tratamento, aumenta o desconforto do paciente e limita seu uso terapêutico a condições não crônicas. Ademais, por não serem transparentes reduzem a visão do paciente (WILLOUGHBY; BATTERBURY; KAYE, 2002). Tanto as lentes de contato, como os escudos de colágeno geralmente não são projetados para oferecer uma liberação continua de fármaco e por isso são usados junto com os colírios, o que mantém presente o risco de toxicidade, desconforto para o paciente e possível perda do dispositivo durante o tratamento. 
O desenvolvimento de um biomaterial adequado para o tratamento das úlceras oculares é uma tarefa desafiante. O biomaterial usado deve ser permeável ao oxigênio para evitar a necrose do epitélio, bioestável, biocompatível, não deve permitir a adesão de proteínas presentes no fluido lacrimal nem a adesão de microrganismos, deve ter resistência mecânica para suportar situações de estresse durante o processamento, manuseio e aplicação, e deve ser preferivelmente transparente (JIANG et al., 2014; LIU et al., 2016). A exigência do material aumenta se ele também tiver que atuar como um sistema de liberação de fármacos, pois o material deve liberar o fármaco nas concentrações suficientes no local afetado e prevenir uma infecção secundária. Além disso, o dispositivo deve ocasionar o menor desconforto para o paciente.

No presente estudo foram desenvolvidas membranas de PVA e colágeno aniônico que possam serem usadas como novos sistemas de liberação de tobramicina, ciprofloxacina e cloranfenicol, e que, além disso, tenham as propriedades físicas adequadas para ser usados no tratamento da úlcera ocular canina.

O colágeno é um polímero natural, abundantemente presente em tecidos animais como a córnea. Além de servir como matriz para a liberação de fármacos o colágeno favorece o processo de regeneração da córnea (WILLOUGHBY; BATTERBURY; KAYE, 2002). Por outro lado, o PVA, é um polímero sintético não tóxico e extensamente usado em oftalmologia. Quando associado ao colágeno, ele apresenta significativas melhora nas propriedades mecânicas e ópticas (KANUNGO et al., 2013). O esperado é que as membranas obtidas a partir destes dois polímeros, tenham um efeito duplo. Por um lado cria uma barreira de proteção e fixação de colagenases para evitar a propagação da ulcera e, por outro, fornece de forma controlada e continua as concentrações terapêuticas de cada fármaco para evitar a proliferação microbiana no olho e favorecer a regeneração da córnea.

Este trabalho se iniciou como uma parceria com o Professor Dr. Alexandre Lima de Andrade (Faculdade de Medicina Veterinária - FMVA, UNESP, campus de Araçatuba), quem será responsável pelo desenvolvimento dos testes in vivo das membranas elaboradas. 


\section{OBJETIVOS}

\subsection{Objetivo geral}

Desenvolver membranas de PVA/Colágeno como novos sistemas de liberação controlada de tobramicina, ciprofloxacina e cloranfenicol, antibióticos que são efetivos no tratamento da ceratite ulcerativa canina.

\subsection{Objetivos específicos}

A - Obter membranas de PVA/Colágeno contendo cada um dos antibióticos, que possuam as propriedades mecânicas necessárias para seu processamento, manuseio e implementação no tratamento da úlcera ocular canina.

B - Avaliar a cinética de liberação in vitro de cada um dos fármacos, visando a seleção de sistemas de liberação controlada efetivos no tratamento da úlcera canina.

C -Determinar e analisar as propriedades físicas e químicas dos sistemas de liberação selecionados e das matrizes poliméricas usadas para fabricá-los.

D - Estudar as características morfológicas dos sistemas de liberação de fármacos selecionados, antes e depois da liberação do antibiótico, através de técnicas de imagem como a microscopia eletrônica de varredura e a microscopia de força atômica para relacionar essas características às propriedades físicas destes sistemas.

E - Determinar a atividade antimicrobiana in vitro dos sistemas de liberação de fármacos selecionados, contra alguns microrganismos de incidência comum na infeção associada à úlcera ocular canina, como por exemplo Pseudomonas aeruginosa, Staphylococcus aureus e Escherichia coli. 


\section{REVISÃO BIBLIOGRÁFICA}

\subsection{A córnea}

$\mathrm{Na}$ região frontal do olho encontra-se a córnea, um tecido colagenoso transparente que cobre uma sexta parte da superfície ocular, e cuja função é proteger os tecidos internos do olho e permitir a passagem de luz até a retina, para que aconteça o processo visual. A córnea carece de irrigação sanguínea (não vascularização) portanto, o aporte de nutrientes e oxigênio ocorre através do fluxo lacrimal e o humor aquoso.

Estruturalmente a córnea é um conjunto de cinco camadas: o epitélio; a membrana de Bowman (ausente em cachorros); o estroma, que é uma camada colagenosa com um alto conteúdo de fibroblastos; a membrana de Descemet e o endotélio (Figura 1).

Figura 1 - A - Fotomicrografia da córnea canina. B - Fotomicrografia do epitélio e o estroma canino.

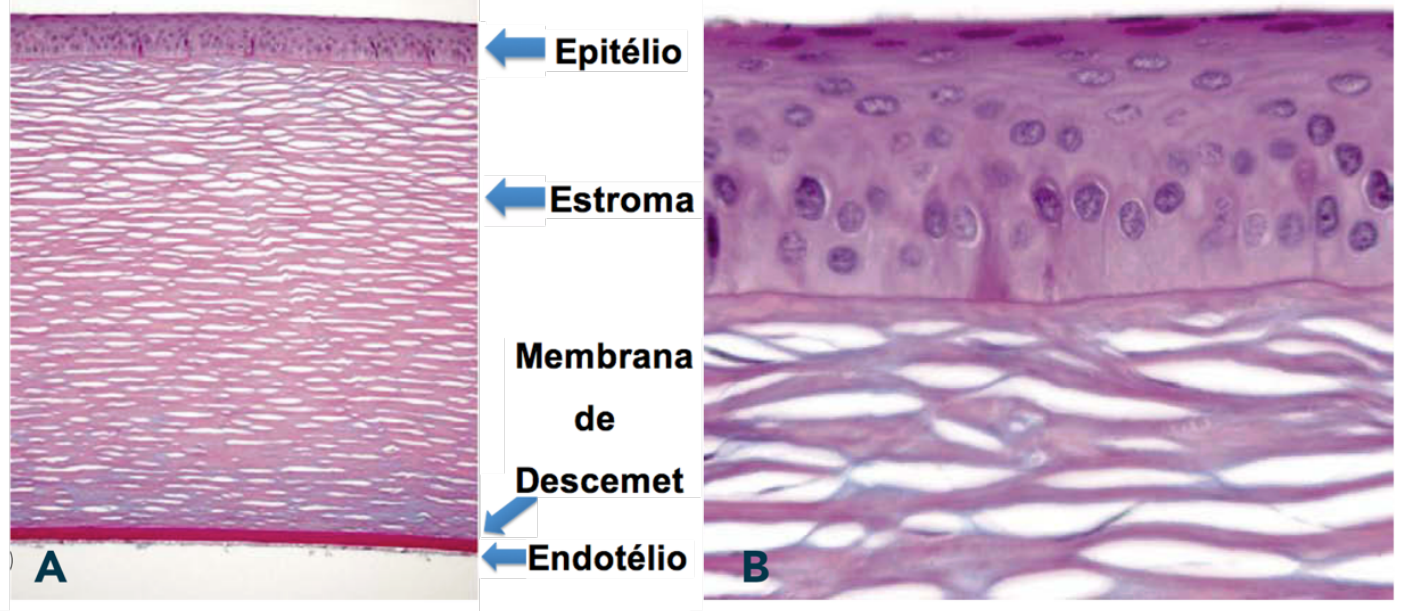

Fonte - DUBIELZIG et al., 2010

O epitélio é camada tecidual mais externa da córnea. Esta camada é composta por sua vez por 5-7 camadas de células o que faz dela uma estrutura fina com uma espessura de uns 25-40 $\mu \mathrm{m}$ em cachorros e 50-100 $\mu \mathrm{m}$ em humanos (LLOYD; FARAGHER; DENYER, 2001; GELATT, 2014). O epitélio tem uma alta capacidade regenerativa em resposta a ferimentos, com um ciclo de divisão, migração e substituição celular de aproximadamente 4-8 dias, similar ao observado na epiderme. A disposição celular compacta do epitélio e a presença de domínios hidrofóbicos fazem dele uma barreira eficiente contra agentes externos, como 
patógenos, detritos, substâncias corrosivas e inclusive fármacos (RATHORE; NEMA, 2009; DUBIELZIG et al., 2010).

Separado do epitélio por uma fina estrutura chamada de membrana de Bowman está o estroma, que é constituído por um arranjo uniforme de lamelas de colágeno empilhadas umas sobre outras e paralelas à superfície do olho. O estroma constitui quase um $90 \%$ do volume total da córnea e sua estrutura lamelar aporta resistência mecânica ao mesmo tempo em que permite conservar a transparência da córnea (LLOYD; FARAGHER; DENYER, 2001). Através do estroma podem difundir sustâncias hidrofílicas com facilidade devido a sua estrutura não ser compacta como a do epitélio.

O endotélio, a camada mais interna da córnea, contribui para manter a correta hidratação do estroma, e portanto, sua transparência. Consiste em uma única camada plana de células hexagonais ( $5 \mu \mathrm{m}$ de altura e $20 \mu \mathrm{m}$ de largura) o endotélio está separado do estroma pela membrana de Descemet e em contato direto com o humor aquoso permitindo o transporte passivo de água até o estroma (RATHORE; NEMA, 2009).

\subsection{Ceratite ulcerativa}

A ceratite ulcerativa é uma das doenças oculares mais frequentes em animais domésticos, e uma das principais causas de cegueira em cachorros (KIM; WON; SOON-WUK, 2009). Este tipo de inflamação da córnea caracteriza-se pela presença de uma erosão ou fissura que pode afetar tanto uma fração da córnea, como a córnea inteira e pode estar acompanhada de edema, vascularização, dor intensa e fotofobia (STARTUP, 1984). Frequentemente se originam por trauma e embora inicialmente não apresentem infeção, as úlceras oculares são rapidamente contaminadas por microrganismos.

Outros fatores como a produção anormal de lágrimas, desequilíbrio fisiológico, problemas congênitos ou iatrogênicos, anormalidades na forma e função das pálpebras podem dar origem a uma ceratite ulcerativa (VONGSAKUL et al., 2009).

Os sintomas desta doença são geralmente dor, lacrimejamento excessivo, visão embaçada, olhos vermelhos, fotofobia, sensação de corpo estranho e blefaroespasmo (NITHYA; BHASKAR, 2013). 


\subsection{Classificação e tratamento da ceratite ulcerativa}

As úlceras oculares classificam-se pelo grau de profundidade da fissura dentro da córnea, como úlceras superficiais, úlceras estromais profundas, descemetocelio e úlceras perfurantes (OLLIVIER, 2003). Na prática clínica é mais comum classificar as úlceras como: ulceração simples, quando cicatriza em menos de 7 dias e sem incidência de alguma infecção ou complicação maior; ulceração complicada, quando o ferimento persiste por mais de 7 dias ocorrendo infecção ou outra patologia e ulceração progressiva quando o ferimento atinge uma grande extensão da córnea (MAGGS; MILLER; OFRI, 2008; JHANJI et al., 2011).

O diagnóstico de uma úlcera ocular é feito por coloração com fluoresceína sódica $2 \%$. Instilado na superfície ocular, este corante de caráter hidrofílico passa através do epitélio danificado e interage com o estroma dando uma coloração verde brilhante que evidencia a magnitude da úlcera ocular (GELATT, 2014).

Qualquer dano no epitélio ou no endotélio pode afetar a hidratação normal da córnea originando opacidade ou edema (Figura 2A) (MAGGS; MILLER; OFRI, 2008). As úlceras superficiais (Figura 2B) afetam principalmente o endotélio e geralmente curam em poucos dias com pouca formação de cicatriz, mas em alguns casos podem ser persistentes e reaparecer.

As úlceras estromais (Figura 2C) têm uma maior incidência de contaminação por bactérias do que as superficiais. Este tipo de úlcera pode ser classificado por sua vez como úlcera estromal não progressiva e úlcera estromal progressiva. No caso da primeira o tratamento é similar ao tratamento para as úlceras superficiais, com provável intervenção cirúrgica (enxertos ou retalhos conjuntivais) (GELATT, 2014). Por outro lado, as úlceras estromais progressivas quase sempre são infectadas e constituem um grande risco para a visão do paciente. A progressividade destas úlceras pode ocasionar desde uma deficiência visual até a perda total do olho por complicações maiores como endoftalmite, glaucoma ou tísica bulbar. Devido à alta incidência de infecção, a úlcera estromal progressiva requer um tratamento muito agressivo com antibióticos, os quais são selecionados a partir dos resultados de culturas microbianas, testes citológicos e de suscetibilidade. Entre os procedimentos cirúrgicos usados para tratar essas úlceras progressivas estão os enxertos e retalhos subconjuntivais e as ceratoplastias (OLLIVIER, 2003). 
Figura 2 - A - Edema estromal. B - Úlcera superficial, C - Úlcera estromal e D - Descemetocelio. A coloração da fluoresceína indica a profundidade da erosão na córnea.

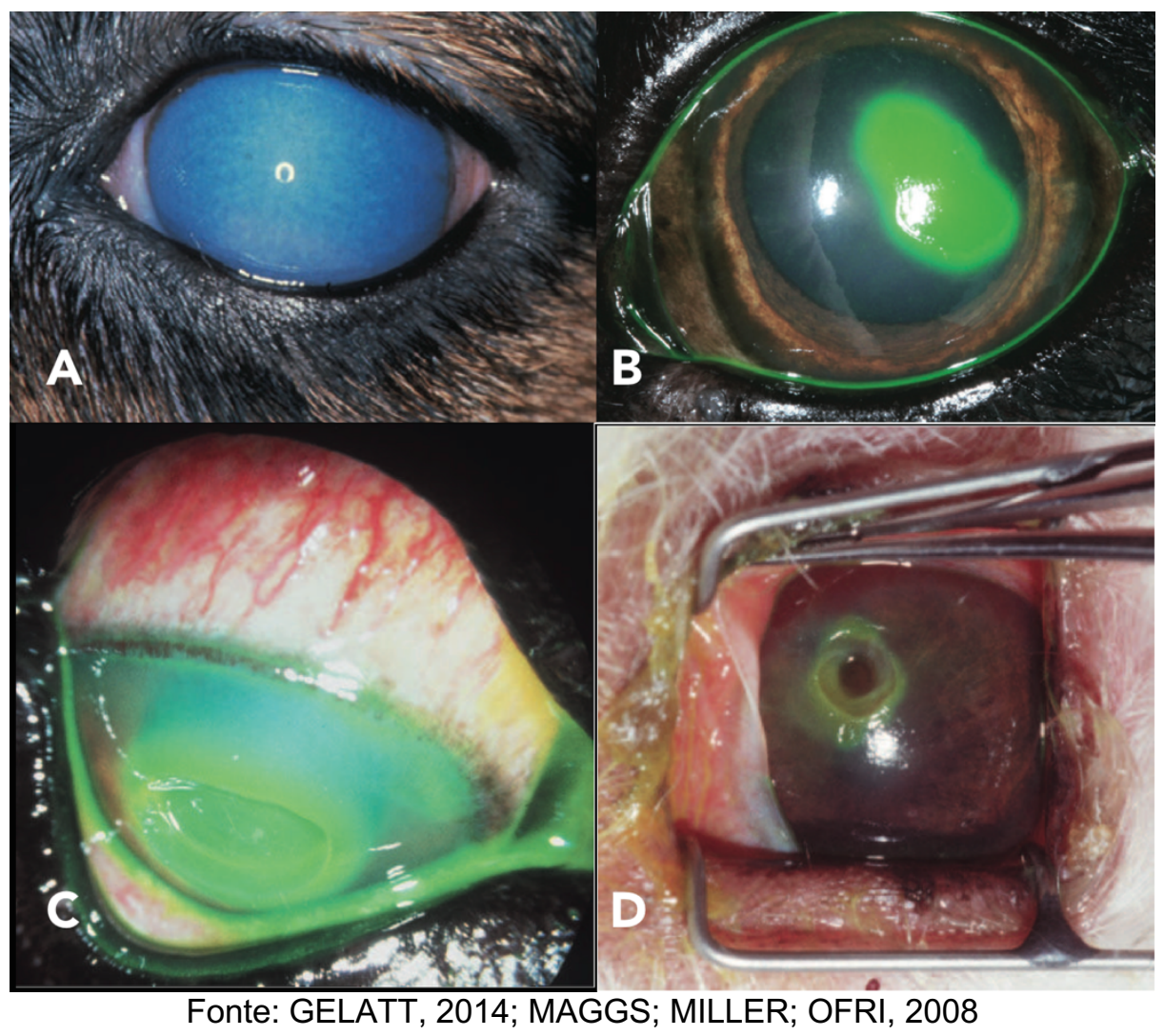

A progressão de uma úlcera estromal é estimulada por um desbalanço nos mecanismos que atuam na regeneração normal da córnea. Células inflamatórias são produzidas para ajudar na remoção do tecido danificado e permitir a regeneração do estroma. Estas células junto com as células epiteliais e os fibroblastos atuam produzindo colagenases e outras proteases, tais como, as metaloproteinases (MMP) MMP2 e MMP9 e serina proteases, que têm a capacidade de degradar a matriz extracelular da córnea (WILLOUGHBY; BATTERBURY; KAYE, 2002). Mas alguns tecidos como a córnea contém inibidores para essas MMP e serina proteases que evitam a destruição excessiva do estroma (OLLIVIER et al., 2007). Algumas bactérias como $P$. aeruginosa produzem proteases que contribuem para o desequilíbrio que favorece a ação destas enzimas com respeito a seus inibidores. O resultado disso é a rápida degradação da córnea característica das úlceras estromais progressivas (HYNDIUK, 1981).

O "melting" é um estado avançado das úlceras estromais progressivas caracterizado pela rápida dissolução do estroma e risco de perfuração da córnea 
(algumas vezes até em $24 \mathrm{~h}$ ). O sucesso no tratamento das úlceras em melting consiste em controlar rapidamente a infecção associada e inibir a ação das colagenases e proteases (MCELVANNEY, 2003). Para isso, geralmente se requer um tratamento tópico vigoroso com antibióticos de amplo espectro (cada 1-2 h), atropina e inibidores de proteases. A tobramicina, a gentamicina e a ciprofloxacina são alguns dos antibióticos inicialmente selecionados de forma empírica para o tratamento destas úlceras até obter os resultados de culturas microbianas, após o qual, o tratamento pode ser modificado para atingir o agente patógeno especifico (GELATT, 2014). Entre os inibidores de proteases são usados o soro autólogo, o EDTA e tetraciclinas (MCELVANNEY, 2003).

$\mathrm{O}$ descemetocelio (Figura 2D) caracteriza-se pela destruição total do epitélio e o estroma. $O$ caso da úlcera perfurante é o mais grave, pois a barreira constituída pela membrana de Descemet e o endotélio está quebrada e ocorre perda do humor aquoso com possível prolapso do íris (MAGGS; MILLER; OFRI, 2008). O tratamento de uma perfuração da córnea deve ser imediato para conservar a integridade da córnea e evitar a aparição de glaucoma ou endoftalmite. A seleção do tratamento adequado depende da localização, tamanho da perfuração e o estado da doença, e pode requerer desde o uso de lentes de contato de bandagem até um transplante de córnea (GELATT, 2014).

\subsection{Incidência bacteriana na ceratite ulcerativa}

As pálpebras e o fluido pré-corneal protegem a superfície ocular e evitam a colonização do epitélio por microrganismos patógenos (SCHAEFER et al., 2001). No entanto, patógenos oportunistas podem invadir rapidamente a córnea ante a presença de uma fissura ou úlcera na superfície ocular (JHANJI et al., 2011).

A seleção de um tratamento adequado para a ceratite ulcerativa é baseado na preparação de culturas bacterianas, testes de citotoxicidade e testes de susceptibilidade microbiana (WHITLEY, 2000). Porém, a maioria das vezes estes procedimentos não são aplicados, devido por um lado, ao custo que representam para o dono do animal, e por outro lado, que este tipo de testes são demorados e na maioria das vezes o tratamento deve ser iniciado prontamente para evitar a rápida propagação da úlcera. Nestes casos, a seleção dos antibióticos é baseada no seu espectro de ação e no conhecimento dos microrganismos de incidência comum na região geográfica do paciente (GELATT, 2014). 
Embora a incidência de patógenos varie de uma zona geográfica para outra, as bactérias representam entre o 65 e $90 \%$ de todos os casos de ceratites (NITHYA; BHASKAR, 2013) e entre estas, as linhagens comumente identificadas nas úlceras oculares de cães e gatos são Staphylococcus aureus, Pseudomonas aeruginosa e Streptococcus spp (CALLEGAN; O'CALLAGHAN; HILL, 1994). Outros tipos de bactérias como Klebsiella pneumoniae, Escherichia coli, Bacillus spp, e Enterobacter aerogenes também são frequentemente encontrados, porém em menor proporção (PRADO et al., 2006; TOLAR et al., 2006).

Entre as bactérias comentadas, $S$. aureus e $P$. aeruginosa tem recebido especial atenção devido a que quando infectam a úlcera ocular, favorecem o melting do stroma. S. aureus é um coco Gram-positivo presente naturalmente na flora do rosto. Esta bactéria produz toxinas citolíticas capazes de destruir as membranas celulares e leucócitos polimorfonucleares (PMN) (IANDOLO, 1989). Em modelos animais este microrganismo ocasionou a perfuração da córnea de coelhos em um dia (CALLEGAN et al., 1992). Por outro lado, P. aeruginosa é um bacilo Gramnegativo que produz uma variedade de proteases, tais como a elastase $A$, a elastase $B$ e proteases alcalinas que destroem a matriz extracelular do estroma, ocasionando a opacidade da córnea e alto risco de perfuração caso não se aplique o tratamento prontamente (HOBDEN, 2002; JHANJI et al., 2011).

\subsection{Tobramicina, Cloranfenicol e Ciprofloxacina}

A tobramicina, o cloranfenicol e a ciprofloxacina (Figura 3) são antibióticos frequentemente empregados para o tratamento de uma variedade de infecções oculares. O uso desses antibióticos é indicado para o tratamento das úlceras oculares progressivas (incluindo as úlceras em melting), devido a seu amplo espectro de ação, que inclui bacilos Gram-negativos como Pseudomonas aeruginosa e cocos Gram-positivos como Staphylococcus e Streptococcus spp (GELATT, 2014). 
Figura 3 - Fórmula estrutural da A - ciprofloxacina, B - tobramicina e C - cloranfenicol.
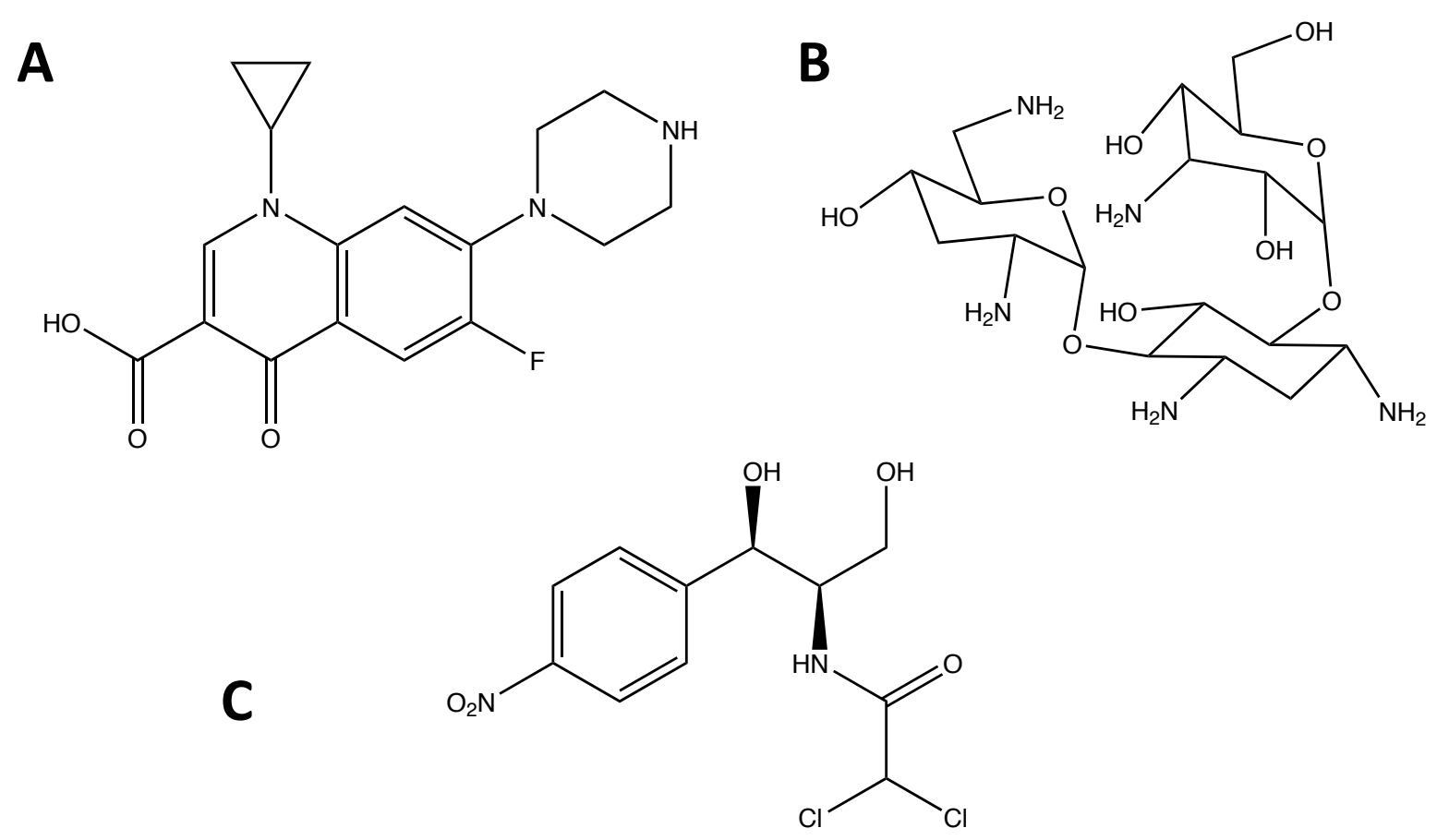

Fonte - KIKUCHI et al., 2017; LIU et al., 2014; PUOCl et al., 2012

A tobramicina é um aminoglicosídeo frequentemente usado para tratar a ceratite bacteriana. O efeito bactericida deste antibiótico é amplo, particularmente contra bacilos Gram-negativos. No entanto, o uso da tobramicina é limitado devido a incidência de toxicidade na córnea (SUEKE et al., 2013). As flouroquinolonas como a ciprofloxacina também têm um amplo espectro de ação contra bacilos Gramnegativos (com moderada atividade contra $S$. aureus e espécies de Streptococcus) e com uma baixa toxicidade ocular (THOMPSON, 2007). O cloranfenicol tem amplo espectro de ação contra bactérias Gram-positivas e Gram-negativas (não efetivo contra $P$. aeruginosa). Este antibiótico apresenta uma alta penetração intraocular e seu uso tópico ainda não foi associado com toxicidade ocular (LAM et al., 2002). O uso desses três antibióticos demostrou ser efetivo contra 33 isolados bacterianos (80,7\% Gram-negativos e 19,3\% Gram-positivos) obtidos a partir de 19 cachorros com úlceras oculares na cidade de Fortaleza, Ceará; sendo essa distribuição bacteriana, similar à obtida em São Paulo (PRADO et al., 2006).

Geralmente estes antibióticos são administrados de forma tópica através de colírios, géis ou cremes com uma frequência que depende da severidade da úlcera e a potência do antibiótico. No caso de úlceras progressivas o paciente 
geralmente requer uma administração muito frequente e intensa destes antibióticos para evitar a rápida perfuração e posterior perda do olho, chegando a ser necessária a supervisão de um corpo clinico treinado para a dosagem do antibiótico, com o qual se eleva o custo de tratamento além de aumentar a incidência de efeitos secundários para o paciente (O'BRIEN, 2003).

Alguns sistemas de liberação controlada destes antibióticos têm sido desenvolvidos empregando polímeros como goma xantana (em colírio para a liberação de tobramicina) (KUNO; FUJII, 2011), gelatina (em implante para a liberação de ciprofloxacina) (MUNDADA; SHRIKHANDE, 2008), policaprolactona, ácido láctico-co-ácido glicólico (PLGA) e poli-hidroxietil metacrilato (em lentes para a liberação de ciprofloxacina) (CIOLINO et al., 2009; GARHWAL et al., 2012), poli(acetato de vinilo), hidroxipropilmetilcelulose (KHOKHAR, 2015) e quitosana (em implantes para a liberação de cloranfenicol) (CHANG et al., 2007).

\subsection{Rotas de administração de fármacos para o tratamento da ceratite} ulcerativa

O olho é uma via complexa para a administração de fármacos no tratamento de doenças. Enquanto as metodologias de administração oral e transdérmica conseguem levar o fármaco até o sistema circulatório, a administração de fármacos no olho, geralmente, serve para tratar doenças localizadas in situ ou nas proximidades. O olho apresenta barreiras estáticas e dinâmicas para a administração de fármacos o que limita a ação terapêutica desses compostos (GAUDANA et al., 2010).

O uso de colírios é a forma mais comum de tratar as doenças do segmento anterior do olho, mas sua efetividade terapêutica é limitada. A produção de lágrimas, o piscado, a absorção subconjuntival e a drenagem nasolacrimal são mecanismos dinâmicos eficientes para a eliminação de fármacos da superfície da córnea. As lágrimas constituem o principal obstáculo para a administração de fármacos no olho, porque fazem o lavagem da superfície do olho $(10 \mu \mathrm{L})$ a uma rapidez de $1 \mu \mathrm{L} \mathrm{min}{ }^{-1}$ que dissolve o fármaco reduzindo o tempo de contato entre 0 fármaco e a córnea com diminuição da sua biodisponibilidade (GAUDANA et al., 2010; Ll et al., 2015). Adicionalmente, a presença do colírio na superfície da córnea pode estimular a produção adicional de lágrimas incrementando a expulsão do 
fármaco para o exterior e sua drenagem através do ducto nasolacrimal (HAJARE et al., 2014).

O uso de colírios fortificados com antibióticos é mais efetivo e recomendado do que o uso de colírios comerciais nos casos onde se requer sua ação nas camadas internas da córnea (UNTERMAN et al., 1988; SILBIGER; STERN, 1992). Em casos de ceratite bacteriana, estes colírios são administrados cada 15 ou 30 min durante 48 a $72 \mathrm{~h}$. Esta é uma frequência de administração que geralmente requer hospitalização do paciente e gera controvérsia, devido à toxicidade e ao dano ao epitélio que as altas concentrações de antibiótico podem ocasionar (HYNDIUK et al., 1996; SCHAEFER et al., 2001).

Evidentemente os colírios não são sistemas ótimos de liberação de fármacos para a terapia ocular e novas estratégias são necessárias para incrementar a biodisponibilidade, aumentar o conforto do paciente e reduzir a incidência de efeitos secundários. Alternativas tais como as formulações de alta viscosidade, géis poliméricos, géis mucoadesivos, polímeros bioadesivos e insertos biodegradáveis e não biodegradáveis têm sido desenvolvidas para superar as deficiências dos colírios (BOURLAIS et al., 1998; GHATE; EDELHAUSER, 2006; KUNO; FUJII, 2011). Porém a maioria desses sistemas apresentam pelo menos uma das deficiências dos colírios e estes últimos continuam sendo a opção terapêutica de primeira mão (BENGANI et al., 2013).

Além dos colírios para o tratamento das ceratites também são usadas as injeções subconjuntivais, a administração sistêmica, a iontoforese, as lentes de contato e os escudos de colágeno (YANOFF; DUKER, 2014). As injeções conjuntivais geram dor e ansiedade no paciente, hemorragia subconjuntival e pouca uniformidade na distribuição do fármaco, sendo indicadas somente nos casos onde tem-se dificuldade na administração frequente do colírio por parte do paciente (O'BRIEN, 2003). Com a administração sistêmica se obtém baixas concentrações do fármaco na córnea, mas é útil quando há incidência de esclerite, endoftalmite ou risco de perfuração (MAGGS; MILLER; OFRI, 2008; YANOFF; DUKER, 2014). Por outro lado, a iontoforese é uma técnica não invasiva que emprega corrente elétrica para transportar fármacos carregados através da córnea, e portanto atingir concentrações efetivas desses fármacos com pouco desconforto para o paciente (CALLEGAN; O'CALLAGHAN; HILL, 1994; O'BRIEN, 2003). 
As lentes de contato, os escudos de colágeno e filmes poliméricos atuam como reservatórios que incrementam o tempo de contato entre o fármaco e a córnea, contribuindo assim a aumentar a biodisponibilidade do fármaco (BUSIN; SPITZNAS, 1988). O uso temporal destes dispositivos é indicado para o tratamento de úlceras oculares, pois reduz o trauma mecânico ocasionado pelo movimento das pálpebras facilitando a reparação do estroma e o epitélio (O'BRIEN, 2003; KHAN; KHAN, 2013). Contudo, estes dispositivos por si só são insuficientes para tratar as ceratites ulcerativas e precisam ser complementados com o uso de colírios de antibióticos.

Nos últimos anos, várias metodologias têm sido aplicadas na fabricação de lentes de contato para desenvolver dispositivos que liberem antibióticos de forma controlada, tais como a impressão molecular, a dispersão de vitamina $E$ e a incorporação de nanopartículas (BENGANI et al., 2013). Porém, o uso de lentes de contato para o tratamento de ceratites bacterianas gera controvérsia, devido ao risco de adesão microbiana na sua superfície, neovascularização da córnea e adesão destes dispositivos sob a superfície ocular (JACOBS; JOHNS; LE, 2013).

\subsection{Sistemas de liberação controlada de fármacos}

O desenvolvimento de sistemas de liberação controlada de fármacos está voltado à obtenção de uma melhor atividade farmacológica do fármaco com diminuição dos efeitos secundários. Nesse sentido, esses sistemas devem ser muito precisos na distribuição do fármaco e atuar especificamente no local da patologia (UCHEGBU; SCHATZLEIN, 2006).

Os sistemas de liberação controlada de fármacos têm sido amplamente estudados devido às limitações das formulações tradicionais. Estes sistemas são dispositivos externos ou internos planejados para facilitar a administração de fármacos ao paciente com o mínimo de desconforto. Os sistemas de liberação de fármacos podem ser localizados, com relativa liberdade, em diferentes zonas do organismo. Enquanto a maioria das formulações tradicionais devem ser injetadas ou ingeridas, os sistemas de liberação controlada podem ser administrados em um sítio específico, inseridos em uma cavidade, implantados ou aderidos externamente (SÁEZ; HERNÁEZ; LÓPEZ, 2003). Entre as vantagens mais destacadas destes sistemas estão: 
i) redução dos efeitos colaterais dos fármacos administrados, seja por aumento do seu tempo de liberação, levando a uma redução na sua dosagem, ou por liberação do fármaco nas células alvo;

ii) aumento na biodisponibilidade de peptídeos e proteínas com potencial terapêutico por proteção das mesmas contra a degradação ou inativação por parte do organismo;

iii) aumento da mobilização de fármacos hidrofóbicos em meio aquoso;

iv) redução do custo de tratamento devido à maior eficiência dos fármacos e menor número de administrações

v) redução da necessidade de auto-dosagem frequente do fármaco por parte do paciente, evitando assim, perda da efetividade terapêutica associada a erros de dosagem (YANG; PIERSTORFF, 2012).

\subsection{Polímeros para a liberação controlada de fármacos}

Os polímeros têm representado um papel muito importante no desenvolvimento de sistemas de liberação controlada de fármacos tanto hidrofóbicos como hidrofílicos (LIECHTY et al., 2010). Entre os polímeros mais usados para esse fim estão alguns polímeros quimicamente inertes como a poli(N-vinil-2-pirrolidona), o poli(álcool vinílico) (PVA), a poliacrilamida, o poli(etileno-co-acetato de vinila), polietilenoglicol e os polímeros derivados do ácido acrílico como o polimetilmetacrilato (PMMA). Em anos recentes o uso de polímeros biodegradáveis como o poli( ácido láctico) (PLA), o poli(ácido glicólico) (PGA), o ácido láctico-coácido glicólico (PLGA), os polianidridos e os poliortoesteres têm cobrado interesse para o desenvolvimento de sistemas de liberação sitio-alvo-específicos (SHAIK; KORSAPATI; PANATI, 2012). Polímeros naturais como o colágeno, a gelatina, a albumina, a dextrana, a quitosana, o amido, o ácido hialurônico e as ciclodextrinas também tem sido empregados como matrizes biodegradáveis de excelente biocompatibilidade, baixa toxicidade, e baixo custo para a liberação controlada de fármacos (JOSHI; PATEL, 2012; CHIFIRIUC et al., 2014).

Os materiais poliméricos liberam fármacos por meio de três mecanismos principais: difusão, reação química ou ativação com solvente. Na difusão o fármaco migra do interior do polímero até a superfície e depois é liberado no organismo. A liberação por reação pode dar-se por degradação do polímero ou por clivagem do 
fármaco ligado ao polímero. Já, a presença de um solvente pode ocasionar o intumescimento do polímero permitindo a mobilização e saída do fármaco, ou pode levar a formação de poros por osmose, através dos quais, ocorre a liberação continua do fármaco (LANGER, 1990; LIECHTY et al., 2010).

Existem três tipos de sistemas poliméricos de liberação de fármacos: sistemas conjugados polímero-fármaco, sistemas tipo reservatórios e sistemas matriciais (ou monolíticos). Em sistemas conjugados polímero-fármaco o fármaco é liberado na forma de um conjugado constituído pelo fármaco ligado covalentemente a um polímero hidrofílico biodegradável. O polímero é escolhido para melhorar a solubilidade do conjugado em meio aquoso, em relação ao fármaco livre (HOLOWKA; BHATIA, 2014). Nos sistemas tipo reservatório o fármaco é coberto por um filme polimérico e a velocidade de liberação do fármaco é determinada pelas propriedades do polímero (composição e massa molar), a espessura do filme e as propriedades físico-químicas do fármaco (solubilidade, massa molar e tamanho de partícula). O uso destes sistemas de liberação é útil quando o local de liberação é difícil de atingir pela administração sistêmica, como o olho ou o ouvido, ou o fármaco apresenta algum tipo de toxicidade e sua liberação precisa ser em longo prazo, como no caso de alguns agentes antitumorais (YANG; PIERSTORFF, 2012). Os sistemas matriciais ou monolíticos são similares aos sistemas tipo reservatório no sentido que o fármaco não se liga covalentemente ao polímero, mas no caso dos sistemas matriciais o fármaco fica disperso ou dissolvido na matriz polimérica e não encapsulado como no caso dos sistemas tipo reservatório.

O intumescimento de um sistema matricial pode ser interpretado como uma expansão volumétrica uniforme do sistema, que ocasiona a abertura de poros através da estrutura polimérica. Para que o fármaco possa se difundir através da matriz, o tamanho do poro deve ser suficientemente grande e exceder o tamanho da molécula hidrofilica ou da partícula hidrofóbica de fármaco (Figura 4B). Por outro lado, nos sistemas tipo reservatório o intumescimento ocorre através da expansão volumétrica não uniforme, regulada pela permeabilidade da cobertura polimérica. A saída do fármaco nos sistemas tipo reservatório depende do tamanho do poro gerado pelo intumescimento na matriz polimérica (Figura 4A) (HOLOWKA; BHATIA, 2014).

Figura 4 - Liberação de fármaco por intumescimento do sistema A - tipo reservatório e B - monolítico. 
A

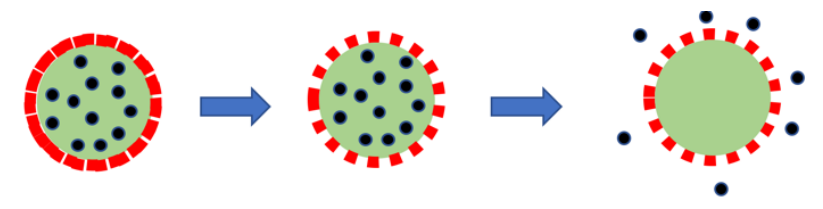

B

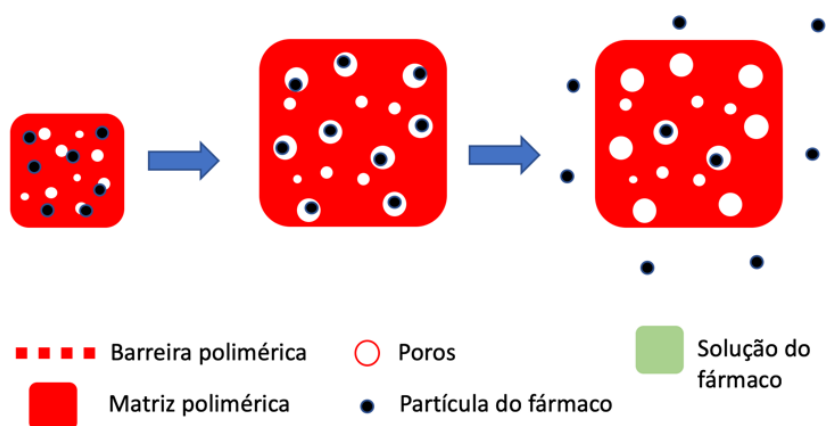

Fonte - adaptado de HOLOWKA; BHATIA, 2014.

O outro mecanismo envolvido na liberação de fármacos por sistemas matriciais e sistemas tipo reservatório é a degradação. A degradação do sistema dáse pela erosão do material em função do tempo em resposta às condições fisiológicas do meio. Em sistemas matriciais essa erosão pode ser superficial (surface erosion) com uma velocidade constante (Figura 5A) ou em massa (bulk erosion) com uma velocidade variável (Figura 5B) (BURKERSRODA; SCHEDL; GÖPFERICH, 2002).

Figura 5 - Liberação de fármaco por degradação A - superficial e B - em massa, de um sistema matricial.

A
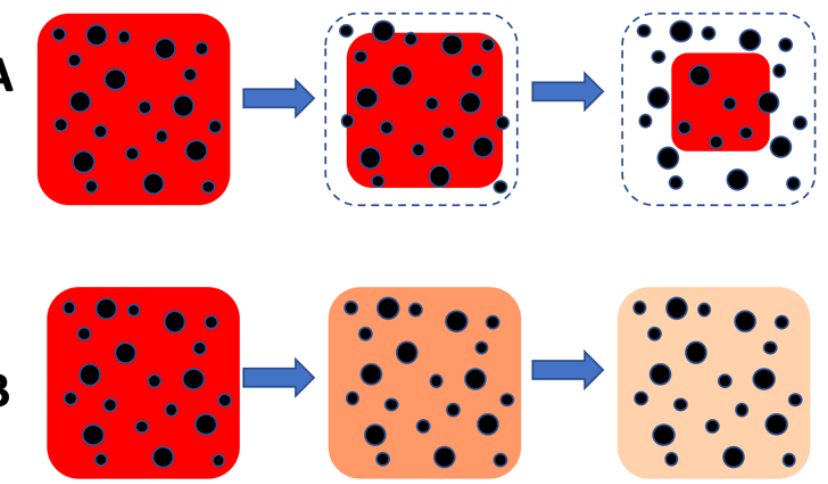

Matriz polimérica inicial

Partícula grande do fármaco

Matrizes

- Partícula pequena

Poliméricas

do fármaco

erosionadas

Fonte - Adaptado de HOLOWKA; BHATIA, 2014. 
A hidratação contínua dos sistemas poliméricos de liberação de fármacos ocasiona a degradação hidrolítica do polímero com a progressiva liberação do fármaco. Esta degradação depende da estabilidade das ligações das cadeias poliméricas nos fluidos fisiológicos (Figura 6) (VILAR; TULLA-PUCHE; ALBERICIO, 2012).

Figura 6 - Ligações em ordem crescente de labilidade com respeito à hidrólise em meio aquoso.

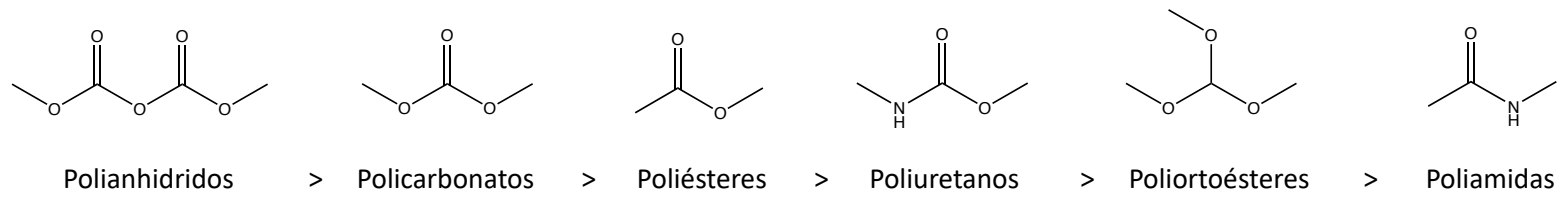

Fonte - VILAR; TULLA-PUCHE; ALBERICIO, 2012.

\subsection{Colágeno}

O colágeno é uma proteína fibrosa presente de forma abundante em tecidos animais como ossos, cartilagens, tendões, vasos sanguíneos, ligamentos, pele, córneas, discos intervertebrais e intestinos (CHAK; KUMAR; VISHT, 2013), representando aproximadamente o $25 \%$ do peso seco dos mamíferos (ALBERTS et al., 2002).

A estrutura molecular do colágeno consiste em uma hélice tripla de cadeias polipeptídicas, unidas entre si por ligações de hidrogênio entre resíduos de aminoácidos. A molécula de colágeno tem um comprimento, largura e massa de aproximadamente $3000 \AA, 15 \AA$ e 300 kDa respectivamente (KHAN; KHAN, 2013). A sequência de aminoácidos em cada cadeia polipeptídica contém basicamente 3 tipos de aminoácidos representados como glicina- $X-Y$, em que $X$ e $Y$ podem ser qualquer aminoácido, sendo prolina e 4-hidroxiprolina os mais comuns. Até o momento se conhecem 29 tipos de colágeno diferentes entre si pelas estruturas das suas hélices (CHATTOPADHYAY; RAINES, 2014).

Embora existam vários tipos de colágeno, somente alguns são usados para o desenvolvimento de biomateriais, sendo o colágeno tipo I o mais usado (YU et al., 2016). A estrutura helicoidal básica do colágeno tipo I é chamada de tropocolágeno (Figura 7A). A interação entre unidades de tropocolágeno dá lugar a uma estrutura altamente organizada, onde o empilhamento dos tropocolágenos cria um padrão repetitivo de bandas e gaps através das microfibrilas e fibrilas de 
colágeno (período D) (Figura 7B e 7C). No caso do colágeno nativo a distância entre gaps é aproximadamente $67 \mathrm{~nm}$ (STYLIANOU, 2017). Por sua vez, as fibrilas de colágeno se associam formando fibras e feixes de colágeno.

Figura 7 - Estrutura do colágeno tipo I. A - As cadeias polipeptídicas se organizam formando uma tripla hélice denominada tropocolágeno. $\mathbf{B}$ - As unidades de tropocolágeno se juntam formando uma microfibrila, caracterizada por um padrão repetitivo de bandas e gaps, que se denomina o período $D$ do colágeno. C - Usando um microscópio de força atômica, pode se observar o período $D$ na fibrila de colágeno tipo I.

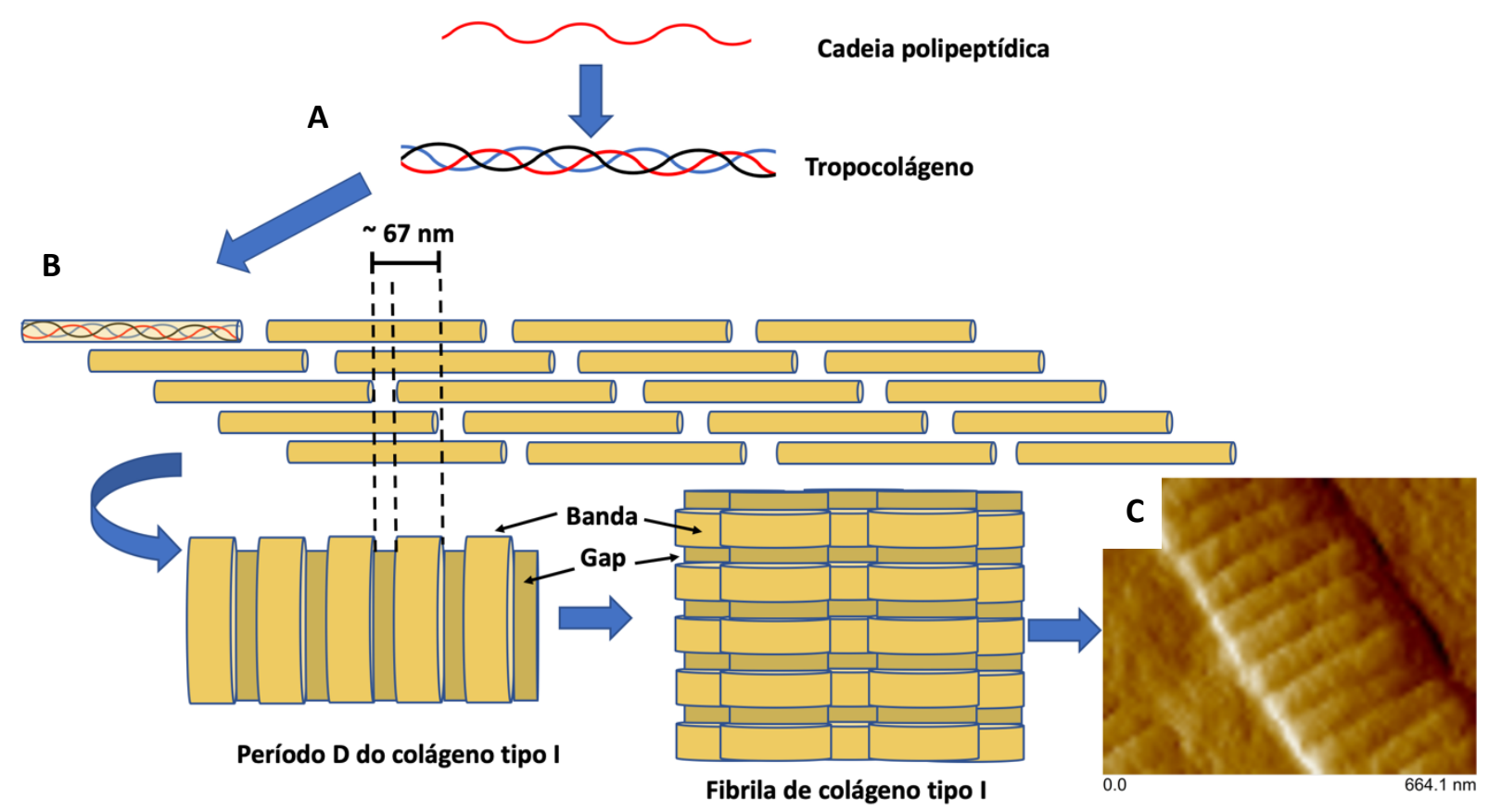
Fonte - Própria

As características que fazem do colágeno um biomaterial amplamente usado são: sua alta abundância, a facilidade de ser obtido a partir de organismos vivos, a sua hidrofilicidade, biodegradabilidade, biocompatibilidade, ausência de toxicidade e baixa antigenicidade. Adicionalmente, o colágeno tem capacidade para induzir e suportar o crescimento celular, atua como matriz para a liberação de fármacos, e as suas propriedades podem ser alteradas em resposta a modificações estruturais. Este polímero natural apresenta compatibilidade com uma variedade de polímeros sintéticos e pode ser moldado em diferentes formas como fios, filmes e esponjas. (LEE; SINGLA; LEE, 2001; CHAK; KUMAR; VISHT, 2013).

A baixa resistência mecânica do colágeno comumente limita seu uso como biomaterial (LEE; SINGLA; LEE, 2001). Uma das estratégias mais usada para 
melhorar as propriedades mecânicas do colágeno é a reticulação. As técnicas para a reticulação do colágeno dividem-se em físicas, químicas e enzimáticas. As técnicas físicas envolvem o uso de radiação ultravioleta ou calor para gerar ligações cruzadas. Nas técnicas químicas se empregam como agentes reticulantes diversos compostos, como por exemplo, carbodiimidas, diisocianato de hexametileno, genipina e aldeídos como o formaldeído e o glutaraldeído. Enzimas como a transglutaminase são usadas para reticular o colágeno. A diferença das técnicas químicas, menos subprodutos são gerados com a reticulacão enzimática do colágeno, eliminando o risco de induzir citotoxicidade (PARENTEAU-BAREIL; GAUVIN; BERTHOD, 2010).

Outras modificações químicas do colágeno como a esterificação, a acilação, a deaminação do grupo $\varepsilon$-amino da lisina, o bloqueio do grupo guanidina de resíduos de argininas e a hidrólise de grupos carboxiamina de resíduos de asparagina e glutamina (Figura 8 ) dão origem a matrizes de colágeno carregadas negativamente a pH 7,40, de alta biocompatibilidade, relativamente simples de obter e que são úteis para suportar o crescimento celular e a liberação de fármacos catiônicos (BET; GOISSIS; LACERDA, 2001).

Figura 8 - Representação esquemática da hidrólise dos agrupamentos carboxiamidas dos resíduos de asparagina e glutamina no colágeno.
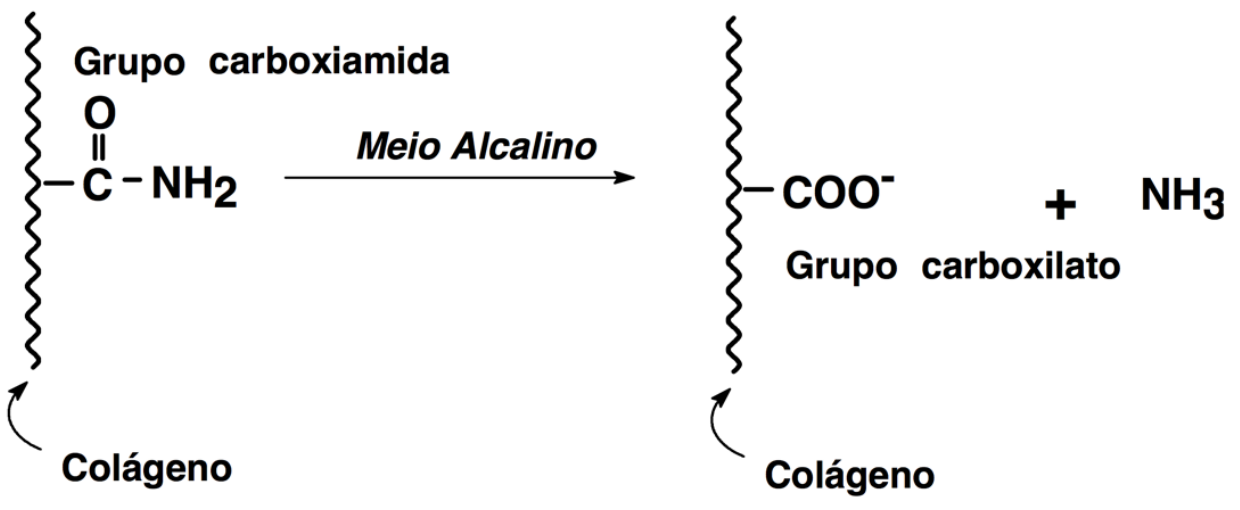

Fonte - RODRIGUES, 2011

O uso de colágeno como matriz para a liberação de fármacos tem recebido a atenção de muitos pesquisadores ao redor do mundo. As principais aplicações nas quais o colágeno é usado para a liberação de fármacos são os escudos de colágeno em oftalmologia, esponjas para queimaduras ou ferimentos, 
mini-pellets ou comprimidos para a liberação de proteínas, formulações de géis usando lipossomas para a liberação sustentada de fármacos, também como material para o controle da liberação transdérmica e para a fabricação de nanopartículas para a liberação de genes (LEE; SINGLA; LEE, 2001).

\subsubsection{Escudos de colágeno}

Os escudos de colágeno são geralmente feitos a partir de tecido escleral porcino ou tendão bovino (ROBIN et al., 1990). Estes dispositivos foram inicialmente desenvolvidos como curativos para a superfície ocular, devido à capacidade do colágeno de suportar o crescimento de células epiteliais em cultura (WILLOUGHBY; BATTERBURY; KAYE, 2002). Além disso, a biodegradabilidade e capacidade absortiva do colágeno faz dos escudos de colágeno dispositivos para a liberação controlada de diferentes tipos de fármacos, como antibióticos, inmunosupressivos, anti-inflamatórios e agentes anticoagulantes (SILBIGER; STERN, 1992).

O uso de escudos de colágeno previamente submergidos em soluções de antibióticos fomenta o processo de regeneração tecidual da córnea ao mesmo tempo que permite contrastar a infecção associada com a úlcera ocular, com pouco desconforto para o paciente. Estes dispositivos protegem a córnea do estresse mecânico das pálpebras e atuam como substratos para a ação de colagenases e MMPs evitando assim a destruição posterior do estroma e favorecendo a regeneração do epitélio, ao tempo que se reduz a incidência de inflamação e edema no estroma (WILLOUGHBY; BATTERBURY; KAYE, 2002).

Diversos trabalhos demostram que os escudos de colágeno são sistemas de liberação comparáveis ou superiores em efetividade, em relação aos colírios, as injeções intraoculares e as lentes de contato (ESHAR; WYRE; SCHOSTER, 2011). De forma similar às lentes de contato, os escudos de colágeno aumentam o tempo de contato entre o fármaco e a córnea. A não adesão microbiana sobre a superfície polimérica, a maior penetração do fármaco na córnea e a superior permeabilidade ao oxigênio constituem as vantagens dos escudos de colágeno sobre as lentes de contato. Pelo fato de serem feitos de colágeno, a degradação ocorre muito rapidamente (12 - $72 \mathrm{~h}$ dependendo do grau de reticulação do colágeno) pela ação proteolítica de enzimas presentes nas lagrimas. Assim, eles devem ser substituídos frequentemente por pessoal capacitado, o que eleva o custo do tratamento (SIMŞEK et al., 1996). Além disso, estes dispositivos não são totalmente transparentes 
reduzindo a visão do paciente, o que limitaria seu uso especialmente quando os dois olhos do paciente estão visualmente afetados (WILLOUGHBY; BATTERBURY; KAYE, 2002).

A degradação rápida dos escudos de colágeno também constitui uma desvantagem para o tratamento de infecções crônicas e o tratamento em animais hiperativos ou agressivos (ESHAR; WYRE; SCHOSTER, 2011). Além disso, os escudos de colágeno não são sistemas de liberação prolongada e liberam a maioria dos fármacos entre $30 \mathrm{~min}$ e $1 \mathrm{~h}$, sendo necessário o uso de colírios como adjuvantes (LI et al., 2015).

\subsection{Poli(álcool vinílico) (PVA)}

O PVA é um material amplamente usado em biomedicina como substituto de órgãos e tecidos, para a fabricação de lentes de contato, como veículo para a liberação de fármacos, na produção de scaffolds e como curativos para o tratamento de lesões e queimadoras da pele (PENG et al., 2012; ZHU et al., 2013).

Este polímero hidrofilico sintético (Figura 9) tem muitos sítios ativos para a formação de ligações de hidrogênio, estabilidade mecânica e química, transparência, flexibilidade, elasticidade, não é toxico nem carcinogênico, e tem pouca adesão celular (KANUNGO et al., 2013). Devido à alta hidrofilicidade do PVA, a adesão de proteínas na sua superfície não é favorecida e consequentemente o material tende a não aderir células e microrganismos, sendo classificado de bioinerte.

Figura 9 - Formula molecular do PVA.

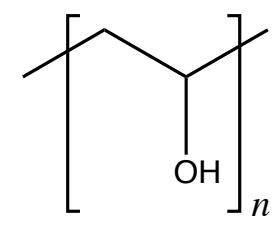

Devido à transparência, à permeabilidade ao oxigênio e nutrientes, e à natureza elástica dos filmes de PVA, estes materiais têm sido usado em oftalmologia para o desenvolvimento de lentes de contato, ceratopróteses (substitutos de córnea) (MIYASHITA et al., 2006), filmes e insertos oculares para a liberação de fármacos. Por exemplo, Balasubramaniam et al (2006) desenvolveram insertos oculares de PVA para a liberação de cloridrato de ciprofloxacina. Como a liberação total do 
antibiótico aconteceu em 24 h, os autores concluíram que estes insertos podem ser empregados como dispositivos de substituição diária, úteis para o tratamento de infecções oculares. O PVA também tem sido usado juntamente com polímeros naturais como a gelatina e a quitosana para o desenvolvimento de insertos oculares e lentes para a liberação de antibióticos (MUNDADA; SHRIKHANDE, 2006; LI et al., 2015). Porém, de modo similar aos escudos de colágeno, a efetividade destes sistemas depende do uso de colírios como adjuvantes.

\subsection{Blendas de PVA e colágeno}

As blendas e compósitos de PVA e colágeno têm as propriedades adequadas para o desenvolvimento de dispositivos biomédicos. Embora, a miscibilidade entre os dois polímeros só tem sido constatada para baixas concentrações de PVA ( 1\%) (SIONKOWSKA; SKOPIŃSKA; WISNIEWSKI, 2004), este polímero sintético é usado em maiores proporções para melhorar as propriedades mecânicas de dispositivos feitos com colágeno sem afetar sua biocompatibilidade (KANUNGO et al., 2013). Portanto, as blendas de PVA/colágeno apresentam certo grau de compatibilidade devido à hidrofilicidade de ambos polímeros e à boa capacidade para a formação de filmes (PENG et al., 2012). As propriedades mecânicas e a transparência do PVA, juntas com a afinidade celular do colágeno têm sido aproveitadas para o desenvolvimento de ceratopróteses com características fisiológicas e morfológicas similares às da córnea (MIYASHITA et al., 2006; WU et al., 2018).

Apesar das boas propriedades destas blendas, até o momento não existe relato na literatura em relação ao uso destes materiais como sistemas para a liberação de fármacos no olho. No presente estudo foram desenvolvidas blendas de PVA e colágeno aniônico na forma de membranas, para a liberação de antibióticos (ciprofloxacina, tobramicina e cloranfenicol) na superfície ocular e que superem as dificuldades associadas ao uso de lentes de contato e escudos de colágeno no tratamento das úlceras oculares em cães. A presença do PVA nas blendas conferiria transparência, bioestabilidade e resistência mecânica às membranas. Enquanto que, o colágeno serviria como substrato para a ação de proteinases, com o qual se reduziria a destruição do estroma e se favoreceria o processo de regeneração da córnea. Com a degradação do colágeno também se aumentaria progressivamente a 
permeabilidade ao oxigênio do material de forma similar a como acontece nos escudos de colágeno (WILLOUGHBY; BATTERBURY; KAYE, 2002).

Para o desenvolvimento das blendas foi selecionada uma proporção de PVA 3 vezes superior à do colágeno aniônico (em massa) para garantir uma transparência adequada e dispersão de fases (SIONKOWSKA; SKOPIŃSKA; WISNIEWSKI, 2004). Além disso, a maior proporção do PVA em relação ao colágeno pode ser adequada, porque uma vez degradado o colágeno, o PVA pode conservar a forma do dispositivo, protegendo o epitélio em regeneração contra o estresse mecânico ocasionado pelas pálpebras e reduziria a incidência de infeção secundária, o qual seria muito útil em estados crônicos da doença como o caso da úlcera ocular persistente. 


\section{MATERIAIS E MÉTODOS}

\subsection{Materiais}

O colágeno aniônico foi obtido a partir do tendão bovino. O PVA comercial de massa molar 70000-100000 e grau de hidrólise > 95\% foi adquirido da SigmaAldrich. Os antibióticos empregados foram o sulfato de tobramicina (Sigma-Aldrich) (solubilidade em água $=50 \mathrm{mg} \mathrm{mL}-1$ ), o cloridrato de ciprofloxacina (Bayer) (solubilidade em água $=30 \mathrm{mg} \mathrm{mL} \mathrm{mL}^{-1}$ ) e o cloranfenicol levógiro (Genix Ind. Farmacêutica Ltda.) (solubilidade em água $=3 \mathrm{mg} \mathrm{mL}^{-1}$ ).

\subsection{Obtenção do colágeno aniônico}

O colágeno aniônico foi obtido adotando a metodologia descrita por Lacerda, Plepis e Goissis (1998). O tendão bovino foi inicialmente limpo e desfiado. A massa resultante foi deixada em uma solução altamente alcalina $(\mathrm{pH} \sim 13)$ contendo sais de cloreto, sulfato e hidróxidos de cálcio, sódio e potássio durante períodos de tempo diferentes ( $24 \mathrm{~h}$ e $72 \mathrm{~h}$ ). O tratamento com essa solução ocasiona a hidrólise alcalina dos grupamentos carboxiamidas dos resíduos de asparagina e glutamina do colágeno. Após o respectivo tempo de tratamento a solução alcalina foi removida e substituída por uma segunda solução de cloretos e sulfatos de cálcio, sódio e potássio para a estabilização da hélice tripla do colágeno. Posteriormente a massa sólida foi tratada com ácido bórico 3\% (em massa/volume), seguido de lavagem com água deionizada e em seguida com uma solução de EDTA $\mathrm{pH}=11$ e finalmente com água deionizada até atingir um $\mathrm{pH}$ próximo a $7 . \mathrm{O}$ colágeno foi solubilizado em ácido acético $\mathrm{pH}=3,5 \mathrm{e}$, em seguida, armazenado em geladeira. As amostras de colágeno hidrolisado foram denominadas como COL24 e COL72 dependendo do tempo de tratamento alcalino. A concentração de colágeno em cada uma das amostras foi determinada por liofilização (em triplicata) em um equipamento da Edwards modelo Freeze Dryer Modulyo.

\subsection{Obtenção das membranas de PVA/colágeno aniônico}

As amostras de COL24 e COL72 foram ajustadas a uma concentração de $1 \%$ (em massa) de colágeno com ácido acético $(\mathrm{pH}=3,5)$ e misturadas independentemente com uma massa equivalente de PVA ( $3 \%$ em massa) em água 
deionizada. As misturas foram colocadas em moldes de Teflon ${ }^{\circledR}$ de $11 \times 1,5 \times 0,4 \mathrm{~cm}^{3}$ (7,0 g / membrana) e secas a temperatura ambiente sob fluxo de ar. As blendas obtidas em formato de membranas foram denominadas como PVA/C24 e PVA/C72.

\subsection{Obtenção de membranas de referência}

As amostras de COL24 e COL72 ajustadas ao 1\% (em massa) de colágeno (em ácido acético, $\mathrm{pH} \sim 3,5$ ), foram colocadas em moldes de Teflon ${ }^{\circledR} \mathrm{e}$ secas a temperatura ambiente sob fluxo de ar. O mesmo processo foi feito com o PVA (3\% em massa). As membranas obtidas foram denominadas como PVA, C24 e C72. Estas membranas foram usadas como materiais de referência para o estudo das propriedades dos sistemas de liberação controlada.

\subsection{Incorporação dos antibióticos}

Foram testadas 3 metodologias para a incorporação dos antibióticos:

\subsubsection{Por ligação covalente}

Aproximadamente $2 \mathrm{~g}$ das membranas PVA/C24 e PVA/C72 foram submergidas por $2 \mathrm{~h}$ em uma solução de glutaraldeído (GA) 1,0 mmol L-1 para reticular o colágeno. A reticulação das membranas com glutaraldeído consiste na formação de entrecruzamentos entre grupamentos $\varepsilon$-amino de lisinas e hidroxilisinas na estrutura primária do colágeno aniônico. A solução de GA foi ajustada a essa concentração, partindo do fato que cada grama de colágeno contém 390,91 $\mu \mathrm{mol}$ de grupos amino (GIGLIOTI, 2000). Depois desse tempo as membranas foram lavadas 3 vezes com tampão borato-glicina para parar a reação, e 3 vezes com água deionizada. As membranas foram secas a temperatura ambiente sob fluxo de ar.

A 1-etil-3-(3-dimetilaminopropil) carbodiimida (EDC) e a $\mathrm{N}$-hidroxisuccinimida (NHS) foram empregadas para a incorporação da tobramicina (Para os outros dois antibióticos de estudo, não foi utilizado este método) nas membranas previamente reticuladas com GA. A EDC ocasiona a ligação covalente entre os agrupamentos amino da tobramicina e os agrupamentos ácidos carboxila do colágeno numa reação catalisada pela NHS (LIU et al., 2014) (Apêndice 1). Aproximadamente $1 \mathrm{~g}$ das membranas reticuladas foi submergido em $100 \mathrm{~mL}$ de solução aquosa de EDC/NHS/Tobramicina (1\%/0,27\%/0,334\% em massa/volume) por $48 \mathrm{~h}$ em agitação constante, seguindo as proporções usadas por De Sousa 
(2001). Após $48 \mathrm{~h}$ as membranas foram retiradas da solução, lavadas rapidamente por três vezes com água deionizada e colocadas para secar sob fluxo de ar a temperatura ambiente. As membranas obtidas foram denominadas como PVA/C24/吕/Tb e PVA/C72/吕/Tb.

Esta metodologia, que somente foi aplicada para a incorporação de tobramicina, foi abandonada devido à rigidez das membranas obtidas e à baixa e rápida liberação do antibiótico (ver item 5.3).

\subsection{2. por absorção}

Para incorporar o fármaco por absorção, as membranas PVA/C24 e PVA/C72 foram submergidas durante 2, 4, 8 e $24 \mathrm{~h}$ em três diferentes soluções aquosas: Sulfato de tobramicina ( $\mathrm{Tb}$ ) $0,3 \%$ (em massa/volume), cloridrato de ciprofloxacina (Cpx) (em massa/volume) e cloranfenicol levogiro (Cfl) 0,3\% (em massa/volume). Após cada tempo, foram retiradas membranas da solução e secas a temperatura ambiente. A concentração das soluções de antibiótico usadas nesta metodologia é a mesma concentração comumente usada na formulação dos colírios comerciais, porém, com a vantagem de não conter excipientes que possam ser tóxicos.

Devido a esta metodologia ter sido mais eficiente para a incorporação de tobramicina com respeito aos outros antibióticos (ver item 5.2.2), foi usada exclusivamente para a incorporação deste fármaco e a membrana obtida foi denominada como PVA/C24/Tb.

\subsubsection{Por mistura no processo de obtenção das membranas}

A ciprofloxacina foi dissolvida na mistura polimérica durante o processo de obtenção das membranas PVA/C24 e PVA/C72 (descrita no item 4.3) numa concentração de 5\% (em massa seca). Esta concentração foi usada previamente por Ogawa e Plepis (2002) para liberação de ciprofloxacina a partir de compósitos de hidroxiapatita e colágeno aniônico. As misturas foram colocadas em moldes de Teflon $^{\circledR}$ (7,0 g para cada membrana) e secas a temperatura ambiente. O mesmo procedimento foi feito com o cloranfenicol. As membranas obtidas foram denominadas como PVA/C24/Cpx, PVA/C72/Cpx, PVA/C24/Cfl e PVA/C72/Cfl.

Com base nos resultados obtidos na liberação in vitro (item 5.3), foram obtidas membranas contendo tobramicina e ciprofloxacina simultaneamente, a uma 
concentração de $8 \%$ e $5 \%$ (em massa seca) respectivamente. Esta membrana foi denominada como PVA/C24/Cpx/Tb.

\subsection{Determinação do conteúdo de antibiótico incorporado nas} membranas

Fragmentos de 30-40 mg das membranas obtidas nos itens 4.5.1, 4.5.2 e 4.5.3 foram deixadas em $20 \mathrm{~mL}$ de ácido nítrico $0,5 \mathrm{~mol} \mathrm{~L}^{-1}$ a $70{ }^{\circ} \mathrm{C}$ até sua total dissolução. As soluções resultantes foram neutralizadas com NaOH $10 \%$ (em massa/volume) e filtradas. O volume de cada solução neutra foi ajustado a $100 \mathrm{~mL}$ em balão volumétrico. O conteúdo de ciprofloxacina e cloranfenicol nas soluções correspondentes foi determinado por espectrofotometria UV-vis a $271 \mathrm{~nm}$ e $278 \mathrm{~nm}$ respectivamente (Espectrofotômetro HITACHI U-3000). Para cada antibiótico foi feita uma curva analítica (em nitrato de sódio $0,5 \mathrm{~mol} \mathrm{~L}^{-1}$ ) para a interpretação das absorbâncias. As soluções contendo tobramicina foram derivatizadas com dinitrofluorbenzeno (DNFB) para que o conteúdo de antibiótico fosse determinado por espectrofotometria UV-vis a $415 \mathrm{~nm}$, seguindo a metodologia descrita por Ryan (1984).

\subsection{Liberação in vitro dos antibióticos}

As membranas obtidas nos items 4.5.1, 4.5.2 e 4.5.3 foram avaliadas quanto à sua capacidade de liberação in vitro de cada antibiótico. Três membranas de cada tipo foram colocadas independentemente (triplicata) em $20 \mathrm{~mL}$ de tampão fosfato salino $\mathrm{pH}=7,4$ (PBS) a $37^{\circ} \mathrm{C}$ com agitação constante, e foram retiradas amostras de $2 \mathrm{~mL}$ a tempos determinados $(0,5,1,2,4,8,24,48$ e 96 h). Cada volume retirado foi substituído pela mesma quantidade de PBS para manter o volume total constante. As concentrações de cada antibiótico nas amostras foram determinadas por espectrofotometria como foi descrito no item 4.6.

Os modelos de primeira ordem, de segunda ordem, de Hixson-Crowell, de Korsmeyer-Peppas e de Weibull (Anexo 1) foram usados para o ajuste dos dados obtidos na liberação de ciprofloxacina a partir das membrana de PVA/C24/Cpx (que foi o único sistema de liberação controlada in vitro obtido no item 5.3). A cinética de liberação foi determinada por comparação dos coeficientes de determinação $\left(R^{2}\right)$ de cada modelo matemático. 


\subsection{Caracterização}

\subsubsection{Espectroscopia no Infravermelho com transformada de Fourier (FTIR)}

Os espectros vibracionais na região do infravermelho das membranas foi usado um espectrofotômetro Shimadzu/IRAffinity 1 operando com transformada de Fourier e com acessório de refletância total atenuada horizontal com cristal de Seleneto de Zinco. Os espectros foram obtidos na faixa de 650 a $4000 \mathrm{~cm}^{-1}$ com resolução de $2 \mathrm{~cm}^{-1}$ e 32 varreduras.

\subsubsection{Calorimetria Exploratória Diferencial (DSC)}

As curvas DSC foram obtidas em um equipamento da TA Instruments, modelo DSC 2010 calibrado com padrão de índio. A razão de aquecimento foi de $10^{\circ} \mathrm{C} \mathrm{min}^{-1}$, na faixa de aquecimento de 5 a $120{ }^{\circ} \mathrm{C}$, em atmosfera de nitrogênio. Foram utilizadas massas de aproximadamente $20 \mathrm{mg}$, em suportes herméticos de alumínio.

\subsubsection{Termogravimetria}

As análises termogravimétricas (TGA) foram feitas com ajuda de um analisador térmico Mettler Toledo TGA/DSC 2. Massas de $2 \mathrm{mg}$ foram aquecidas em suportes de alumina na faixa de 30 a $900^{\circ} \mathrm{C}$ a uma razão de aquecimento de $10{ }^{\circ} \mathrm{C}$ $\mathrm{min}^{-1}$ em atmosfera de Nitrogênio $\left(50 \mathrm{~mL} \mathrm{~min} \mathrm{~m}^{-1}\right)$.

\subsubsection{Microscopia Eletrônica de Varredura (MEV)}

As micrografias das superfícies e a seções transversais das membranas foram obtidas em um microscópio eletrônico de varredura da marca Zeiss, modelo LEO-440 (Cambridge, England), com detector OXFORD (model 7060), operando com feixe de elétrons de $15 \mathrm{kV}$. As fraturas foram feitas por imersão das membranas em nitrogênio líquido. As amostras foram fixadas em suportes de alumínio com fita adesiva de carbono e recobertas com uma camada de ouro de $6 \mathrm{~mm}$ de espessura em um metalizador Coating System BAL-TEC MED 020 (BAL-TEC, Liechtensein). A pressão na câmara de metalização foi de $2 \times 10^{-2} \mathrm{mbar}$, a corrente de $60 \mathrm{~m} \AA$ e a taxa de deposição de $0,60 \mathrm{~nm} \mathrm{~s}^{-1}$. 


\subsubsection{Microscopia de Força Atômica (AFM)}

A topografia das superfícies das membranas foi observada usando um microscópio de força atômica (Dimension Icon Atomic Force Microscope with ScanAsyst, Bruker). As micrografias foram obtidas com o equipamento operado no modo "tapping" e em presença de ar. Superfícies de $25 \mu \mathrm{m}^{2}$ foram registradas a uma resolução fixa de $512 \times 512$ pixels. A frequência de varredura foi de $0,7 \mathrm{~Hz}$. A rugosidade das superfícies foi calculada a partir das micrografias usando o software NanoScope Analysis v1.40. Os parâmetros de rugosidade $\mathrm{R}_{\mathrm{a}}$ (rugosidade meia) e $\mathrm{R}_{\mathrm{q}}$ (Desvio meio quadrático ou RMS) são definidos pelas equações 1 e 2 , onde $n$ é o número de pontos amostrados dentro da superfície, $Z_{i}$ é o valor de altura do $i$-ésimo ponto e $Z_{\text {media }}$ é a média das alturas dos $n$ pontos.

$$
\begin{gathered}
R_{a}=\frac{1}{n} \sum_{i=1}^{n}\left|Z_{i}-Z_{\text {media }}\right| \\
R_{q}=R M S=\sqrt{\frac{1}{n} \sum_{i=1}^{n}\left(Z_{i}-Z_{\text {media }}\right)^{2}}
\end{gathered}
$$

\subsubsection{Intumescimento}

As membranas foram secas previamente em dessecador com $\mathrm{NaOH}$ (sólido) até atingir peso constante, após o que foram cortadas em segmentos retangulares de aproximadamente $20 \mathrm{mg}$. Cada segmento foi imerso em $5 \mathrm{~mL}$ de PBS a $25^{\circ} \mathrm{C}$. A tempos determinados (2, 5, 10, 20, 30, 40, 60, 90 e $\left.120 \mathrm{~min}\right)$ os segmentos foram retirados do PBS, tendo excesso de água removido com papel filtro e pesados. O grau de intumescimento e o conteúdo de água foram calculados usando as equações 3 e 4, onde $M_{\text {umida }}$ é a massa da membrana úmida e $M_{\text {seca }}$ é a massa da membrana seca.

$$
\begin{gathered}
\text { Grau de intumescimento }=\frac{M_{\text {úmida }}-M_{\text {seca }}}{M_{\text {seca }}} * 100 \\
\text { Conteudo de água }=\frac{M_{\text {úmida }}-M_{\text {seca }}}{M_{\text {úmida }}} * 100
\end{gathered}
$$




\subsection{7. Ângulo de contato}

A hidrofilicidade das membranas foi determinada a partir de medições de ângulo de contato usando um goniômetro CAM200 (KSV Instruments) pertencente ao Grupo de Polímeros "Prof. Bernhard Gross" IFSC/USP, a cargo do Prof. Dr. Osvaldo Novais de Oliveira Junior. Gotas de água de $10 \mu \mathrm{l}$ foram colocadas sobre a superfície de membranas de $10 \times 10 \mathrm{~mm}$ de dimensão usando uma microseringa de precisão. As medições de ângulo de contato foram feitas $10 \mathrm{~s}$ após aplicação da gota de água. Cada medida foi feita 10 vezes e a média foi relatada, como foi sugerido por Ibáñez-Redín et al, (2018). O ângulo de contato de ambos os lados da gota foi calculado com o software CAM 2008 usando o método de ajuste Young/Laplace (CARRIER; BONN, 2015).

\subsubsection{Permeabilidade ao vapor de água}

A permeabilidade ao vapor de água das membranas foi determinada de acordo com a norma ASTM E96-95 (1995). As membranas foram coladas nas aberturas circulares (área $=72,0 \pm 0,8 \mathrm{~mm}^{2}$ ) de frascos de vidro contendo $3 \mathrm{~mL}$ de água deionizada (umidade relativa de $100 \%$ ). Em seguida, os frascos foram pesados e guardados em dessecador contendo hidróxido de sódio (umidade relativa de $0 \%$ ) a $25{ }^{\circ} \mathrm{C}$. As massas dos frascos foram registradas 6 vezes durante um período de 24 h. Foram feitos gráficos de perda de massa $(m)$ em função do tempo ( $t$ ) e a constante angular $(\mathrm{m} / \mathrm{t})$ desses gráficos foi calculada por regressão linear. A taxa de permeabilidade ao vapor de água (TPV) foi calculada por meio da equação 5 , em que (A) é a área da abertura interna do frasco.

$$
\mathrm{TPV}=\frac{\mathrm{m}}{\mathrm{t}} \times \frac{1}{\mathrm{~A}}
$$

Finalmente, foi determinada a permeabilidade ao vapor de água (PV) usando a equação 6 , onde $\varepsilon$ é a espessura da membrana e $\Delta \mathrm{P}$ é a diferencia entre a de pressão parcial de vapor da água no frasco e a pressão parcial de vapor na atmosfera do dessecador (aproximadamente $3,168 \mathrm{kPa}$ a $25^{\circ} \mathrm{C}$ ).

$$
\mathrm{PV}=\frac{\mathrm{TPV} \times \varepsilon}{\Delta \mathrm{P}}
$$




\subsubsection{Propriedades mecânicas}

As propriedades mecânicas das membranas foram determinadas usando um texturômetro (Stable Micro System, modelo TAXT-PLUS, pertencente ao Lab. de Biomateriais e Nanotecnologia da Universidade de Sorocaba, UNISO, sob supervisão do Prof. Dr. Marco Vinícius Chaud. O equipamento foi previamente calibrado com uma célula de carga de $5 \mathrm{~kg}$. Para o ensaio de tração as presilhas (Mini Tensile Grips - Model A/MTG) foram acopladas ao equipamento. Um filme de dupla face foi colado nas faces interiores de ambas as presilhas (superior e inferior) para que o grip não danificasse a extremidade das amostras. As membranas foram recortadas na forma retangular para dimensões de $300 \mathrm{~mm}^{2}(30 \times 10 \mathrm{~mm}$ ) para um comprimento útil do corpo de prova de $10 \mathrm{~mm}$. A tração das membranas foi realizada conforme indicado na norma ASTM D882-02 (2002). A configuração do teste (TA Setting) foi ajustado para o modo de tensão (tension mode) e os parâmetros para as membranas foram: (i) $10 \mathrm{~mm}$ de extensão; (ii) velocidade de préteste $2,0 \mathrm{~mm} \mathrm{~s}^{-1}$, (iii) velocidade do teste $1,0 \mathrm{~mm} \mathrm{~s}^{-1}$, (iv) velocidade pós-teste $10 \mathrm{~mm} \mathrm{~s}^{-1}$, (v) força de gatilho $0,049 \mathrm{~N} \mathrm{e}$, (vi) distância máxima para deslocamento do grip superior foi de $25 \mathrm{~mm}$. Os dados obtidos no teste foram capturados pelo Texture Exponent Software ${ }^{\circledR}$ e apresentados na forma de figura e tabela. A espessura das membranas foi medida usando micrômetro manual (M110-25, Mitutoyo, Japão) com precisão de $0,01 \mathrm{~mm}$, O módulo de elasticidade foi determinado como a tangente das curvas de tensão-deformação dentro do limite elástico. A resistência na ruptura e a deformação na ruptura foram determinados a partir das equações 7 e 8 , onde $\sigma_{\text {ruptura }}$ é a resistência na ruptura, $F_{\text {ruptura }}$ é a força no momento da ruptura, A a área de secção transversal do corpo de prova, $D_{\text {ruptura }}$ é a deformação na ruptura, $\chi_{\text {ruptura }}$ é o incremento na longitude do corpo de prova no momento da ruptura e L é o comprimento útil do corpo de prova (neste caso igual à distância entre as presilhas).

$$
\begin{aligned}
\sigma_{\text {ruptura }} & =\frac{F_{\text {ruptura }}}{A} \\
D_{\text {ruptura }} & =\frac{\chi_{\text {ruptura }}}{L}
\end{aligned}
$$




\subsubsection{Transmissão de luz visível}

A porcentagem de transmissão de luz das membranas foi determinada com base na norma ASTM D1746-09 (2009), usando um Espectrofotômetro HITACHI U-3000 na faixa de 800 a 400 nm (luz branca) de comprimento de onda. As membranas cortadas em retângulos foram hidratadas em PBS antes e durante as medições sendo colocadas no interior das celas espectrofotométricas de quartzo (caminho ótico $=1 \mathrm{~cm})$.

\subsubsection{Solubilidade}

As medidas de perda de massa das membranas por solubilidade foram feitas seguindo a metodologia usada por Ghanbarzadeh, Almasi e Entezami (2010) com algumas adaptações. As membranas foram deixadas em dessecador com $\mathrm{NaOH}$ sólido (umidade relativa de $0 \%$ ) até atingir um peso constante. Depois, as membranas foram cortadas em segmentos retangulares de aproximadamente $20 \mathrm{mg}$, imersas em $20 \mathrm{~mL}$ de PBS a $37^{\circ} \mathrm{C}$, seladas e agitadas. Após $48 \mathrm{~h}$, as membranas foram retiradas do PBS e colocadas de novo no dessecador até atingir um peso constante. A solubilidade foi calculada usando a equação 9 , onde $M_{0}$ é a massa seca de membrana antes de ser imersa no PBS, $M_{t}$ é a massa seca da membrana após ser retirada do PBS.

$$
\text { Solubilidade }=\frac{\left(M_{0}-M_{t}\right)}{M_{0}} \times 100
$$

\subsubsection{Uniformidade e estabilidade de forma das membranas.}

As membranas foram cortadas em forma de discos de $0,5 \mathrm{~cm}^{2}$ usando um vazador metálico de $8 \mathrm{~mm}$, sendo este um formato plausível a ser usado durante o tratamento das úlceras oculares ${ }^{1}$. Posteriormente, usando um micrômetro manual (Mitutoyo, Japão, precisão de 0,01 mm) e um paquímetro (Mitutoyo, Japão, precisão de $0,05 \mathrm{~mm}$ ) foram medidos o diâmetro e a espessura de discos secos e de discos intumescidos (durante o tempo de liberação dos antibióticos em PBS).

\footnotetext{
1Informação fornecida pela Dra. Alessandra de Almeida Lucas (Departamento de Engenharia de Materiais - DEMa, UFSCar, São Carlos) e o Dr. Alexandre Lima de Andrade (Faculdade de Medicina Veterinária - FMVA, UNESP, campus de Araçatuba) via E-mail em 2016.
} 


\subsubsection{3. $\mathrm{pH}$ das membranas}

As membranas em formato de discos $\left(0,5 \mathrm{~cm}^{2}\right)$ foram deixadas em câmera fechada com vapor de $\mathrm{NH}_{4} \mathrm{OH}$ por $24 \mathrm{~h}$ com o intuito de reduzir a sua acidez. Posteriormente, cada disco foi submergido em $0,1 \mathrm{~mL}$ de água deionizada a $37^{\circ} \mathrm{C}$ durante $1 \mathrm{~h}$, sendo então o pH da água medido usando papel indicador.

\subsection{Atividade antimicrobiana (in vitro)}

Staphylococcus aureus ATCC 29213, Pseudomonas aeruginosa ATCC 27853 e Escherichia coli ATCC 25922 foram as linhagens bacterianas escolhidas como modelo para os estudos da atividade antimicrobiana dos sistemas de liberação. Estes testes foram feitos no laboratório de Epidemiologia e Microbiologia Molecular IFSC/USP sob supervisão da Profa. Dra. Ilana Lopes Baratella da Cunha Camargo.

\subsubsection{Concentração inibitória mínima (CIM) dos antibióticos}

A Concentração Inibitória Mínima (CIM) foi determinada de acordo com as recomendações do Clinical and Laboratory Standards Institute, CLSI (2017), pelo método de microdiluição em caldo. Uma solução estoque dos antibióticos foi preparada em água Mili-Q, diluída seriadamente em caldo Mueller Hinton Cátion Ajustado (MHCA) e distribuídas em placas de microdiluição de 96 poços. As bactérias foram incubadas $\left(5 \times 10^{5} \mathrm{CFU} / \mathrm{mL}\right)$ com o antibiótico por $24 \mathrm{~h}$, a $37^{\circ} \mathrm{C}$. No controle positivo foi adicionado bactéria sem o antibiótico para se observar o crescimento da mesma em caldo MHCA. No controle negativo, há apenas o meio de cultura MHCA, sem bactéria, para descartar a contaminação do mesmo. Após o período de incubação foi feita uma avaliação visual do crescimento microbiano.

\subsubsection{Experimento 1: Time-Kill}

O time-kill foi realizado em triplicata utilizando placas de 24 poços de $3 \mathrm{~mL}$. As membranas foram usadas em formato de discos $\left(0,5 \mathrm{~cm}^{2}\right)$. A ciprofloxacina foi inicialmente diluída em água à uma concentração de $5 \mu \mathrm{g} \mathrm{mL}^{-1}$ e posteriormente diluída em MHCA na CIM deste antibiótico. Os discos foram colocados nos poços, os quais tiveram 2,97 mL de MHCA adicionados (Figura 10). A bactéria foi cultivada por $18 \mathrm{~h}$ em tubo falcon de $15 \mathrm{~mL}$ contendo $10 \mathrm{~mL}$ de $\mathrm{BHI}$ (Brain-Heart Infusion). Após esse período, a amostra foi ajustada em solução fisiológica para 1,0 na escala 
McFarland, correspondente a $3 \times 10^{8}$ UFC $\mathrm{mL}^{-1}$ (unidades formadoras de colônias $/ \mathrm{mL}$ ). Em seguida, a amostra foi diluída em caldo MHCA para obtenção de $6 \times 10^{7}$ UFC $\mathrm{mL}^{-1}$. Alíquotas de $30 \mu \mathrm{L}$ da bactéria ajustada foram inoculados nos poços contendo as amostras, obtendo inóculos finais na concentração de $6 \times 10^{5}$ UFC $\mathrm{mL}^{-1}$.

Figura 10 - Distribuição das membranas nas placas de 24 poços para o time-kill. Tempos: membranas contendo antibiótico (PVA/C24/Cpx ou PVA/C24/Tb). C+ : controle positivo de crescimento (cultura bacteriana sem antibiótico). C- : controle negativo de crescimento (cultura bacteriana contendo antibiótico à CIM). C2+: segundo controle positivo de crescimento contendo membrana de PVA/C24.
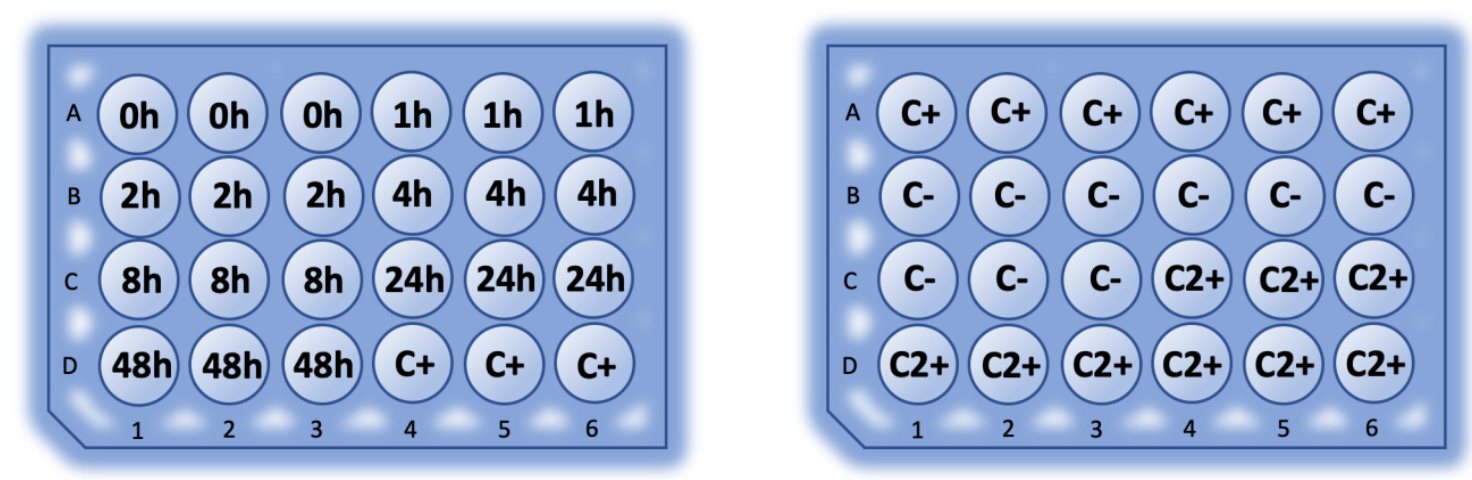

Fonte: Própria

As placas foram incubadas a $37^{\circ} \mathrm{C}$. Alíquotas de $20 \mu \mathrm{L}$ foram removidas dos poços a tempos determinados (1, 2, 4, 8, 24 e 48 h) e diluídas seriadamente em solução salina $\left(10^{-1}\right.$ a $\left.10^{-8}\right)$. 6 gotas de cada diluição foram plaqueadas pela técnica de microgotas $(15 \mu \mathrm{L})$ em placas de ágar BHI. As placas de BHI, que foram incubadas por $24 \mathrm{~h}$ a $37{ }^{\circ} \mathrm{C}$ para posterior contagem das UFC mL-1.

\subsubsection{Experimento 2}

Este experimento foi realizado em triplicata utilizando placas de 24 poços de $3 \mathrm{~mL}$. Cada membrana (em formato de disco de $0,5 \mathrm{~cm}^{2}$ ) foi colocada em PBS (1,13 mL para 3 membranas, conservando as proporções usadas no item 4.7 para a liberação in vitro) para liberação por 0, 1, 2, 4, 8, 24 e 48h. A bactéria foi ajustada conforme descrito no experimento de time-kill (item 4.21.2) e adicionada aos poços contendo MHCA. Em alguns poços foram adicionadas as membranas após a liberação e em outros nada foi adicionado para ter um controle positivo de crescimento (Figura 11). 
Figura 11 - Distribuição das membranas nas placas de 24 poços para o experimento 2. Tempos: membranas contendo antibiótico (PVA/C24/Cpx ou PVA/C24/Tb). C+ : controle positivo de crescimento (cultura bacteriana sem antibiótico).

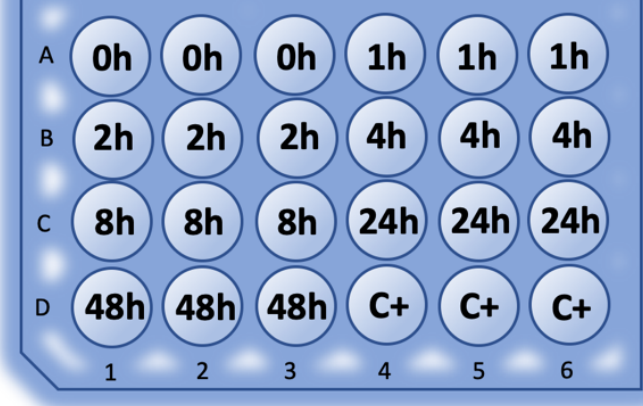

Fonte: Própria

As placas foram incubadas a $37^{\circ} \mathrm{C}$. Após $24 \mathrm{~h}$, foram retiradas alíquotas de $20 \mu \mathrm{L}$ e cada poço e diluídas seriadamente em solução salina $\left(10^{-1}\right.$ a $\left.10^{-8}\right)$. 6 gotas de cada diluição foram plaqueadas pela técnica de microgotas (15 $\mu \mathrm{L}$ ) em placas de ágar $\mathrm{BHI}$, que foram incubadas por $24 \mathrm{~h}$ a $37^{\circ} \mathrm{C}$ para posterior contagem das UFC $\mathrm{mL}^{-1}$.

\subsection{Estatística}

Cada dado foi relatado como a média \pm desvio padrão de 3 medições independentes. As diferenças entre os dados foram avaliadas empregando a análise de variância (ANOVA), sendo consideradas significativas para $p<0,05$. 


\section{RESULTADOS E DISCUSSÃO}

\subsection{Obtenção das membranas de PVA/colágeno aniônico}

As membranas de PVA/C24 e PVA/C72 apresentaram uma área de $26,45 \mathrm{~cm}^{2}$. Visualmente, as PVA/C24 secas foram levemente opacas comparadas com as PVA/C72, como era esperado devido à inibição na formação de fibrilas no colágeno hidrolisado por $72 \mathrm{~h}$ (ver Apêndice 2), como resultado do maior numero de agrupamentos carboxila na sua estrutura primaria, quando comparado ao colágeno hidrolisado por 24 h (BET; GOISSIS; LACERDA, 2001). Porém, quando hidratadas, as duas membranas foram visualmente transparentes e flexíveis, características adequadas para obter, a partir delas, dispositivos para a reparação da córnea.

O proposito de ter usado duas amostras de colágeno com tempos de hidrólise diferentes na preparação das membranas foi constatar se existe relação entre o numero de cargas negativas no colágeno e a incorporação ou liberação dos antibióticos.

\subsection{Incorporação dos antibióticos}

\subsubsection{Por ligação covalente}

A primeira metodologia testada para a incorporação dos antibióticos foi a ligação covalente de tobramicina ao colágeno aniônico, usando o EDC e a NHS. As membranas foram previamente reticuladas com glutaraldeído para reduzir o número de grupamentos amino no colágeno e consequentemente favorecer o maior número de ligações entre agrupamentos carboxila do colágeno à tobramicina, como foi descrito por De Sousa (2001).

Com esta metodologia foram obtidas membranas com aparência retorcida, devido, provavelmente ao um aumento na rigidez das mesmas como consequência da reticulacão do colágeno (ver Apêndice 2). Além disso, houve uma perda notável na transparência destas membranas comparadas com as membranas $\mathrm{PVA} / \mathrm{C} 24$ e PVA/C72. A quantidade de tobramicina incorporada em cada membrana usando esta metodologia é mostrada na Tabela 1. 
Tabela 1 - Eficiência na incorporação de tobramicina por ligação covalente

\begin{tabular}{ccc}
\hline Membrana & Tobramicina incorporada $\left(\boldsymbol{\mu g} / \mathbf{c m}^{2}\right)$ & $\%$ de Tobramicina Incorporada* \\
\hline PVA/C24/GA/Tb & $484 \pm 18$ & $12,2 \pm 1,0^{* *}$ \\
PVA/C72/GA/Tb & $444 \pm 12$ & $10,6 \pm 1,3^{* *}$ \\
\hline
\end{tabular}

* \% calculada com respeito à massa seca das membranas.

** Sem diferença significativa $(p>0,05)$

Devido a que as quantidades de tobramicina nas duas membranas não diferem significativamente entre se $(p>0,05)$, se infere que, ao contrario do esperado a diferença no numero de cargas negativas entre o COL72 e o COL24 não influiu na eficiência de incorporação de tobramicina por ligação covalente.

\subsubsection{Por absorção}

Não houve mudanças físicas perceptíveis nas membranas PVA/C24 e PVA/C72 após serem submergidas nas soluções de tobramicina e cloranfenicol (ver Apêndice 2). Mas no caso das membranas submergidas em solução de ciprofloxacina as membranas apresentaram uma leve coloração amarela. A eficiência na incorporação dos antibióticos foi independente do tempo de imersão das membranas nas soluções dos antibióticos $(p>0,05)$ e significativamente superior para tobramicina em relação aos outros dois antibióticos (Tabela 2 e 3). Portanto, a metodologia de absorção foi adotada unicamente para a tobramicina, com um tempo de imersão de somente $2 \mathrm{~h}$, obtendo-se uma membrana denominada PVA/C24/Tb contendo $313 \pm 9 \mu \mathrm{cm}^{-2}$ de tobramicina e outra membrana denominada PVA/C72/Tb contendo $296 \pm 5 \mu \mathrm{g} \mathrm{cm}^{-2}$ de tobramicina.

Tabela 2 - Eficiência na incorporação da tobramicina, a ciprofloxacina e o cloranfenicol por absorção nas membranas de PVA/C24. A diferença entre as porcentagens de incorporação de cada antibiótico para os diferentes tempos de imersão não foi estatisticamente significativa $(p>0,05)$

\begin{tabular}{cccc}
\hline \multirow{2}{*}{$\begin{array}{c}\text { Tempo de } \\
\text { imersão }(\mathbf{h})\end{array}$} & \multicolumn{3}{c}{ \% de antibiótico absorvido* } \\
\cline { 2 - 4 } & Tobramicina & Ciprofloxacina & Cloranfenicol \\
\hline 2 & $8,0 \pm 0,3$ & $1,8 \pm 0,1$ & $1,7 \pm 0,1$ \\
4 & $8,1 \pm 0,3$ & $2,1 \pm 0,4$ & $1,9 \pm 0,2$ \\
8 & $8,3 \pm 0,3$ & $1,8 \pm 0,1$ & $1,8 \pm 0,1$ \\
24 & $7,9 \pm 0,2$ & $1,9 \pm 0,3$ & $2,2 \pm 0,2$ \\
\hline
\end{tabular}

* \% calculada com respeito à massa seca das membranas. 
Tabela 3 - Eficiência na incorporação da tobramicina, a ciprofloxacina e o cloranfenicol por absorção nas membranas de PVA/C72. A diferença entre as porcentagens de incorporação de cada antibiótico para os diferentes tempos de imersão não foi estatisticamente significativa $(p>0,05)$

\begin{tabular}{cccc}
\hline \multirow{2}{*}{$\begin{array}{c}\text { Tempo de } \\
\text { imersão (h) }\end{array}$} & \multicolumn{3}{c}{ \% de antibiótico absorvido* } \\
\cline { 2 - 4 } & Tobramicina & Ciprofloxacina & Cloranfenicol \\
\hline 2 & $7,6 \pm 0,5$ & $1,8 \pm 0,1$ & $1,3 \pm 0,1$ \\
4 & $7,6 \pm 0,2$ & $2,3 \pm 0,4$ & $1,2 \pm 0,3$ \\
8 & $8,1 \pm 0,4$ & $1,7 \pm 0,3$ & $1,2 \pm 0,2$ \\
24 & $7,7 \pm 0,3$ & $1,9 \pm 0,2$ & $1,3 \pm 0,3$ \\
\hline
\end{tabular}

* \% calculada com respeito à massa seca das membranas.

A quantidade de antibiótico absorvido na matriz polimérica depende de vários fatores como o conteúdo de água e a espessura do material, a massa molar do antibiótico e a solubilidade do antibiótico na matriz polimérica (GUZMANARANGUEZ; COLLIGRIS; PINTOR, 2013). Provavelmente este último fator foi o que mais contribuiu na eficiência de absorção dos antibióticos nas membranas. Isso porque, a tobramicina tem a maior solubilidade em água (ver item 4.1) entre os antibióticos usados; portanto é o antibiótico mais hidrofílico e pode ser dissolvido com maior facilidade pela matriz hidrofílica formada por colágeno e PVA, o que explicaria a maior eficiência na absorção deste antibiótico comparado com a eficiência de absorção dos outros dois antibióticos.

Um outro fator que pode ter facilitado a absorção de tobramicina em relação aos outros antibióticos é o maior numero de grupamentos hidroxila e amino na sua estrutura molecular (Figura 3 ), os quais interagiriam com matriz polimérica através de ligações de hidrogênio com os grupamentos hidroxila do PVA.

De forma semelhante ao processo de incorporação de tobramicina por ligação covalente, na incorporação de tobramicina por absorção não foi observada uma diferencia significativa $(p>0.05)$ entre as quantidades incorporadas nas membranas de PVA/C24/Tb e PVA/C72/Tb indicando que a quantidade de cargas negativas do colágeno aniônico não influiu na retenção deste antibiótico na matriz polimérica.

\subsubsection{Por mistura no processo de obtenção das membranas}

Esta metodologia foi usada especificamente para a incorporação de ciprofloxacina e cloranfenicol, uma vez que a tobramicina foi incorporada usando as 
duas anteriores metodologias. Nesta metodologia uma quantidade fixa de antibiótico foi adicionada no momento da mistura do PVA e o Colágeno aniônico.

As membranas obtidas não apresentaram diferença física perceptível com relação às membranas de PVA/C24 e PVA/C72, exceto no caso da ciprofloxacina onde se observou uma leve coloração amarela das membranas (ver Apêndice 2), similar ao que ocorreu na incorporação de ciprofloxacina por absorção (item 5.2.2). A quantidade de ciprofloxacina e cloranfenicol incorporados nas membranas usado está metodologia é mostrada na Tabela 4.

Tabela 4 - Eficiência na incorporação de ciprofloxacina e cloranfenicol por mistura durante a obtenção das membranas

\begin{tabular}{ccc}
\hline Membrana & Antibiótico incorporado $\left(\boldsymbol{\mu g} \mathbf{~ c m}^{-2}\right)$ & \% de antibiótico incorporada* \\
\hline PVA/C24/Cpx & $287 \pm 2$ & $4,7 \pm 0,1$ \\
PVA/C72/Cpx & $296 \pm 1$ & $4,5 \pm 0,1$ \\
PVA/C24/Clf & $289 \pm 4$ & $4,7 \pm 0,1$ \\
PVA/C72/Clf & $306 \pm 1$ & $5,1 \pm 0,2$ \\
\hline
\end{tabular}

* \% calculada com respeito à massa seca das membranas.

Usando esta metodologia foram obtidas membranas de PVA/C24/Cpx/Tb com uma concentração de ciprofloxacina e tobramicina de $304 \mathrm{mg} \pm 1 \mathrm{mg}(4,6 \% \pm$ $0,2 \%)$ e $684 \mathrm{mg} \pm 3 \mathrm{mg}(10,4 \% \pm 0,5 \%)$ respectivamente. Estas membranas foram feitas após testar a liberação in vitro das outras membranas (ver item 5.3) com o proposito de testar a liberação simultânea dos dois antibióticos.

\subsection{Liberação in vitro dos antibióticos}

As membranas de PVA e colágeno aniônico foram avaliadas em relação à liberação in vitro de cada um dos antibióticos, com o intuito de selecionar os sistemas de liberação mais adequados para o tratamento da infecção associada às úlceras oculares em cães.

Apesar da incorporação de tobramicina ter sido relativamente alta, usando a metodologia de ligação covalente, em relação às outras duas metodologias (Tabela 1), menos de $10 \%$ dessa tobramicina foi liberada em $1 \mathrm{~h}$ pelas membranas

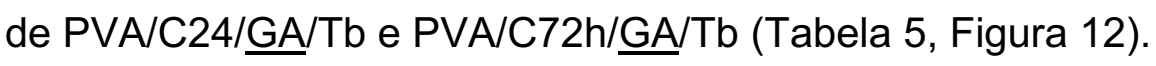


Tabela 5 - Porcentagem de antibiótico liberado pelas membranas depois de $96 \mathrm{~h}$ em PBS

\begin{tabular}{cc}
\hline Membrana & $\begin{array}{c}\text { Porcentagem de antibiótico } \\
\text { liberado }\end{array}$ \\
\hline PVA/C24/GA/Tb & $7 \pm 1$ \\
PVA/C72/GA/Tb & $5 \pm 1$ \\
PVA/C24/Tb & $37 \pm 6$ \\
PVA/C72/Tb & $57 \pm 9$ \\
PVA/C24/Cpx & $96 \pm 5$ \\
PVA/C72/Cpx & $103 \pm 1$ \\
PVA/C24/Clf & $100 \pm 1$ \\
PVA/C72/Clf & $94 \pm 4$ \\
PVA/C24/Cpx/Tb & $97 \pm 4 / 64 \pm 1^{*}$
\end{tabular}

${ }^{*}$ Quantidade liberada de Ciprofloxacina / Tobramicina

Figura 12 - Curvas de liberação de tobramicina para as membranas de PVA/C24/GA/Tb (-) e PVA/C72/GA/Tb (一) obtidas usando a metodologia de ligação covalente.

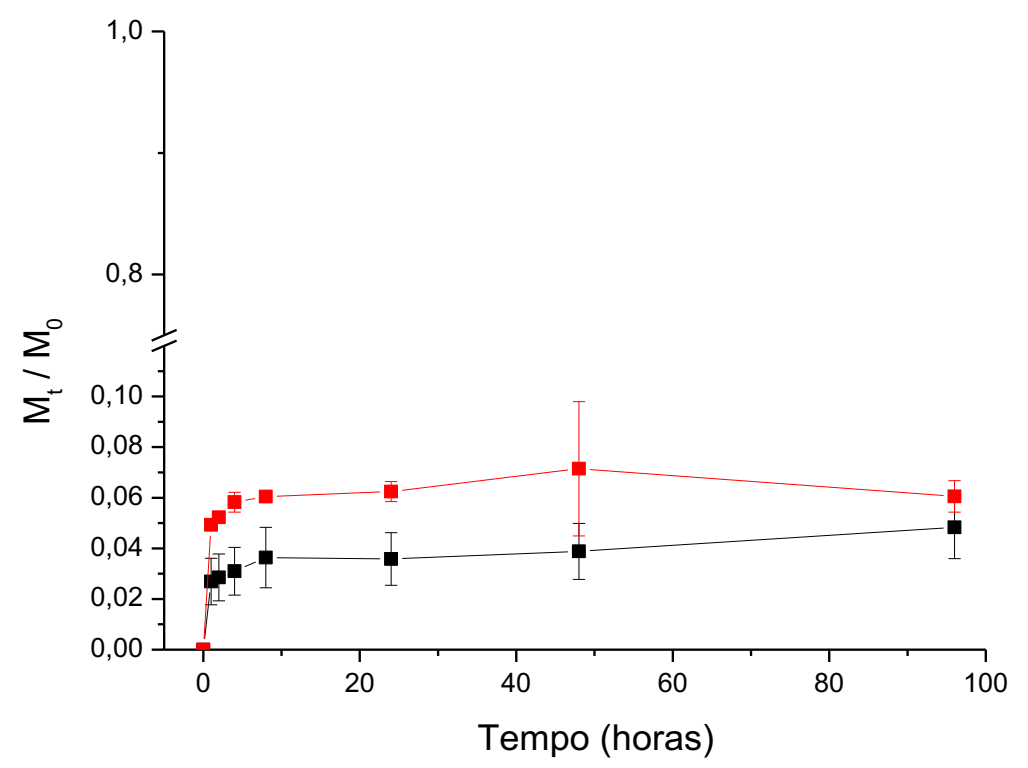

Esta liberação baixa e rápida de tobramicina deixa em dúvida o potencial destas membranas para inibir o crescimento microbiano. Além disso, como já foi mencionado, estas membranas tiveram uma aparência retorcida, causada provavelmente por um aumento na rigidez do material (devido à reticulacão, tanto com o glutaraldeído como com o EDC). Este fato dificultaria a aplicação destas membranas na superfície ocular e provavelmente geraria desconforto para o 
paciente. Por estes motivos, esta metodologia foi substituída pela metodologia de absorção do antibiótico que, além de ser mais simples promove uma liberação de tobramicina mais eficiente (Tabela 5) com membranas mais flexíveis e translúcidas. Por outro lado, foi observada uma alta eficiência na liberação de ciprofloxacina e cloranfenicol incorporados por mistura durante processo de obtenção das membranas (Tabela 5).

Os perfis de liberação de tobramicina e ciprofloxacina são apresentados Figuras 13 e 14. A liberação de ciprofloxacina por parte das membranas de PVA/C24/Cpx estendeu-se por um período de $48 \mathrm{~h}$ aproximadamente, enquanto que nas membranas de PVA/C72/Cpx a retenção do antibiótico foi menor e a liberação mais rápida (100\% antes de $1 \mathrm{~h}$ ). No caso das membranas de PVA/C24/Tb e PVA/C72/Tb uma significativa quantidade de tobramicina foi retida no material durante todo o período de liberação. Em contraste, a liberação do cloranfenicol por parte das membranas de PVA/C24/Cfl e PVA/C72/Cfl foi muito rápida (100\% antes de $1 \mathrm{~h}$ ), não havendo praticamente nenhuma diferença entre elas.

Figura 13 - Curvas de liberação de tobramicina (-), ciprofloxacina (-) e cloranfenicol (—) para as membranas de PVA/C24/Tb (obtida por absorção de tobramicina), PVA/C24/Cpx e PVA/C24/Cfl (obtidas por mistura dos antibióticos no processo de obtenção das membranas), respectivamente.

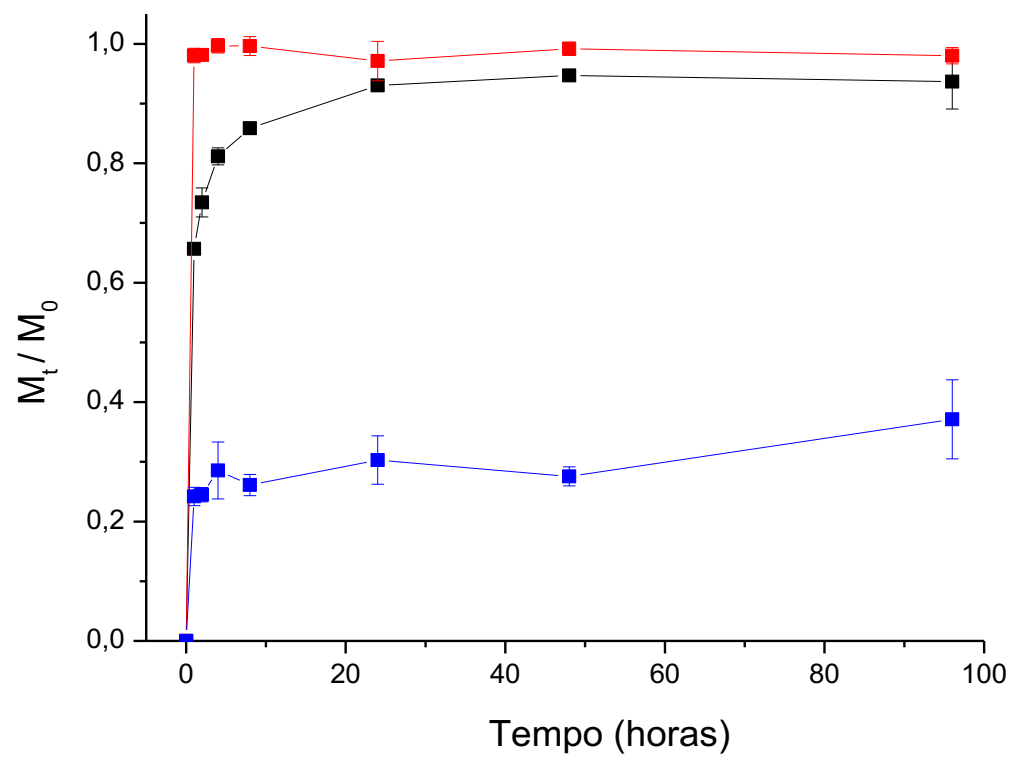


Figura 14 - Curvas de liberação de tobramicina (-), ciprofloxacina (-) e cloranfenicol (-) para as membranas de PVA/C72/Tb (obtida por absorção de tobramicina), PVA/C72/Cpx e PVA/C72/Cfl (obtidas por mistura dos antibióticos no processo de obtenção das membranas), respectivamente.

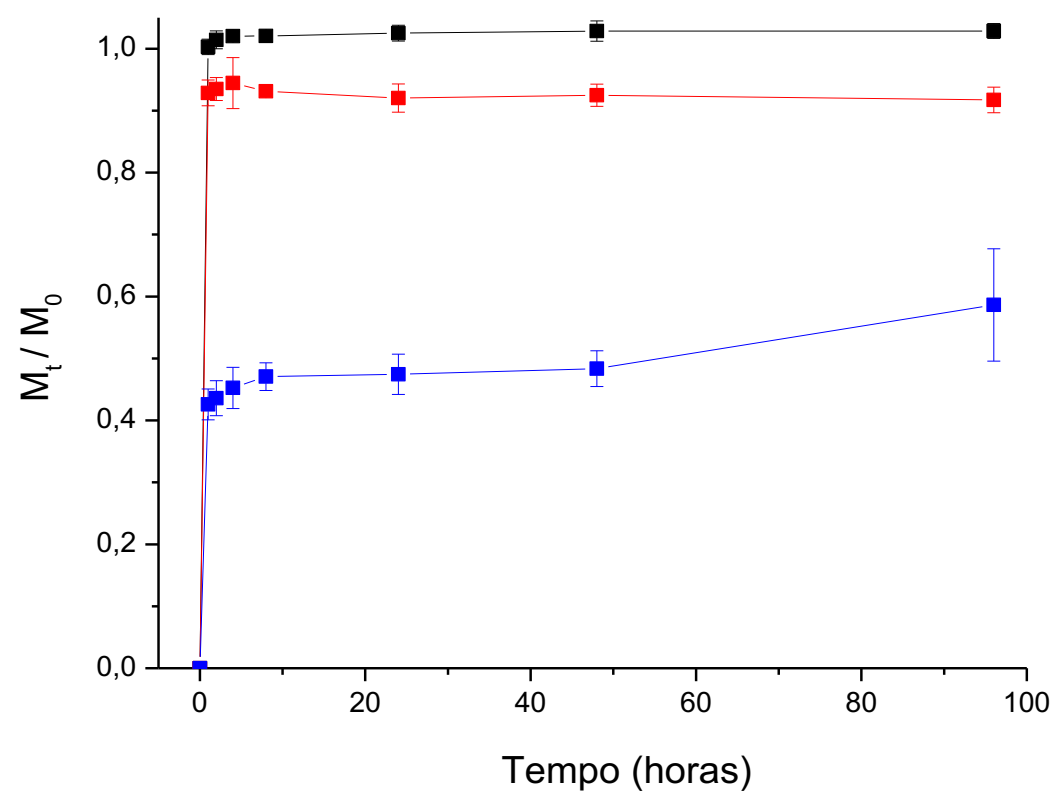

Evidentemente, as diferenças nos perfis de liberação de tobramicina e a ciprofloxacina são associadas aos diferentes tempos de hidrólise do colágeno aniônico. A tobramicina e a ciprofloxacina são antibióticos de caráter catiônico em meio ácido e neutro (SRIPRIYA; KUMAR; SEHGAL, 2004), que podem interagir eletrostaticamente com a matriz aniônica do colágeno. Nesse sentido, poderia-se supor, que entre maior a carga aniônica do colágeno a retenção da tobramicina e ciprofloxacina durante a liberação deveria ser maior. Mas o observado foi o contrário, as membranas de PVA/C24/Tb e PVA/C24/Cpx retiveram maior quantidade do antibiótico do que as membranas de PVA/C72/Tb e PVA/C72/Cpx.

$O$ intumescimento do material pode ser a causa desse comportamento no perfil de liberação das membranas. O grau de intumescimento do colágeno aniônico aumenta proporcionalmente com o tempo de hidrólise alcalina como mostrado por RODRIGUES, et al (2011). Nesse sentido, o intumescimento maior das membranas contendo colágeno hidrolisado por $72 \mathrm{~h}$ permitiria uma difusão maior do fármaco através da matriz polimérica e, consequentemente uma maior liberação com relação às membranas contendo colágeno hidrolisado por $24 \mathrm{~h}$.

Entre as membranas estudadas, a membrana de PVA/C24/Cpx foi a única com um comportamento de liberação controlada do antibiótico durante 48 h. Com a alta liberação inicial (ou burst) observada para este sistema se garantiria que a 
córnea infectada receberia concentrações de antibiótico suficientes para inibir o crescimento microbiano (ver item 5.6.12.1) desde o começo do tratamento, ao mesmo tempo que se reduziria também a incidência de resistência microbiana (DASH; CUDWORTH, 1998). Também é fundamental destacar que o tempo de liberação das membranas de PVA/C24/Cpx foi superior ao relatado em outros estudos referentes a sistemas similares. Por exemplo, os insertos oculares de PVA desenvolvidos por Balasubramaniam et al. (2006) liberaram a totalidade da ciprofloxacina em um período de $24 \mathrm{~h}$. O mesmo tempo de liberação in vitro de $24 \mathrm{~h}$, foi relatado por Jain et al, (2011) usando membranas de PVA e gelatina como insertos oculares para a liberação de ciprofloxacina.

As membranas de PVA/C24/Tb e PVA/C72/Tb também são sistemas interessantes de serem estudados, embora não tenha sido comprovada sua liberação controlada in vitro. Certamente o método usado para testar a liberação não consegue simular todas as condições presentes na córnea, como por exemplo, a presença de enzimas proteolíticas. Assim como a tobramicina retida nestes materiais, provavelmente pode ser liberada na medida que o colágeno for biodegradado pela ação de proteases presentes no fluido lacrimal ou produzidas por microrganismos patógenos como $P$. aeruginosa. Para verificar esta suposição, a liberação de tobramicina a partir destas membranas deve ser estudada através de testes antimicrobianos in vitro e testes in vivo.

Por último foram feitas membranas de PVA/C24/Cpx/Tb para a liberação simultânea dos dois antibióticos. O esperado destas membranas era uma liberação controlada de ciprofloxacina acompanhada de uma liberação mais lenta e estendida de tobramicina, similar ao observado previamente com as membranas de $\mathrm{PVA} / \mathrm{C} 24 / \mathrm{Cpx}$ e PVA/C24/Tb. Porém, a rápida liberação de ciprofloxacina (Figura 15) fez destas membranas sistemas pouco úteis para os objetivos deste estudo, e portanto, foram descartadas. 
Figura 15 - Curva de liberação de tobramicina (-), ciprofloxacina (-) para as membranas de $\mathrm{PVA} / \mathrm{C} 24 / \mathrm{Cpx} / \mathrm{Tb}$. Estes antibióticos foram incorporados por mistura no processo de obtenção das membranas.

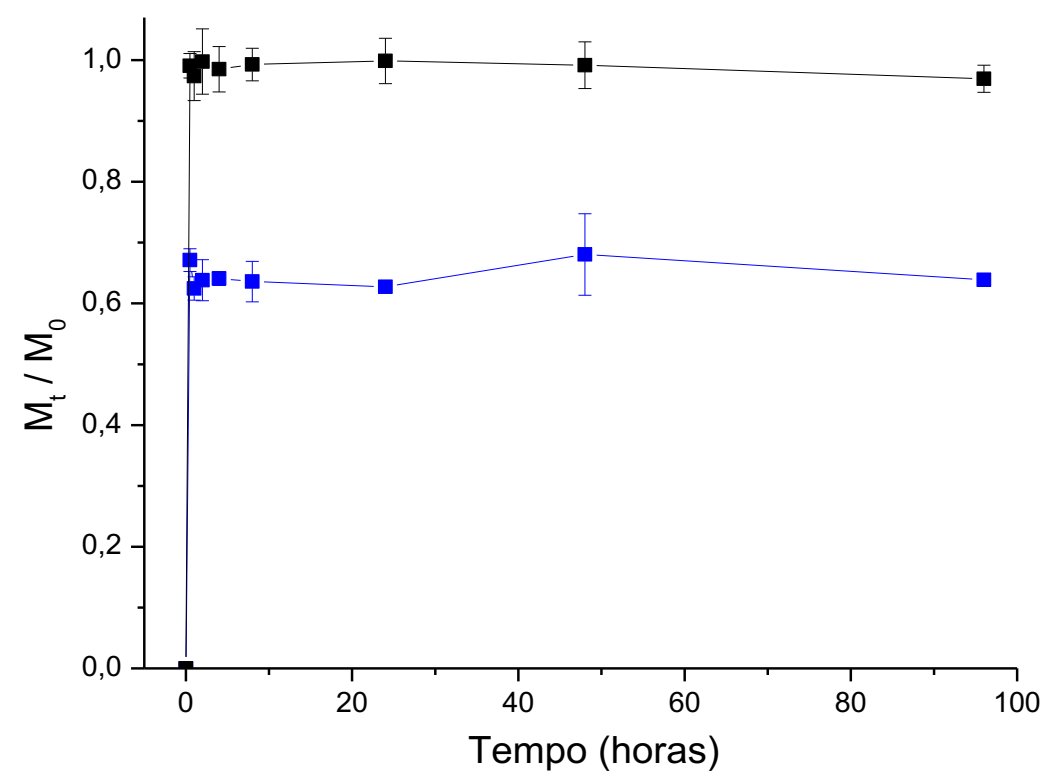

Em base nas observações anteriores as membranas de PVA/C24/Cpx foram selecionados como os sistemas mais adequados para a liberação controlada de ciprofloxacina in vitro. As membranas de PVA/C24/Tb também foram escolhidas para os posteriores estudos em virtude da quantidade de tobramicina retida por estas (superior às membranas de PVA/C72/Tb) e seu potencial para liberá-la por degradação enzimática do material. As membranas de PVA/C24/Cfl e PVA/C72/Cfl foram descartadas devido à rápida liberação do antibiótico.

\subsection{Cinética de liberação}

Os dados de liberação in vitro das membranas de PVA/C24/Cpx (item 5.3) foram tratados com modelos cinéticos com o intuito de determinar a cinética da liberação de ciprofloxacina. As curvas obtidas são mostradas no apêndice 3 e os modelos matemáticos utilizados são mostrados no Anexo 1 , com os valores de coeficiente de determinação mostrados na Tabela 6. 
Tabela 6 - Coeficiente de determinação para cada modelo de liberação de fármaco

\begin{tabular}{lc}
\hline \multicolumn{1}{c}{$\begin{array}{c}\text { Modelo de liberação } \\
\text { de fármaco }\end{array}$} & $\mathbf{R}^{2}$ \\
\hline Primeira ordem & 0,4971 \\
Segunda ordem & 0,4631 \\
Hixson-Crowell & 0,6579 \\
Korsmeyer-Peppas & 0,9093 \\
Weibull & 0,9847 \\
\hline
\end{tabular}

O modelo com o maior ajuste linear dos dados $\left(R^{2}\right.$ mais próximo a 1) foi o modelo de Weibull (Equação 10). Neste modelo, a fração cumulativa de fármaco liberado $\left(\mathrm{M}_{\mathrm{t}} / \mathrm{M}_{0}\right)$ é descrita pela Equação 10. Na qual b e a são parâmetros que indicam a forma da curva (exponencial, sigmoide ou parabólica) e a escala de tempo da liberação, respectivamente (COSTA; LOBO, 2001).

$$
\log _{10}\left[-\ln \left(1-\mathrm{M}_{\mathrm{t}} / \mathrm{M}_{0}\right)\right]=\mathrm{b} \times \log _{10}(\mathrm{t})-\log _{10}(\mathrm{a})
$$

Para a liberação de ciprofloxacina o valor de $b$ no modelo de Weibull foi igual a 1,84 , que corresponde a uma curva sigmoide de curvatura ascendente seguida de um ponto de inflexão (COSTA; LOBO, 2001).

O modelo de Weibull e útil para a descrição e comparação dos dados de liberação, porém não é derivado de nenhuma lei física, nem contém nenhum parâmetro cinético referente à dissolução do fármaco. Mas, de acordo com Vasiliki et al. (2015) os valores de b podem ser associados a mecanismos de liberação por difusão do fármaco. Segundo estes autores o valor de $\mathrm{b}>1$ indica que o sistema tem um mecanismo de liberação complexo. Então a liberação da ciprofloxacina pelas membranas PVA/C24/Cpx segue um mecanismos de liberação complexo, no qual, estariam envolvidos a difusão, o intumescimento e a erosão da matriz polimérica (CARBINATTO et al., 2014).

\subsection{Estudo da matriz polimérica PVA/C24}

As interações entre os dois polímeros foram estudadas nas membranas de PVA/C24, as quais podem ser consideradas a matriz polimérica dos sistemas de liberação selecionados. 


\subsubsection{Calorimetria Exploratória Diferencial (DSC)}

As membranas de PVA/C24 e C24 foram caracterizadas por DSC. As curvas DSC (Figura 16) permitiram a determinação dos eventos de desnaturação térmica do colágeno nas membranas. A desnaturação do colágeno pode ser entendida como a transição da estrutura de hélice tripla para uma conformação espacialmente desordenada, estimulada por fatores como aquecimento, presença de ácidos, álcoois ou outros agentes (BADEA et al., 2008). Quando o fator é o aquecimento, acontece a quebra de ligações intramoleculares e a proteína passa de uma estrutura altamente organizada a um estado aleatório, denominado gelatina (ARNOCZKY; AKSAN, 2000). A temperatura a qual acontece este evento térmico é denominada temperatura de desnaturação do colágeno $\left(T_{d}\right)$.

Figura 16 - Curvas DSC das membranas de PVA/C24 (-) e C24 (-), com uma razão de aquecimento de $10^{\circ} \mathrm{C} \mathrm{min}^{-1}$, em atmosfera de nitrogênio.

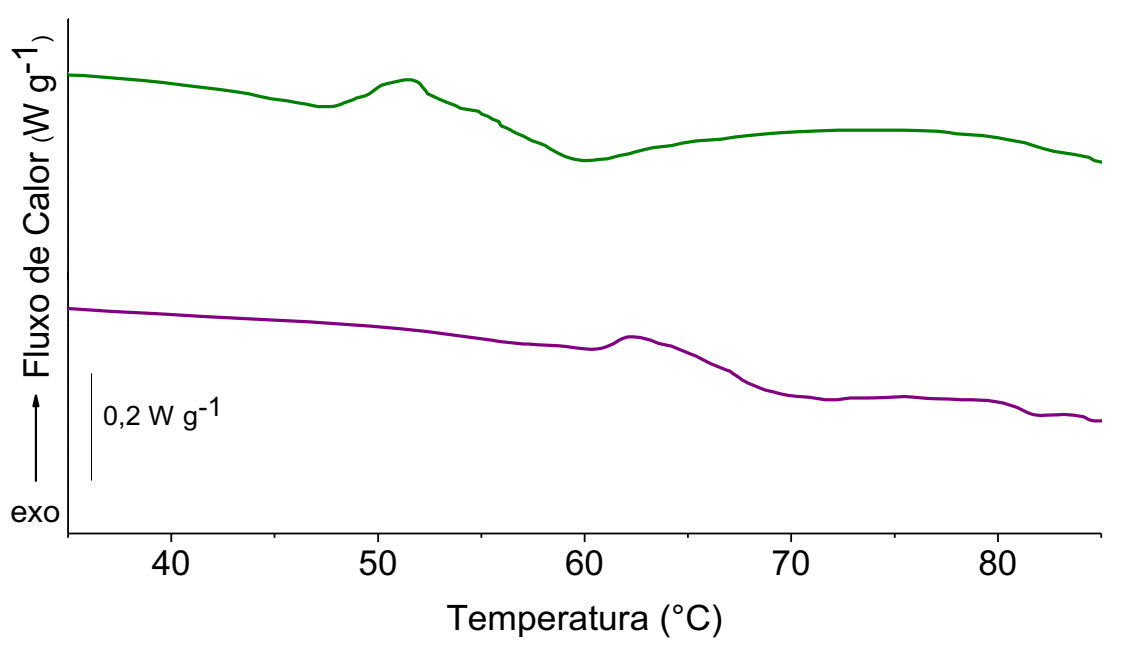

A $T_{d}$ das membranas de C24 e PVA/C24 foi 57,8 e $67,3{ }^{\circ} \mathrm{C}$, respectivamente (Figura 16). $\mathrm{O}$ aumento da $T_{d}$ significa que a presença do PVA estabilizou a estrutura de hélice tripla das macromoléculas de colágeno. Uma possível explicação para isto é, que na $T_{d}$, as cadeias polipeptídicas do colágeno têm uma suficiente mobilidade para se desprender da hélice tripla e se dispersar na matriz de C24 formando novas interações moleculares com as cadeias polipeptídicas contíguas. Já no caso da matriz de PVA/C24 as cadeias polipeptídicas não têm a mesma facilidade para se movimentar por causa da presença do PVA e precisam de maior energia para se desprender da hélice tripla (aumento da $T_{d}$ ). 
$\mathrm{Na}$ analise por DSC não foi incluída a membrana de PVA devido a que este polímero não apresenta eventos térmicos na faixa de temperaturas testada (SUDHAMANI; PRASAD; SANKAR, 2003).

\subsubsection{Espectroscopia no Infravermelho com transformada de Fourier} (FTIR)

Nos espectros FTIR das membranas de PVA/C24 e C24 (Figura 17) foram observadas as bandas de absorção em 1658, 1235 e $1450 \mathrm{~cm}^{-1}$ características do colágeno nativo. A banda a $1658 \mathrm{~cm}^{-1}$ é associada à deformação axial da ligação $\mathrm{C}=\mathrm{O}$ (amida I), a banda a $1235 \mathrm{~cm}^{-1}$ corresponde à vibração no plano da ligação $\mathrm{C}-\mathrm{N}$ (amida III) e o estiramento da ligação N-H (amida I), e a banda a $1450 \mathrm{~cm}^{-1}$ corresponde à vibração dos anéis pirrolidínicos de prolinas e hidroxiprolinas. No espectro das membranas PVA/C24 também se observaram as bandas a 3300, 2940 e $1090 \mathrm{~cm}^{-1}$ características do PVA puro, e que são associadas aos estiramentos $\mathrm{O}-\mathrm{H}$, aos estiramentos simétricos e assimétricos dos $\mathrm{CH}_{2}$ e ao estiramento do C-O respectivamente (HASSIBA et al., 2017).

Figura 17 - Espectros FTIR das membranas de PVA (-), C24 (-) e PVA/C24 (-).

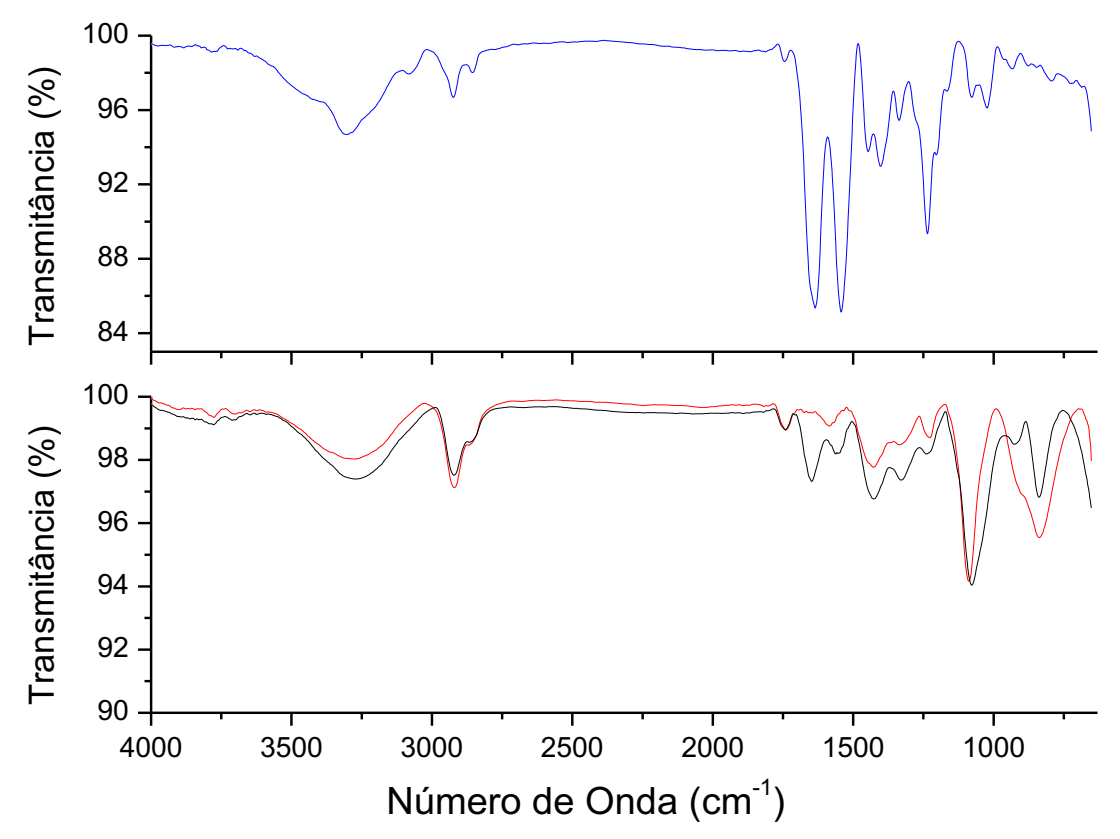

A relação entre as intensidades das bandas a 1235 e $1450 \mathrm{~cm}^{-1}$ é um indicativo da integridade da estrutura secundária do colágeno (BET; GOISSIS; LACERDA, 2001). Para as membranas de PVA/C24 e C24 o valor de $1235 / 1450 \mathrm{~cm}^{-1}$ foi de 1,0 indicando que o colágeno nestes materiais conservou sua 
hélice tripla integra, apesar de ter sido submetido a hidrólise alcalina e a mistura com o PVA.

A espectroscopia FTIR e uma ferramenta útil para estudar a miscibilidade entre polímeros. As interações intermoleculares entre dois polímeros são registradas nos espectros de FTIR como deslocamentos nas frequências de vibração características de cada polímero puro. De acordo com Sionkowska, Skopińska e Wisniewski (2004) pequenos deslocamentos nas frequências de vibração das amidas I e II do colágeno indicam pequenas interações entre o PVA e o colágeno nativo provavelmente pela formação de ligações de hidrogênio entre eles. Porém, estas interações levam à miscibilidade entre os dois polímeros somente para concentrações baixas de PVA ( 1\%). A maiores concentrações de PVA, a formação de ligações de hidrogênio entre os dois polímeros compete com a formação de ligações de hidrogênio entre as moléculas do mesmo polímero. Analogamente, a ausência de deslocamentos nas bandas das membranas de PVA/C24 em relação às bandas das membranas de C24 e PVA (Figura 17) é indicativo de que o PVA e o colágeno aniônico são imisciveis à concentração estudada.

\subsubsection{Termogravimetria}

A termogravimetria foi usada para determinar a estabilidade térmica da matriz de PVA/C24 com relação aos polímeros puros. Nas curvas termogravimétricas e nas curvas DTG (Figura 18) se observaram quatro estágios de perda de massa para as membranas de PVA e três estágios de perda de massa para as membranas de C24 e PVA/C24. A Tabela 7 se reúne os dados quantitativos desses estágios de degradação térmica.

Nas curvas termogravimétricas se observou que no primeiro estágio de aquecimento das membranas de PVA/C24 a perda de água foi menor do que a perda de água nas $\mathrm{C} 24$.

Além disso, na curva de DTG se observou que a temperatura de maior velocidade de perda de água das membranas de PVA/C24 foi maior à da membrana de C24 e próxima à do PVA puro, devido provavelmente à maior proporção de PVA na composição da blenda e a sua alta afinidade pela água. 
Figura 18 - Curva termogravimétrica e curva DTG das membranas de PVA (-), C24 (-) e PVA/C24 (-) em atmosfera de Nitrogênio.
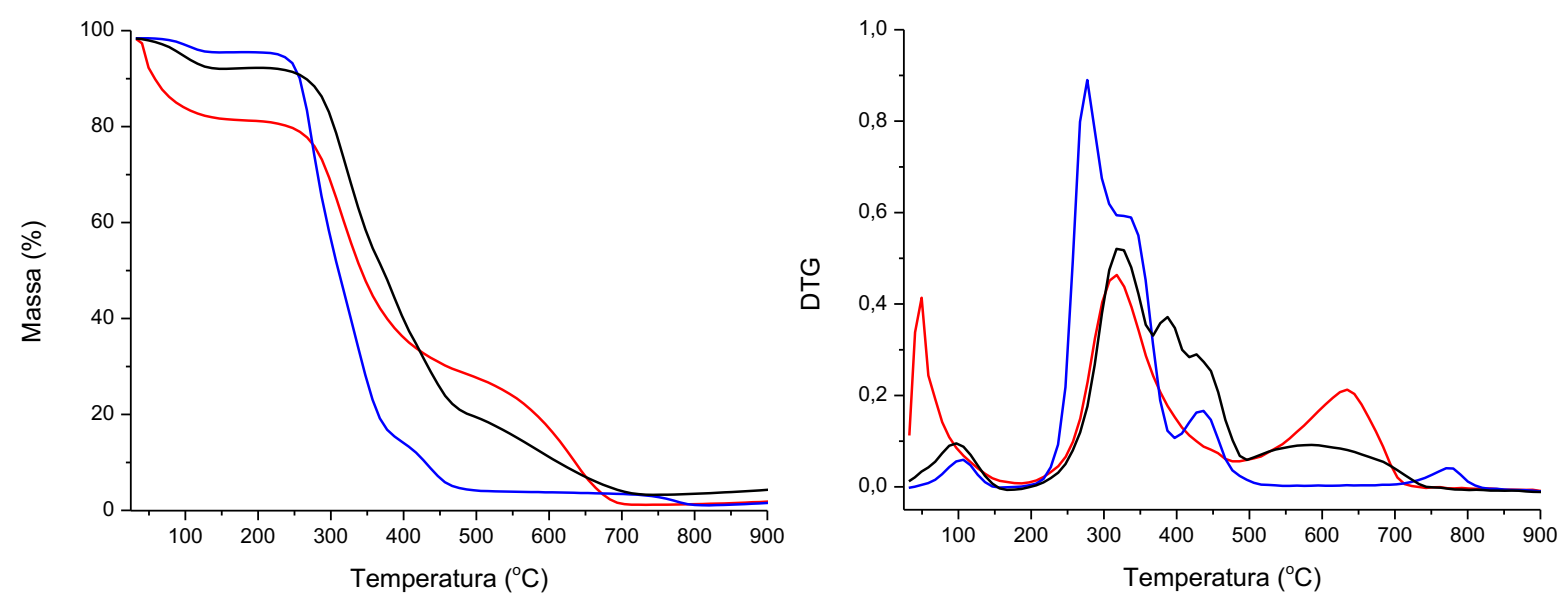

Tabela 7 - Eventos térmicos e porcentagens de perda de massa correspondentes aos estágios de degradação térmica das membranas de C24, PVA e PVA/C24

\begin{tabular}{cccc}
\hline Membrana & $\begin{array}{c}\text { Faixa de } \\
\text { temperatura }\left({ }^{\circ} \mathbf{C}\right)\end{array}$ & $\begin{array}{c}\text { \% perda de } \\
\text { massa }\end{array}$ & Evento térmico \\
\hline C24 & $30-200$ & 18,9 & Perda de água estrutural \\
& $200-500$ & 53,8 & Decomposição colágeno \\
& $500-900$ & 25,5 & Carbonização \\
PVA & $30-200$ & 4,6 & Perda de água \\
& $200-400$ & 91,3 & Degradação de ligações \\
& $500-900$ & 2,4 & Carbonização \\
PVA/C24 & $30-200$ & 7,8 & Perda de água \\
& $200-500$ & 73,2 & Decomposição dos polímeros \\
& $500-900$ & 14,6 & Carbonização \\
\hline
\end{tabular}

${ }^{1}$ (YANG et al., 2012)

No segundo estágio o comportamento térmico das membranas de PVA/C24 é mais parecido com o comportamento térmico da C24. As duas classes de membranas começaram a degradar a uma temperatura de aproximadamente $266{ }^{\circ} \mathrm{C}$, enquanto que a decomposição térmica do PVA começou em aproximadamente $246^{\circ} \mathrm{C}$, indicando que a PVA/C24 é mais estável termicamente do que o PVA. Está estabilização térmica pode ser considerada como evidencia de uma interação entre os polímeros. Por outro lado, devido à decomposição do PVA e do 
colágeno aniônico acontecerem dentro da mesma faixa ampla de temperatura (200 a $500^{\circ} \mathrm{C}$ ) não foi possível calcular a perda de massa correspondente a cada polímero dentro das membranas de PVA/C24.

Após $800{ }^{\circ} \mathrm{C}$ não se observa mais perda de massa nas curvas termogravimétricas, o que indica a presença de resíduos (menos de $2 \%$ em massa para as membranas de C24 e PVA, e menos de 4\% em massa para as membranas de PVA/C24). Estes resíduos podem ser sais inorgânicas (cloretos, sulfatos, etc.) remanescentes ao processo de obtenção dos polímeros, que nas quantidades presentes, não representariam um risco para a saúde do paciente.

\subsection{Estudo dos sistemas de liberação selecionados}

\subsubsection{Morfologia de superfície e seção transversal}

As propriedades das blendas dependem principalmente da sua morfologia. Entre as características morfológicas mais importantes a estudar nas blendas estão a sua miscibilidade e seu comportamento de fases (THOMAS; GROHENS; JYOTISHKUMAR, 2014).

A morfologia de superfície e de seção transversal das membranas selecionadas na liberação in vitro (PVA/C24/Cpx e PVA/C24/Tb), a membrana de PVA/C24 e as membranas de referencia (PVA e C24) foram estudadas usando MEV.

Na Figura 19 se observa que a superfície das membranas C24, PVA/C24, $\mathrm{PVA} / \mathrm{C} 24 / \mathrm{Tb}$ foi heterogênea e sem poros. Além disso, as superfícies das membranas de PVA/C24/Tb e PVA/C24 foram similares, o que indica que a tobramicina foi completamente dissolvida pela matriz polimérica. 
Figura 19 - Micrografias de superfície das membranas A - C24, B - PVA. C - PVA/C24 e D - PVA/C24/Tb.
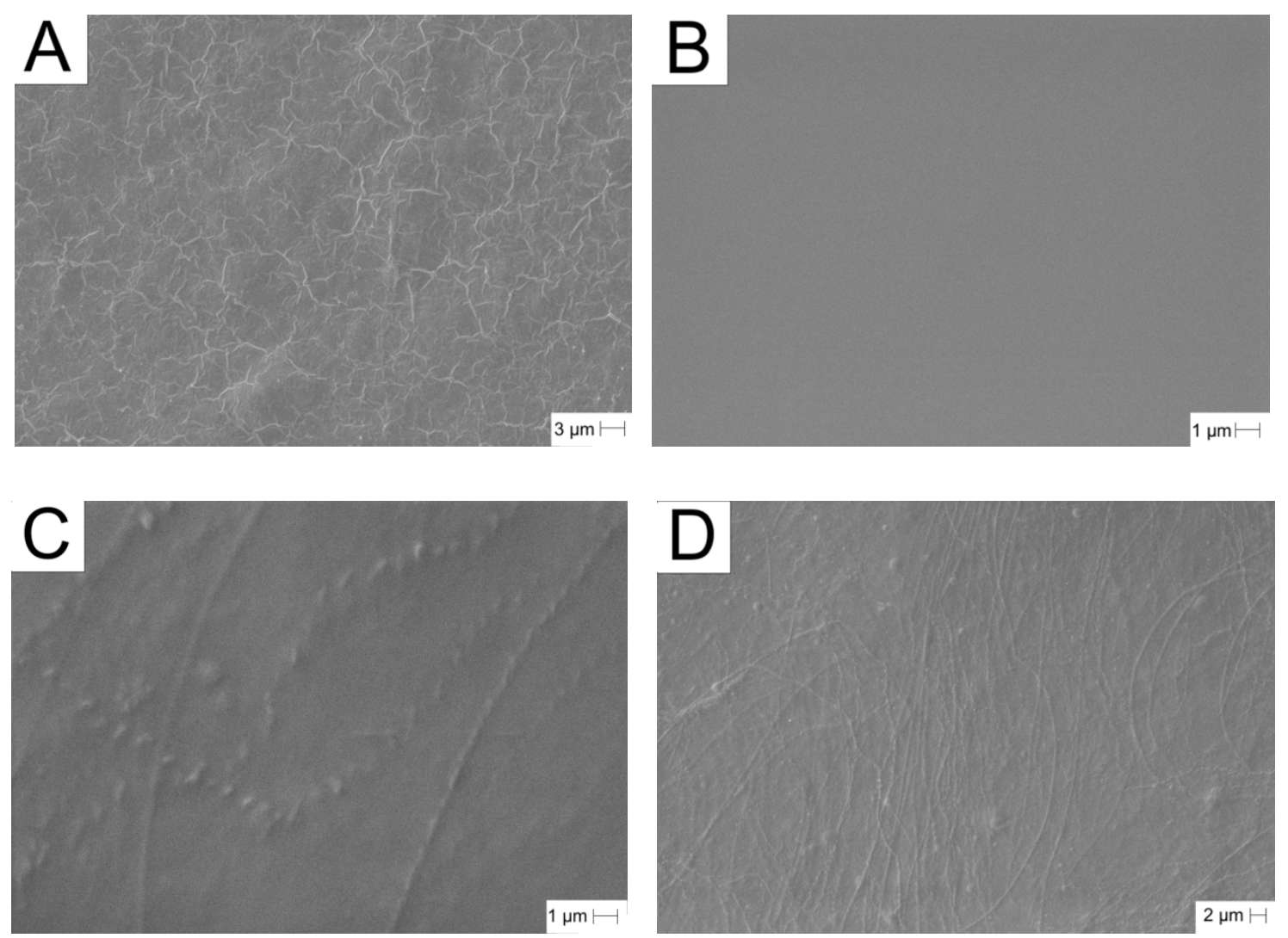

A presença de fibrilas distribuídas aleatoriamente na superfície das membranas de PVA/C24 confirma a imiscibilidade dos polímeros. Mas, apesar de serem imiscíveis no PVA, as fibrilas de colágeno aniônico estão totalmente dispersas através da superfície, característica devida à dispersão dos polímeros em estado líquido durante a obtenção das blendas. Com base nesta observação, as membranas de PVA/C24 podem ser interpretadas como matrizes poliméricas de dois domínios, onde o domínio de menor proporção (colágeno aniônico) está disseminado aleatoriamente através do segundo domínio (PVA). Esta forma de ver estas membranas será útil para entender o seu comportamento mecânico, a hidrofilicidade da sua superfície, a sua estabilidade dimensional e a sua rugosidade (items 5.6.2, 5.6.5, 5.6.7 e 5.6.10).

$\mathrm{Na}$ figura 20 são apresentadas as secções transversais das membranas de C24, PVA, PVA/C24 e PVA/C24/Tb. 
Figura 20 - Micrografias de seção transversal das membranas A - C24, B - PVA, C - PVA/C24 e D - PVA/C24/Tb.
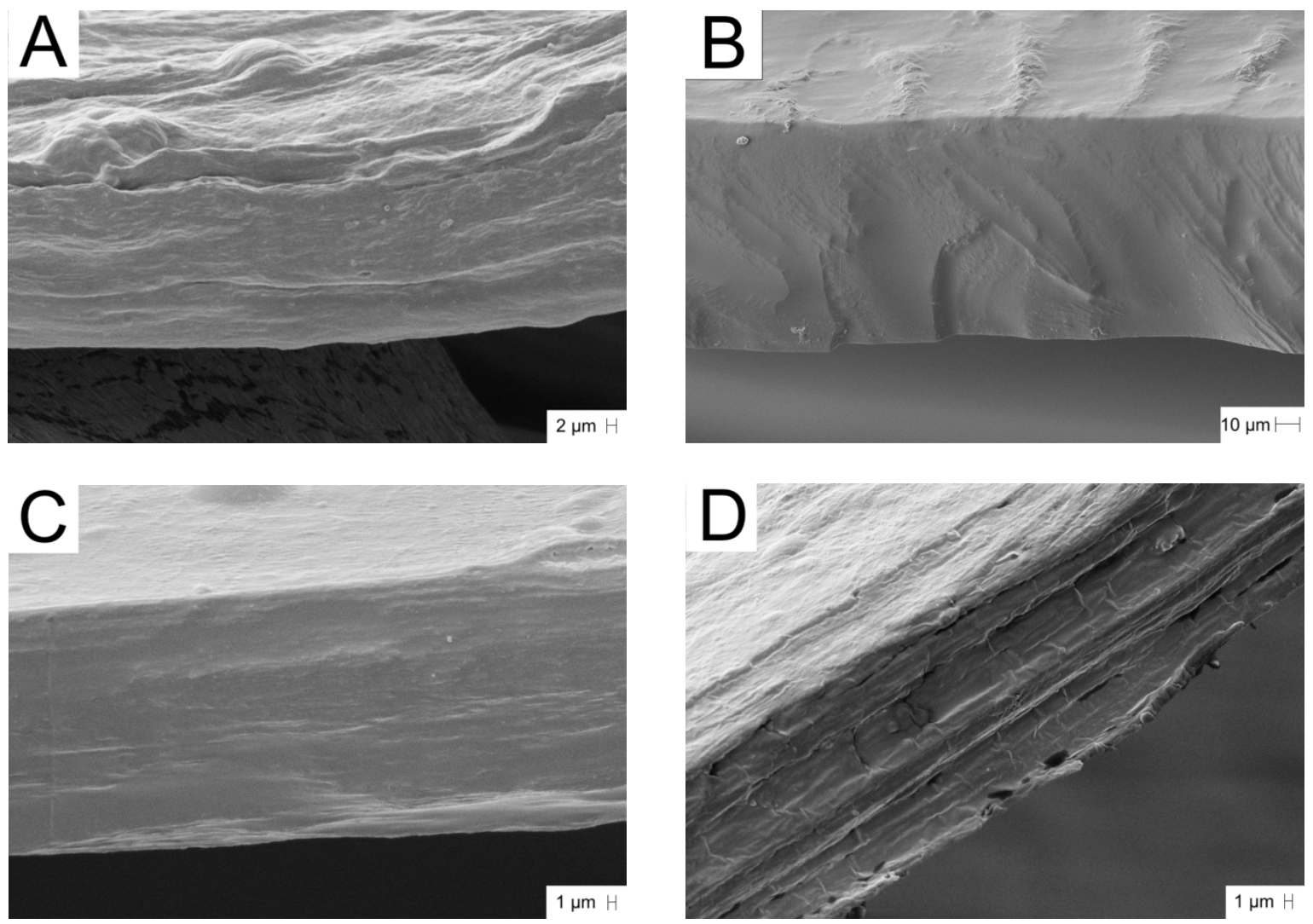

A morfologia da seção transversal das membranas de PVA/C24 (Figura 20C) se mostrou densa, sem aglomerados e uniforme, de maneira semelhante ao que foi observado para os polímeros separados (Figuras 20A e 20B), como era de se esperar devido à dispersão do colágeno no PVA. Entretanto, a seção transversal da membrana de PVA/C24/Tb (Figura 20D) teve um aspecto fibroso e não uniforme. Este tipo de morfologia foi formada durante a incorporação da tobramicina, devido provavelmente à solubilização parcial do PVA (ver item 5.6.9) e à posterior reorganização das moléculas de colágeno aniônico durante a secagem da membrana (após a absorção de tobramicina).

A superfície das membranas de PVA/C24/Cpx apresenta uma morfologia muito particular (Figura 21A), coberta de cristais de ciprofloxacina em forma de agulhas, que dão a coloração amarela a estas membranas. 
Figura 21 - Micrografias de superfície das membranas A - PVA/C24/Cpx e B - PVA/C24/Cpx após liberação da Cpx por $48 \mathrm{~h}$ em PBS.
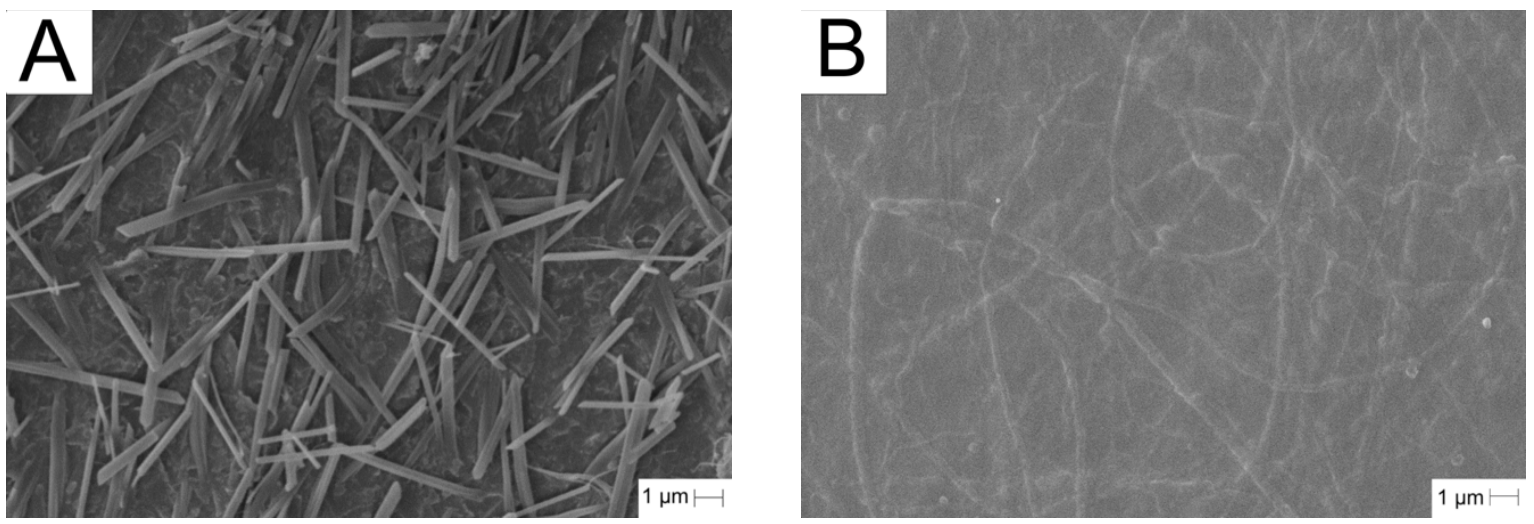

Em lentes de contato a precipitação de ciprofloxacina sob a superfície foi relatada previamente por alguns autores (CIOLINO et al., 2011; GARHWAL et al., 2012). Segundo Nguyen et al. (2012) a precipitação de ciprofloxacina sobre a lente pode reduzir as propriedades óticas do dispositivo, mas não interfere com o tratamento, e este mesmo raciocínio pode ser aplicado para as membranas de PVA/C24/Cpx.

Ao observar a seção transversal das membranas de PVA/C24/Cpx (Figura 22A) se pode perceber como se dá a separação de domínios através da espessura do material.

Figura 22 - Micrografias de seção transversal das membranas A - PVA/C24/Cpx e B - PVA/C24/Cpx após liberação da Cpx por 48 h em PBS.
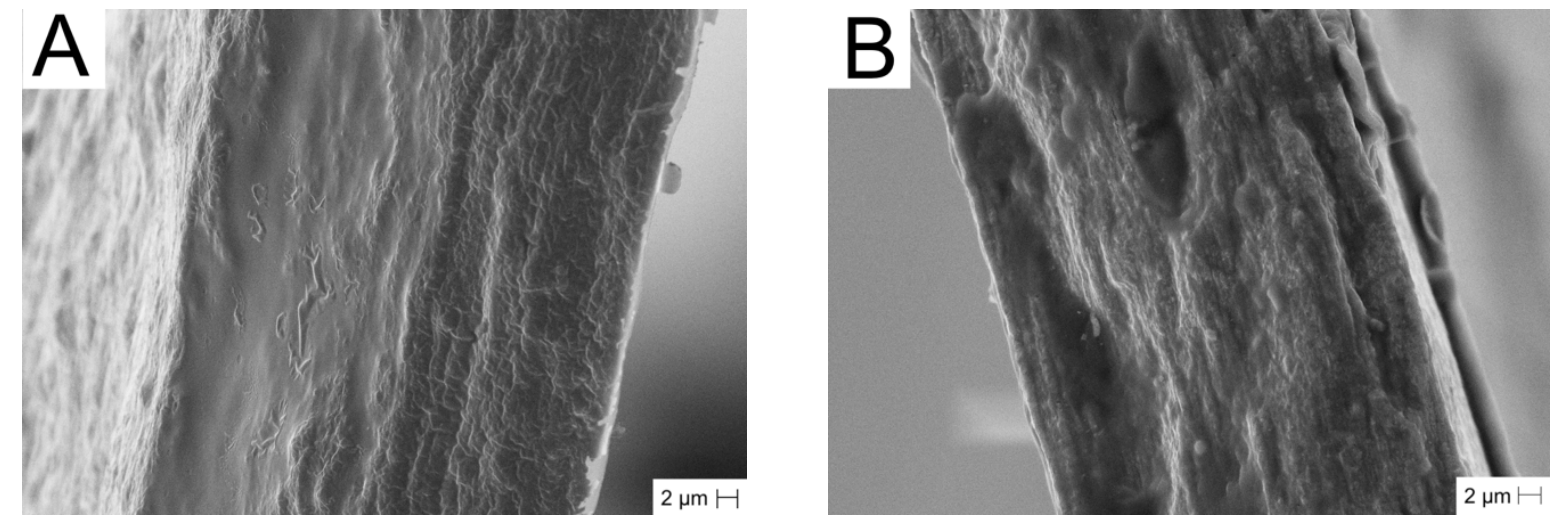

Essa separação de domínios na membrana de PVA/C24/Cpx indica que, durante a formação desta blenda, um domínio fibroso (composto principalmente de colágeno) se acumula no lado mais próximo ao molde de Teflon, enquanto um domínio mais uniforme e denso (composto principalmente de PVA) se acumula do 
outro lado. Esta disposição de domínios pode ser o motivo da opacidade desta membrana, e pode ter sido originada pela solubilidade da ciprofloxacina em cada domínio. Isto porque, ao ter um grupo carboxílico, a ciprofloxacina tem tendência a interagir mais com o PVA (através da formação de ligações de hidrogênio) do que com o colágeno aniônico (MABROUK et al., 2014). Este fato favorece a formação de um domínio abundante em PVA onde se estabiliza a ciprofloxacina, e outro domínio com menor conteúdo de PVA e ciprofloxacina originado pela segregação do colágeno aniônico. Ao final deste processo, a ciprofloxacina é distribuída de forma heterogênea através da seção transversal do material, o que por sua vez, poderia explicar a liberação estendida de ciprofloxacina observada no item 5.3.

Por último, foi estudada a morfologia das membranas de PVA/C24/Cpx após a liberação da ciprofloxacina. Na Figura 21B se observa que os cristais de ciprofloxacina foram removidos da superfície destas membranas e as fibrilas de colágeno são agora observáveis. Por outro lado, a estrutura da seção transversal destas membranas apresenta sulcos (Figura 22B), devido à liberação do antibiótico e à erosão/dissolução dos polímeros (bulk erosion). Estes dois eventos ocasionam uma diminuição do 7,6\% na espessura da membrana de PVA/C24/Cpx após o período de liberação do antibiótico. Kolakovic et al. (2012) também observaram a aparição de porosidade na morfologia da seção transversal de matrizes de celulose nanofibrilar após a liberação de indometacina. Para lentes de contato e escudos de colágeno não foram encontrados relatos na literatura com respeito a este aspecto.

\subsubsection{Rugosidade}

A rugosidade é uma das características da superfície que mais influi na aplicação de um biomaterial. Quanto mais rugoso um material, maior é sua área superficial e maior o número de sítios ativos para que aconteçam reações biológicas, tais como a adesão proteica e a adesão celular (STYLIANOU; YOVA; ALEXANDRATOU, 2014).

A rugosidade das membranas foi estudada em escala nanométrica usando a Microscopia de Força Atômica. Na Figura 23 se observa que a superfície do PVA é a mais lisa, enquanto que a superfície das membranas contendo colágeno é rugosa. Por sua vez, a membrana $\mathrm{C} 24$ foi a mais rugosa (Tabela 8). A rugosidade em blendas de PVA e colágeno nativo foi estudada por Sionkowska et al. (2009). Segundo os autores, a rugosidade destas blendas aumenta com o incremento na 
concentração de colágeno (de $1 \%$ para $3 \%$ em massa) e isto foi associado à estrutura fibrosa do colágeno tipo I. Em congruência com esse estudo, na Figura 23 se observa que a rugosidade das blendas é originada pela presença de fibrilas de colágeno aniônico que criam diferenças entre as alturas na superfície.

Figura 23 - Perspectiva tridimensional da topografia das membranas de A - C24, B - PVA, C - PVA/C24, D - PVA/C24/Tb, E - PVA/C24/Cpx e F - PVA/C24/Cpx após a liberação da ciprofloxacina por $48 \mathrm{~h}$ em PBS.

A

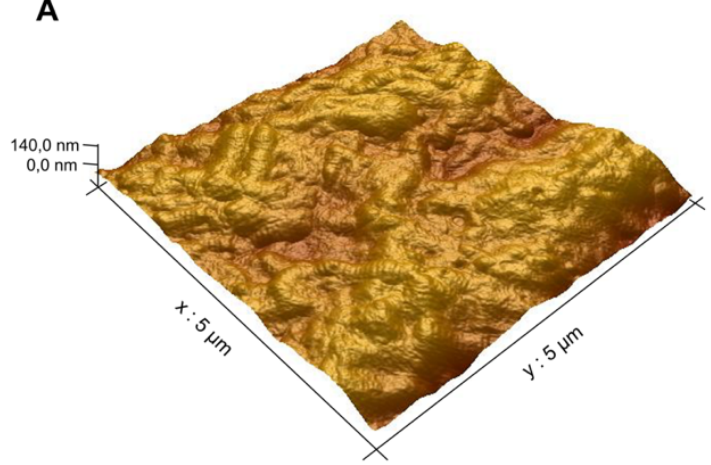

C
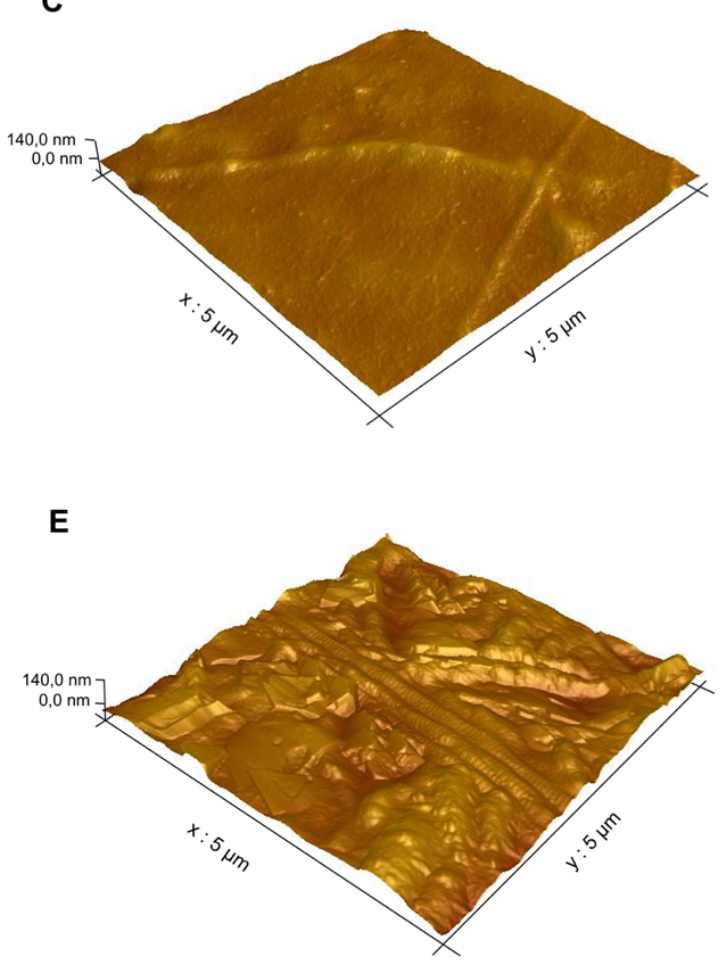

B
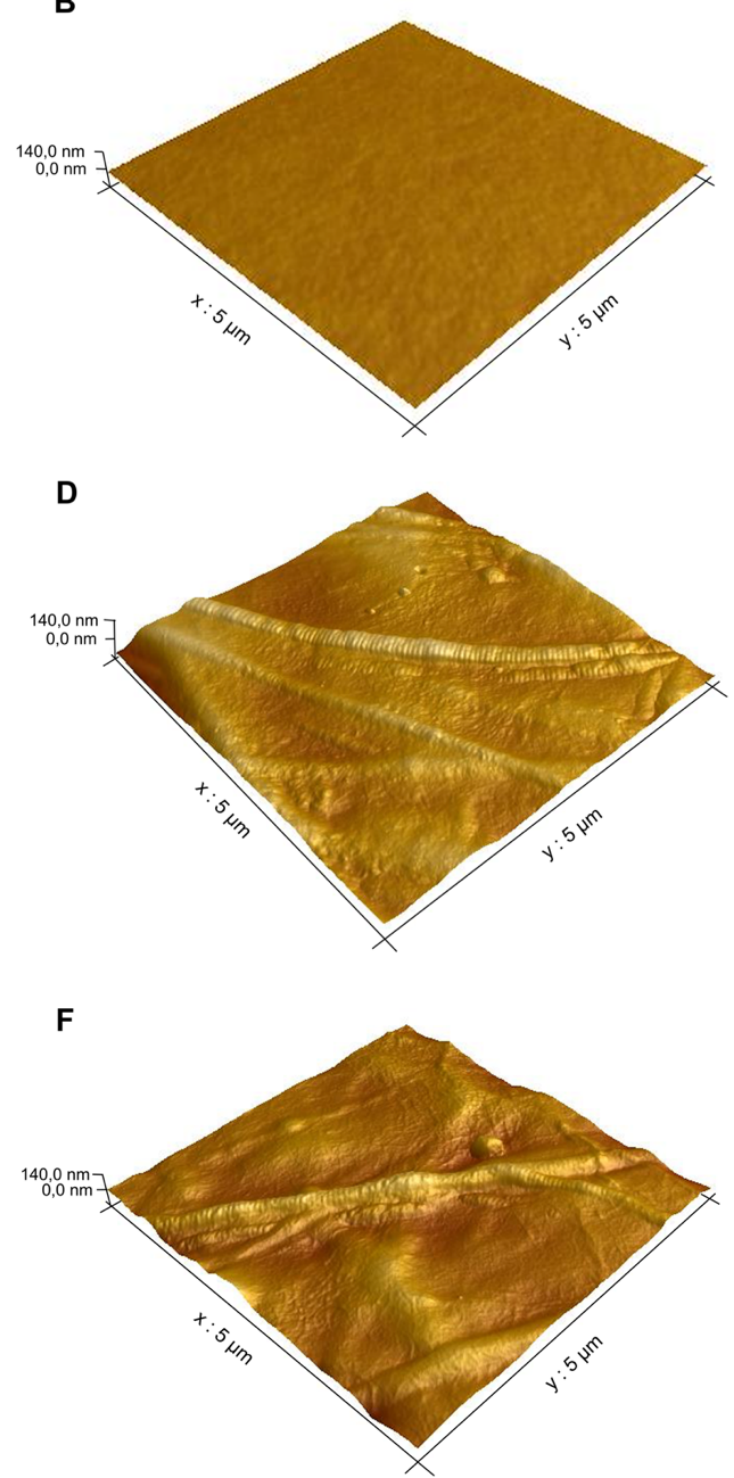
Tabela 8 - Valores de rugosidade média $\left(R_{a}\right)$ e Desvio médio quadrático $\left(R_{\mathrm{q}}\right)$ para as membranas, calculados para uma área superficial de $25 \mu \mathrm{m}^{2}$

\begin{tabular}{ccc}
\hline \multicolumn{1}{c}{ Membrana } & $\mathbf{R}_{\mathbf{a}}$ & $\mathbf{R}_{\mathbf{q}}$ \\
\hline C24 & $38 \pm 6$ & $47 \pm 6$ \\
PVA/C24 & $12 \pm 1$ & $16 \pm 2$ \\
PVA/C24/Cpx & $29 \pm 3$ & $37 \pm 4$ \\
PVA/C24/Tb & $18 \pm 3$ & $23 \pm 3$ \\
PVA/C24/Cpx & $17 \pm 3$ & $22 \pm 4$ \\
PVA & $1,56 \pm 0,08$ & $1,96 \pm 0,08$ \\
& ${ }^{1}$ Após a liberação do antibiótico em PBS por $48 \mathrm{~h} \mathrm{e} \mathrm{a} 37^{\circ} \mathrm{C}$.
\end{tabular}

Em lentes de contato, uma maior rugosidade está relacionada com uma maior tendência à adesão microbiana (GIRALDEZ; YEBRA-PIMENTEL, 2012). Isto porque, nas irregularidades de uma lente rugosa se podem formar depósitos de exudatos ou detritos, onde os microrganismos encontram o ambiente favorável para se aderir. Além disso, a adesão bacteriana também é dependente da hidrofobicidade da lente de contato. Giraldez e Yebra-Pimentel (2012) determinaram a adesão de $P$. aeruginose e $S$. epidermis na superfície de lentes de contato macias e concluíram que as lentes hidrofóbicas de baixa rugosidade como Senofilcon $A(R q=4,06 \pm$ 0,38 ) aderiram um maior número de colônias bacterianas comparadas com as lentes hidrofilicas de alta rugosidade como Nefilcon $A(R q=15,41 \pm 1,26)$ e Ocufilcon $B$ $(\mathrm{Rq}=14,38 \pm 2,13)$.

Por outro lado, em escudos de colágeno, que são materiais feitos exclusivamente com colágeno como a membrana $\mathrm{C} 24$, não há relato de adesão microbiana devido à rápida degradação do material na superfície ocular (WILLOUGHBY; BATTERBURY; KAYE, 2002). Isto pode indicar que, mesmo que a membrana C24 seja mais rugosa do que as membranas de PVA/colágeno aniônico, não significa necessariamente que vai ter uma maior adesão microbiana.

$O$ fato de que as membranas obtidas no presente estudo foram mais rugosas do que as lentes de contato estudadas por Giraldez e Yebra-Pimentel (2012), alerta sob a possibilidade de ter adesão microbiana nestes materiais. Porém, existem três fatores importantes que desfavoreceriam a deposição bacteriana sob estes materiais: 1) A degradação continua do colágeno na superfície do material, 2) 
A alta hidrofilicidade e erosão do PVA, e 3) a liberação do antibiótico. Contudo, é necessário testar a adesão microbiana das blendas, especialmente quando se pretende usar estes materiais por um tempo superior ao período de liberação dos antibióticos.

Ao contrário do que pode ser considerado, a rugosidade poderia ser uma boa característica para as membranas de PVA/colágeno aniônico, uma vez que entre maior a rugosidade maior a superfície de contato entre o material e o fluido pré-corneal, e consequentemente maior a quantidade de fármaco difundido em direção à córnea (maior biodisponibilidade) em relação a materiais menos rugosos como às lentes de contato e membranas de PVA.

Por último, se observou que após a liberação da ciprofloxacina as membranas de PVA/C24/Cpx reduzem sua rugosidade. Esta variação na rugosidade certamente aconteceu pela dissolução do antibiótico na superfície, mas também pela erosão superficial do material. Porém, devido a rugosidade ter sido reduzida até um valor próximo à rugosidade das membranas de PVA/C24/Tb, se intui que a erosão superficial não foi o principal evento de degradação do material e sim a erosão em massa (bulk erosion) como se observou no item 5.6.1.

\subsubsection{Fibrilas de colágeno aniônico}

Usando a AFM foi possível analisar a estrutura tridimensional das fibrilas de colágeno aniônico. Na Figura 24 se observa que na superfície das membranas de PVA/colágeno aniônico algumas fibrilas foram revestidas pelo PVA, enquanto outras ficaram expostas exibindo a estrutura tubular com bandas periódicas (período D) características do colágeno nativo. Porém, o distanciamento entre os gaps para o colágeno aniônico foi de $\sim 59 \mathrm{~nm}$ (Figura 25), que é menor ao valor de $67 \mathrm{~nm}$ relatado para as fibrilas de colágeno nativo (STYLIANOU; YOVA; ALEXANDRATOU, 2013). Isto é devido a que durante a hidrólise alcalina, o colágeno perde uma parte das suas reticulações naturais, o que ocasiona desdobramento local da hélice tripla e redução da periodicidade $\mathrm{D}$, sem a destruição da estrutura fibrilar (HULMES, 2008). 
Figura 24 - Imagens bidimensionais da topografia das membranas de A - C24, B - PVA, C - PVA/C24, D - PVA/C24/Tb, E - PVA/C24/Cpx e F - PVA/C24/Cpx após a liberação da ciprofloxacina por 48h.
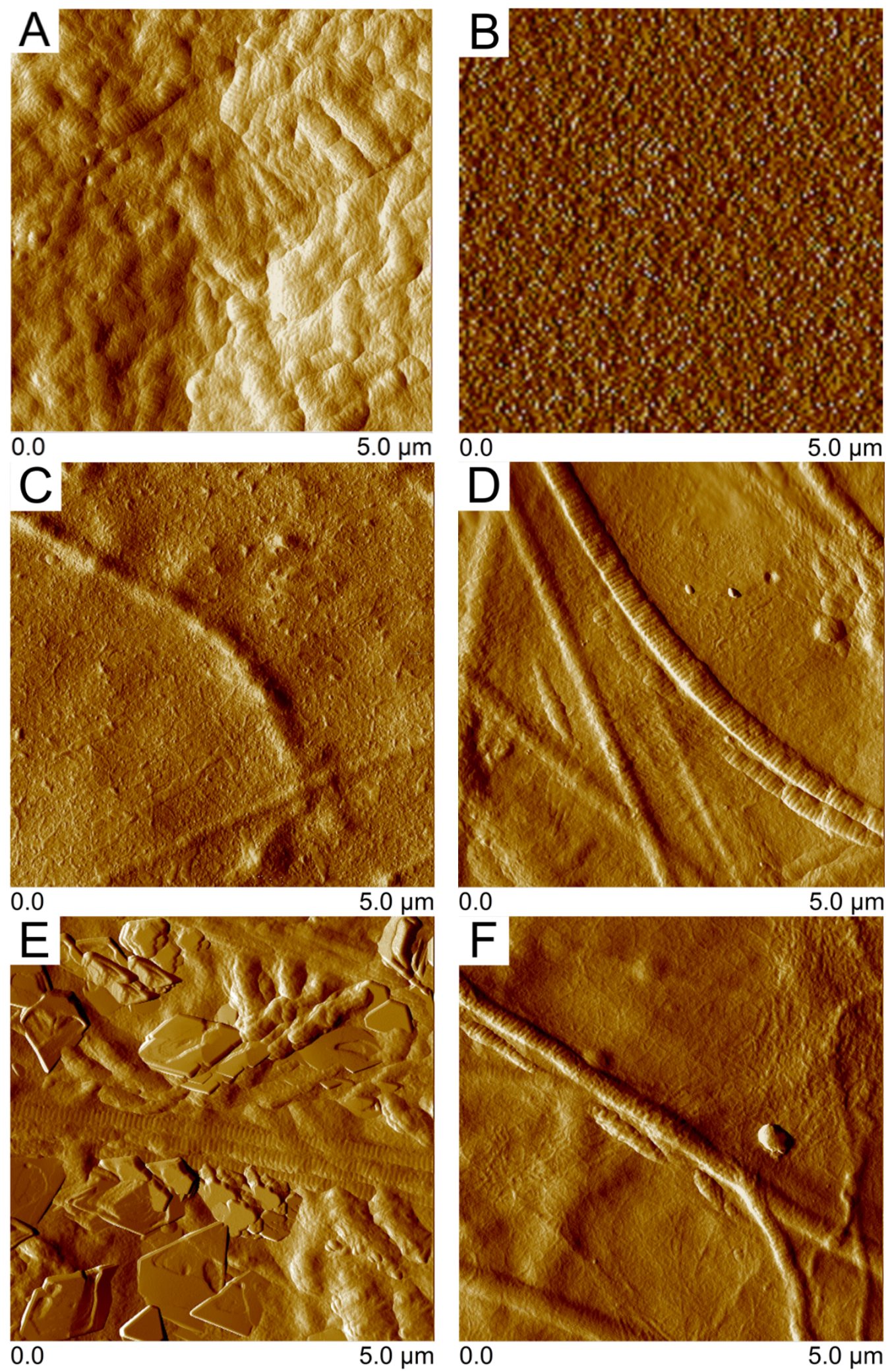
Figura 25 - Distância entre gaps para a fibrila de colágeno aniônico presente na superfície da membrana PVA/C24/Tb.
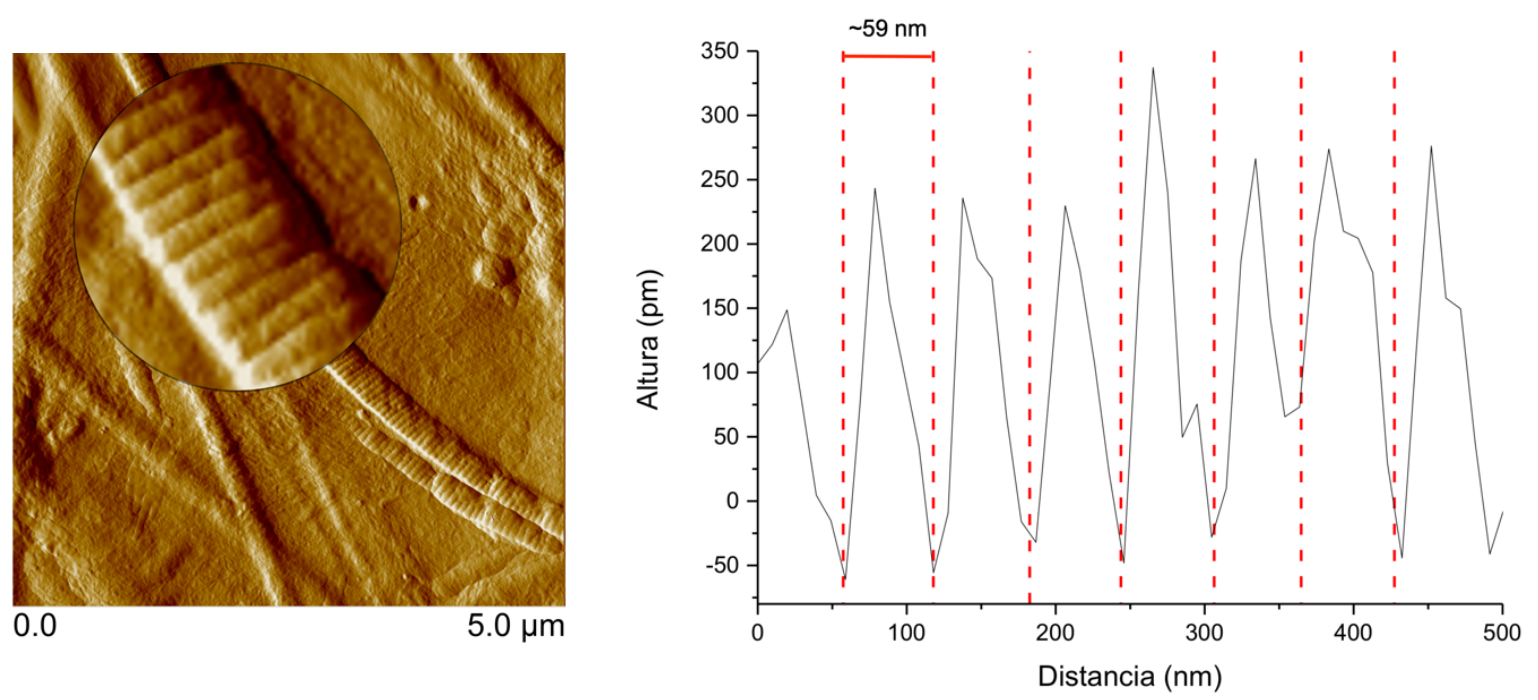

As fibrilas "nuas" na superfície das blendas são locais onde pode iniciar a sua degradação enzimática. Segundo Fleck e Simman (2010) a elastase e as metaloproteinases de matriz (que são enzimas responsáveis pela cronicidade das feridas) têm afinidade pela estrutura de hélice tripla do colágeno. Esta afinidade tem sido observada para todos os materiais a base de colágeno e contribui a reduzir a destruição da matriz extracelular durante o processo inflamatório da ferida. É assim como, a ação destes dois tipos de enzimas sobre as fibrilas de colágeno "nuas" na superfície das blendas poderia reduzir a destruição da córnea, favorecendo então, o processo de regeneração tecidual de modo similar ao que acontece com os escudos de colágeno (WILLOUGHBY; BATTERBURY; KAYE, 2002). Mas, diferentemente dos escudos de colágeno, a presença do PVA nas blendas reduziria a possibilidade de fragmentação prematura das membranas por causa da degradação enzimática do material durante a aplicação.

\subsubsection{Intumescimento e conteúdo de água das membranas}

O grau de intumescimento e o conteúdo de água são duas formas de representar a capacidade de absorção de água do material. O grau de intumescimento representa a quantidade de água absorvida com relação à massa seca do material e o conteúdo de água representa a porcentagem de água contida no material hidratado. Embora, em oftalmologia é muito mais usado o conteúdo de água para apresentar a absorção de água dos materiais, neste estudo são 
apresentados os dois parâmetros para efeitos de análise e comparação dos resultados.

$\mathrm{Na}$ Figura 26 se observa que todas as membranas absorveram água rapidamente durante o primeiro minuto chegando ao intumescimento total em 40 min. A absorção de água por parte das membranas contendo PVA foi superior à absorção de água das membranas de C24. Isto pode ser devido ao aumento no número de grupos hidrofilicos nas membranas de PVA/C24, PVA/C24/Tb e PVA/C24/Cpx como resultado da introdução do PVA na matriz polimérica. O grau de intumescimento destas membranas também foi de 3 a 4 vezes superior ao obtido por Jain et al. (2011) para insertos oculares de PVA e gelatina.

Figura 26 - Curvas de porcentagem de absorção de PBS das membranas de PVA (-), C24 (—), PVA/C24 (-), PVA/C24/Cpx (-), e PVA/C24/Tb (-).

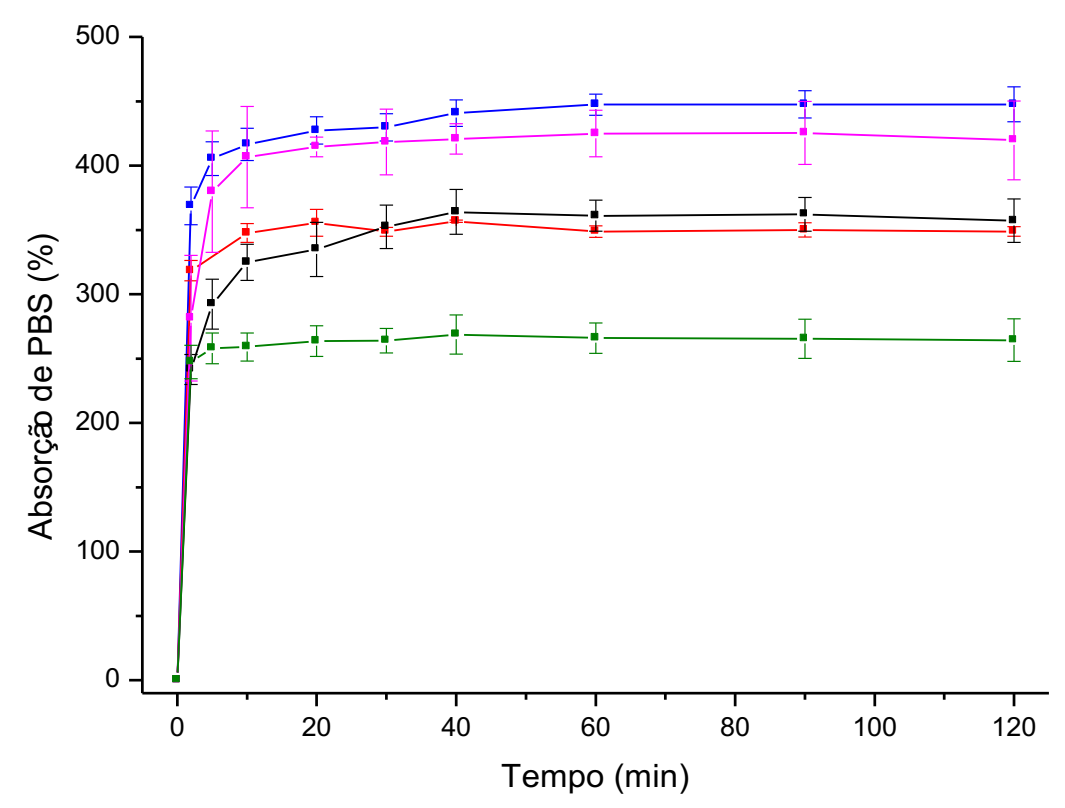

$\mathrm{Na}$ Tabela 9 se comparam os valores de conteúdo de água das membranas com o conteúdo de água da córnea (LIU et al., 2014), os escudos de colágeno (WEISSMAN; LEE, 1988) e a lente de contato Biofinity ${ }^{\circledR}$ (RAD; MOHAJERI, 2016). Os resultados sustentam o fato de que as membranas contendo PVA seriam mais indicadas do que as membranas de C24 para serem aplicadas na superfície da córnea, uma vez que, um alto conteúdo de água favorece a permeabilidade ao oxigênio do material e o conforto para o paciente ( $\mathrm{SHI}$ et al., 2013). Por outro lado, a proximidade entre os conteúdos de água destas membranas 
e o conteúdo de água da córnea, pode indicar também que estes materiais podem ser mais confortáveis e permeáveis ao oxigênio do que os escudos de colágeno e as lentes de contato comerciais, uma vez que, em hidrogéis (como o colágeno e o PVA) a água é o meio de transporte para o oxigênio (EFRON, 2018).

Tabela 9 - Conteúdo de água das membranas, a córnea, escudos de colágeno e
\begin{tabular}{lc}
\multicolumn{1}{c}{ Sistema } & Conteúdo de água (\%) \\
\hline macia Biofinity ${ }^{\circledR}$ & $72,5 \pm 1,3$ \\
PVA/C24 & $77,3 \pm 0,3$ \\
PVA/C24/Cpx & $78,3 \pm 0,9$ \\
PVA/C24/Tb & $81,3 \pm 0,5$ \\
PVA & $80,7 \pm 1,2$ \\
Córnea & $78,0 \pm 3,0$ \\
Escudos de colágeno & $63,2 \pm 1,5$ \\
Lente de contato Biofinity & $46,6 \pm 1,3$ \\
\hline
\end{tabular}

\subsection{5. Ângulo de contato $(\Phi)$}

A molhabilidade é um fenômeno de superfície relacionado à interação entre um liquido e uma superfície sólida quando colocados em contato. Esta propriedade é comumente determinada a partir da medição do ângulo de contato (GUZMAN-ARANGUEZ; COLLIGRIS; PINTOR, 2013). Quando o líquido é água, geralmente se afirma que a superfície é hidrofílica ou de alta molhabilidade se $\circ \Phi$ for menor a $90^{\circ}$ e que é hidrofóbica ou de baixa molhabilidade se o $\Phi$ for maior a $90^{\circ}$. De acordo com essa convenção, todas as membranas obtidas neste estudo têm superfícies hidrofílicas (Figura 27).

A PVA foi a membrana com o menor $\Phi$ como era de se esperar, devido ao alto número de grupos hidrofílicos na sua superfície (JIANG et al., 2014). Devido a isto, na superfície hidrofílica do PVA se forma uma fina camada de água, que explica a baixa tendência deste polímero a aderir proteínas, lipídeos e microrganismos (FALATH; SABIR; JACOB, 2016). Mas a alta hidrofilicidade também 
é responsável pela fragilidade do PVA puro e geralmente limita a sua aplicação (DU et al., 2019).

Figura 27 - Ângulos de contato para água nas membranas de A - PVA, B - C24, C - PVA/C24 e D - PVA/C24/Cpx, E - PVA/C24/Tb.

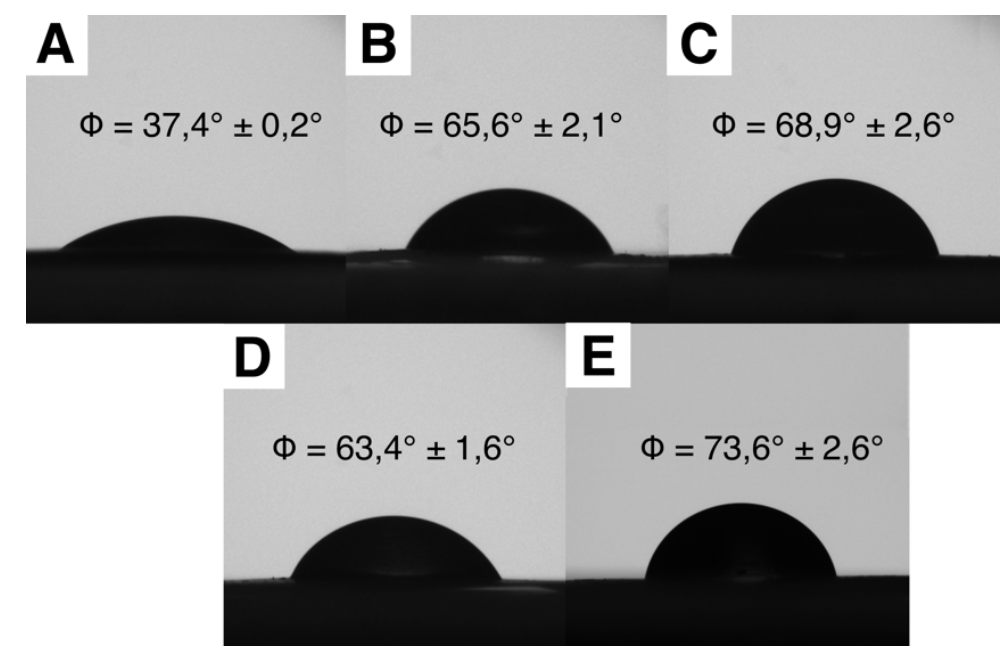

A hidrofilicidade do PVA foi reduzida por mistura com o colágeno aniônico como foi confirmado pelos maiores valores de $\Phi$ das membranas (Figura 27). Este comportamento já tinha sido observado por (SIONKOWSKA et al., 2009) em blendas de PVA e colágeno nativo. Uma possível explicação para isto, é que a presença de fibrilas de colágeno aniônico dispersas na superfície das blendas (item 5.6.1) reduz a área superficial ocupada pelo PVA, diminuindo consequentemente o número de grupos hidrofílicos para interagir com a água na superfície. Como resultado dessa hidrofilicidade reduzida, as membranas contendo colágeno se deformam menos em meio aquoso em relação às membranas de PVA, sendo esta estabilidade de forma uma característica necessária para a aplicação destes materiais na superfície da córnea.

Contudo, as membranas de PVA/colágeno seguem sendo hidrofilicas. E esta hidrofilicidade influi no controle da liberação dos antibióticos e favoreceria o contato com a mucosa ocular, que também é hidrofílica (JAIN et al., 2011; GAVARA; COMPAÑ, 2017). Uma situação contraria se tem em lentes de contato de silicone, onde a hidrofobicidade do material gera pouca compatibilidade com a córnea, favorece a adesão de lipídeos na sua superfície e pode reduzir a mobilidade do dispositivo, com consequente desconforto para o paciente (GAVARA; COMPAÑ, 2017). 


\subsubsection{Transmissão do vapor de água}

Além da correta oxigenação e proteção, o sucesso na reepitelização da córnea requer também da correta umidificação da úlcera (JACOBS; JOHNS; LE, 2013). Nesse sentido o tratamento da úlcera ocular depende da integridade do fluído pré-corneal, que por sua vez vai depender da transmissão de vapor de água através do material usado para cobrir e tratar a ferida.

A permeabilidade ao vapor de água (PV) das membranas de PVA e colágeno aniônico foi determinada (Tabela 10). Similar ao que acontece nas lentes de contato, a transmissão de vapor de água através destas membranas é um processo bidirecional, no qual a água difunde desde o fluído pré-corneal para a superfície anterior da membrana, onde evapora pelo contato com o ar, e ao mesmo tempo a água difunde da superfície anterior da membrana para o fluído pré-corneal por diferença osmótica. O primeiro evento de difusão, conhecido como perevaporação pode ser indesejável porque levaria à desidratação do material, o que pode causar sua adesão ao epitélio e como consequência gerar desconforto para o paciente. $O$ material também poderia retorcer por ressecamento, ocasionando a expulsão da membrana. O segundo evento de difusão é muito desejável porque contribui a manter a umidificação, a eliminação de resíduos e detritos e o transporte de nutrientes para o epitélio, e portanto favoreceria a regeneração tecidual (GAVARA; COMPAÑ, 2017).

Tabela 10 - Valores de PV e TPV para as membranas

\begin{tabular}{lcc}
\hline Membrana & $\mathbf{P V ~}\left(\mathbf{1 0}^{-10} \mathbf{g ~ m}^{-1} \mathbf{s}^{-1} \mathbf{P a}^{-1}\right)$ & TPV $\left(\mathbf{1 0}^{-3} \mathbf{~ g ~ m}^{-\mathbf{2}} \mathbf{s}^{-1}\right)$ \\
\hline C24 & $1,94 \pm 0,03$ & $20,1 \pm 0,4$ \\
PVA/C24 & $1,59 \pm 0,09$ & $7,8 \pm 0,5$ \\
PVA/C24/Cpx & $1,49 \pm 0,08$ & $7,9 \pm 0,4$ \\
PVA/C24/Tb & $1,15 \pm 0,05$ & $7,5 \pm 0,4$ \\
PVA & $1,09 \pm 0,13$ & $6,3 \pm 0,2$ \\
\hline
\end{tabular}

De acordo com a Tabela 10, as membranas de PVA tiveram a menor TPV e PV em relação aos sistemas testados, o que provavelmente foi devido à alta hidrofilicidade deste polímero. A afinidade entre o grande número de grupos hidroxila 
do PVA e as moléculas de água pode reduzir a mobilidade destas pequenas moléculas através da matriz polimérica, comparado ao que aconteceria em polímeros menos hidrofílicos como o colágeno.

Por outro lado, para as membranas de PVA/colágeno os valores de TPV e PV foram intermediários aos valores de TPV e PV dos polímeros puros. Isto provavelmente porque, dada a não miscibilidade dos polímeros, a TPV e a PV das blendas corresponderiam ao valor médio da difusão de vapor de água através de todos os domínios poliméricos distribuídos através da matriz polimérica. Além disso, os valores próximos de TPV para as blendas, indicam que a velocidade de difusão de vapor de água através da matriz de PVA/C24 não varia significativamente $(p>0.05)$ após incorporação dos antibióticos, e as diferenças na PV são devidas às variações na espessura das membranas.

Apesar de ser um fator importante na regeneração da córnea, a PV das lentes de contato e escudos de colágeno tem sido pouco estudada. Gavara e Conpañ (2017) determinaram a TPV e a PV de diversas lentes de contato de silicone hidrogel (LCSiH) e lentes de contato de hidrogel convencionais ( $\mathrm{LCH}$ ) a diferentes gradientes de umidade. Os autores observaram que devido ao maior conteúdo de água dos $\mathrm{LCH}$, as suas $\mathrm{PV}$ foram maiores do que as PV das $\mathrm{LCSiH}$, um comportamento que não foi observado para as membranas de PVA/colágeno aniônico se levar-se em conta que as membranas de PVA tiveram um maior conteúdo de água comparadas às outras membranas. Além disso, os autores relataram que os valores de TPV das lentes de contato variaram entre $27,5 \times 10^{-3} \mathrm{e}$ $44,7 \times 10^{-3} \cdot \mathrm{g} \mathrm{m}^{-2} \mathrm{~s}^{-1}$, os quais são de 3,5 a 5,8 vezes maiores que os valores de TPV das membranas de PVA/colágeno aniônico (Tabela 10). Devido a isto, as membranas de PVA/colágeno aniônico têm uma menor tendência a per-evaporação em relação às lentes de contato, e portanto, seriam mais indicadas para o tratamento de úlceras oculares.

\subsubsection{Propriedades mecânicas}

A durabilidade e a estabilidade durante o manuseio e durante a aplicação dos materiais desenvolvidos foram avaliadas usando ensaios de tração. Esta propriedade mecânica é importante para evitar deformações dos filmes durante o manuseio e aplicação das membranas, prevenindo rupturas, e desconforto para o paciente durante o movimento das pálpebras e deslocamentos do globo ocular 
(TRANOUDIS; EFRON, 2004). O comportamento mecânico sob tração das membranas é apresentado na Figura 28.

Figura 28 - Gráficos de A - Módulo de elasticidade, B - tensão de ruptura e C - deformação na ruptura das membranas secas.

A

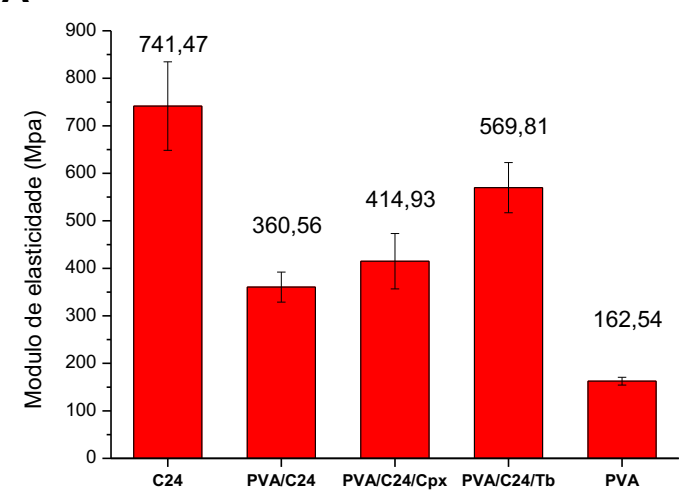

B

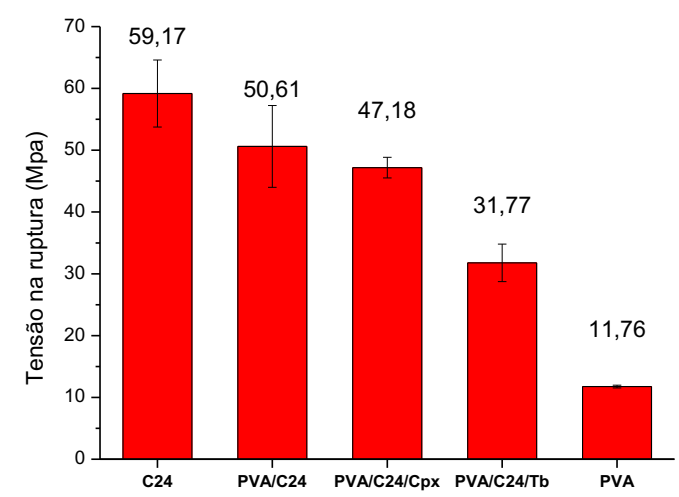

C

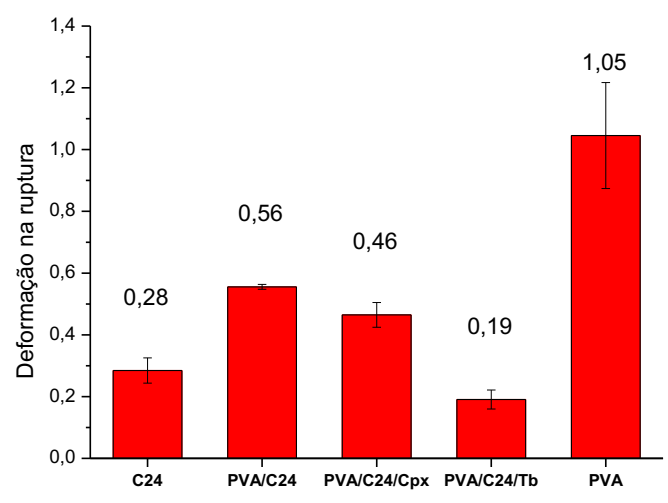

Os maiores valores de resistência na ruptura e o módulo de elasticidade foram registrados para as membranas de C24, o que indica sua maior resistência e rigidez em relação às outras membranas. Essa rigidez pode ser justificada pelo alto conteúdo de fibras presentes no material e a pequena mobilidade dessas fibras nas membranas. Por outro lado, as membranas de PVA tiveram a maior deformação na ruptura e a menor tensão de ruptura comparadas aos outros materiais, como resultado da alta flexibilidade do PVA puro.

No caso das blendas, com exceção da deformação de ruptura para a membrana de PVA/C24/Tb, todas as propriedades mecânicas tiveram valores intermediários (e estatisticamente diferentes, $p<0,05$ ) aos valores obtidos para as membranas de PVA e C24, indicando a compatibilidade mecânica entre os dois polímeros. Isto também significa que, as blendas foram menos rígidas e mais 
flexíveis, quando comparadas com as membranas de C24 e, portanto são mais resistentes ao estresse mecânico associado ao armazenamento e manuseio.

A compatibilidade mecânica entre PVA e colágeno nativo já tinha sido comentada por Sarti e Scandola (1995) ao estudar a miscibilidade das blendas por análise dinâmico-mecânica. Nesse estudo, foi ressaltado que embora os polímeros não sejam miscíveis na faixa de composições de colágeno testadas (30 a 70\%), cada componente da blenda contribui de forma aditiva para o valor do módulo de armazenamento. Segundo os autores, este comportamento mecânico estaria associado provavelmente à disseminação do domínio de colágeno através da matriz de PVA, característica que foi observada para as membranas de PVA/colágeno aniônico usando MEV e AFM (items 5.6.1 e 5.6.2).

Por outro lado, a menor deformação de ruptura e a maior rigidez das membranas de PVA/C24/Tb comparado às demais blendas podem ser explicadas pela reorganização das moléculas poliméricas como consequência do intumescimento e posterior secagem da blenda durante a incorporação de tobramicina (aspecto que foi comentado previamente na avaliação morfológica destas membranas no item 5.6.1).

As membranas de $\mathrm{PVA} / \mathrm{C} 24 / \mathrm{Cpx}$ foram 5,5 vezes mais resistentes à ruptura do que as blendas de PVA/gelatina contendo ciprofloxacina obtidas por Jain et al. (2011). Contudo a deformação de ruptura destas últimas blendas foi aproximadamente 7,5 vezes superior. $O$ fato de que as blendas de PVA/gelatina sejam mais flexíveis do que as de PVA/C24/Cpx é devido à maior liberdade que as cadeias polipeptídicas da gelatina têm para se movimentar uma sob a outra, ao contrário do que acontece com o colágeno devido à estrutura de tripla hélice desta proteína. Além disso, a flexibilidade na blenda de PVA/gelatina é favorecida pela miscibilidade parcial entre os polímeros (MENDIETA-TABOADA et al., 2008). Contudo, a maior resistência na ruptura e a menor deformação de ruptura das membranas de PVA/C24/Cpx indicam que estes sistemas têm menor tendência à deformação não elástica do que as blendas de PVA/gelatina, e portanto, maior estabilidade de forma ante a exigência mecânica durante a inserção do dispositivo ou durante a sua aplicação (devido principalmente ao movimento globo-palpebral do olho) (TRANOUDIS; EFRON, 2004).

Para avaliar as propriedades mecânicas dos materiais durante a aplicação, as membranas de PVA/C24/Cpx e PVA/C24/Tb intumescidas foram 
submetidas ao teste de tração (Figura 29). Como era esperado, o módulo de elasticidade e a tensão de ruptura foram menores em estado intumescido devido ao efeito plastificante da água. A tendência geral de cada propriedade em estado seco e hidratado foram similares, isto é, as membranas de PVA/C24/Cpx foram menos rígidas e com maior tensão de ruptura e deformação do que as membranas de PVA/C24/Tb.

Figura 29 - Módulo de elasticidade $(\square)$, a tensão de ruptura $(\square)$ e a deformação na ruptura $(\square)$ das membranas de PVA/C24/Cpx e PVA/C24/Tb intumescidas.

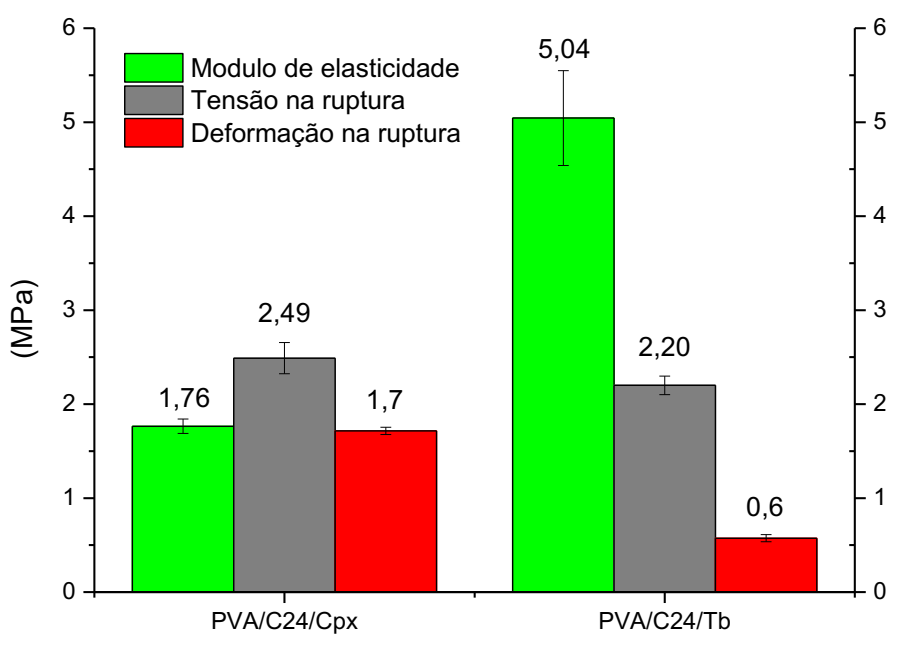

As propriedades mecânicas destas membranas foram comparadas com as propriedades mecânicas das lentes de contato macias fabricadas com 2hidroxietilmetacrilato (HEMA), HEMA/vinilpirrolidona, vinilpirrolidona/metilmetacrilato e (HEMA)/ácido metacrílico, determinadas por Tranoudis e Efron (2004). De forma geral, a tensão de ruptura de todas essas lentes de contato variou entre 0,2 e 0,4 $\mathrm{MPa}$, a deformação de ruptura variou entre 0,52 e 0,82 e o módulo de elasticidade entre 0,4 a 0,7 MPa. O fato de que as membranas de PVA/C24/Tb e PVA/C24/Cpx tenham maior tensão de ruptura, uma deformação de ruptura similar ou superior e módulo de elasticidade superior às lentes de contato macias indica que, estas membranas são mais fortes e tenazes, e portanto, tendem a conservar mais suas dimensões durante o uso.

\subsubsection{Transmissão de luz visível}

A transparência de um material projetado para interagir com a córnea é uma propriedade muito importante para avaliar sua aplicação. Isto, porque qualquer 
redução na capacidade visual associada à presença do material na superfície da córnea gera desconforto para o paciente. Este desconforto é maior se o paciente requer tratamento em ambos olhos simultaneamente.

A transmissão de luz das membranas contendo colágeno aniônico foi maior com o aumento do comprimento de onda (Figura 30), similar a como acontece na córnea. Mas a transmissão de luz através da córnea é superior à destes materiais ( $80 \%$ a $380 \mathrm{~nm}$ e mais de $90 \%$ depois de $500 \mathrm{~nm}$ ) (MEEK; KNUPP, 2015). Isto é devido a que a córnea é um material com uma estrutura altamente organizada, onde as fibrilas de colágeno são de diâmetro uniforme e perfeitamente espaçadas para reduzir ao mínimo a dispersão de luz (DUAN; SHEARDOWN, 2006). Mas nas membranas de C24, PVA/C24, PVA/C24/Tb e PVA/C24/Cpx, cujo colágeno foi obtido por hidrólise alcalina do tendão bovino, não há uma disposição tão uniforme das fibrilas, o que explicaria sua menor transparência com relação à córnea.

Figura 30 - Transmissão de luz na faixa visível do espectro luminoso (400-800nm) das membranas de PVA (一), C24 (一), PVA/C24 (—), PVA/C24/Cpx (一), e PVA/C24/Tb (一).

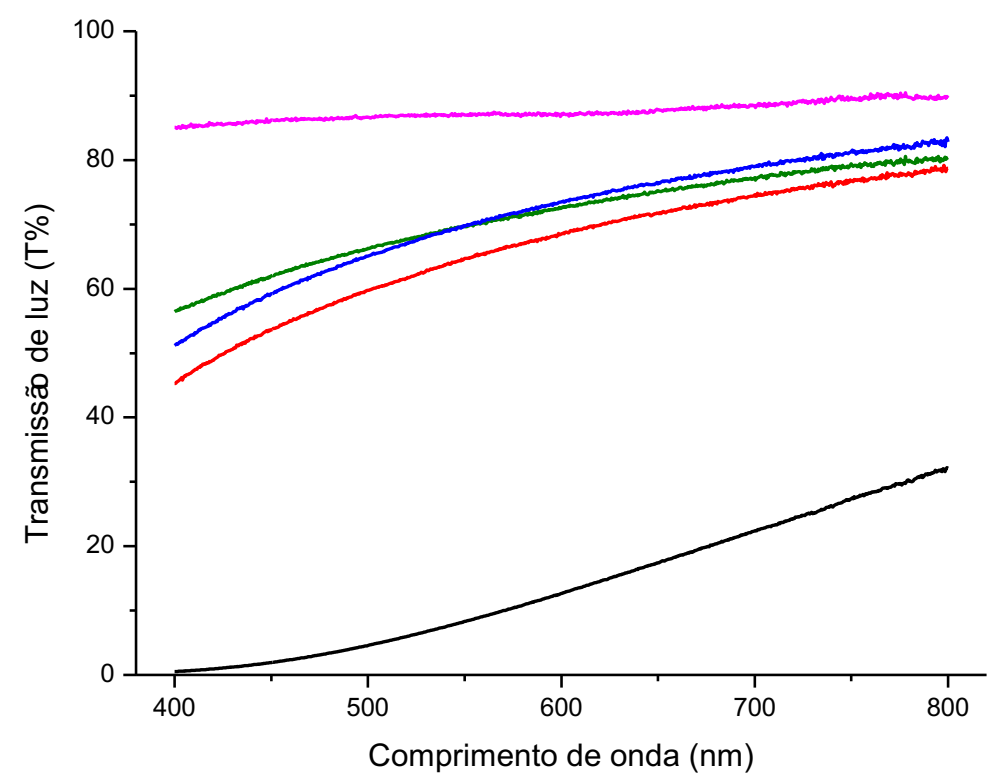

Com base na Figura 30, pode-se afirmar que as membranas de PVA foram os sistemas com maior transparência, como era esperado. Mas a transparência do PVA influiu pouco nas outras membranas, como pode verificar-se pela semelhança dos valores das transmissões de luz entre as membranas de C24, PVA/C24 e PVA/C24/Tb e a baixa transmissão de luz da membrana de $\mathrm{PVA} / \mathrm{C} 24 / \mathrm{Cpx}$. 
A imiscibilidade entre os polímeros e a distribuição aleatória das fibrilas de colágeno podem ter sido os fatores responsáveis pelo não aumento da transmissão de luz nas membranas de PVA/C24 e PVA/C24/Tb com relação às membranas de C24. Contudo, a transmissão de luz destas membranas foi superior comparada com a transmissão de luz dos escudos de colágeno desenvolvidos por Agban et al. (2016) para a liberação de cloridrato de pilocarpina.

No caso das membranas de PVA/C24/Cpx a presença de ciprofloxacina favoreceu a separação de fases no material, resultando em opacidade, como foi discutido no item 5.6.1. Isto é claramente uma desvantagem para estes sistemas, mas não uma limitante para sua aplicação (NGUYEN et al., 2012).

\subsubsection{Solubilidade do material}

A dissolução do material em meio aquoso é um fator importante para a determinação da viabilidade das membranas, em especial porque estes dispositivos foram fabricados a partir de componentes hidrofílicos. Uma excessiva dissolução do material pode levar à fragmentação prematura das membranas, a uma redução significativa do seu volume ou perda do seu formato. Claramente, qualquer uma destas situações reduziria a eficácia do dispositivo, seja por extrusão do material, por efeito mecânico das pálpebras ou por desconforto do paciente.

A dissolução das membranas foi determinada a $48 \mathrm{~h}$ de imersão em PBS (Tabela 11) que é o período de liberação dos antibióticos (estabelecido no item 5.3).

\begin{tabular}{|c|c|}
\hline Membrana & Solubilidade (\%) \\
\hline $\mathrm{C} 24$ & 0 \\
\hline PVA/C24 & $15,1 \pm 0,9$ \\
\hline PVA/C24/Cpx & $22,1 \pm 1,1$ \\
\hline PVA/C24/Tb & $3,5 \pm 0,3$ \\
\hline PVA & $25,0 \pm 2,5$ \\
\hline
\end{tabular}

Uma vez que a solubilidade do colágeno aniônico puro não foi observada, se intui que a perda de massa das membranas foi devida principalmente a dois fenômenos: a dissolução de PVA devido à sua fase amorfa e a liberação dos antibióticos. Tomando como exemplo a PVA/C24, o 75\% da sua massa corresponde a PVA e o $25 \%$ desse PVA é solúvel segundo a Tabela 11 , então a perda de massa 
teórica da blenda por solubilização seria aproximadamente de $18 \%(0,75 \times 0,25=$ 0,18). Usando um cálculo similar (Apêndice 4), e considerando a liberação dos antibióticos, se encontra que a perda de massa teórica para as PVA/C24/Cpx e as PVA/C24/Tb seria de $22,5 \%$ e 3,7\% respectivamente, que são valores próximos aos resultados experimentais (Tabela 11). O fato de que o colágeno não tenha dissolvido no meio aquoso, pode indicar que este polímero ajuda a conservar a estrutura tridimensional da membrana, e manter o formato dos materiais após a liberação dos antibióticos ter ocorrido (como será discutido no próximo item).

A solubilidade do PVA depende da sua massa molar e seu grau de hidrólise. Quanto maior a massa molar e o grau de hidrólise, este poliálcool tende a ser mais cristalino, diminuindo assim sua solubilidade em água. Devido ao PVA usado neste estudo ser de alta massa molar (70000 - 100000) e alto grau de hidrólise (> 95\%), as membranas desenvolvidas com este polímero têm uma solubilidade baixa em PBS, apesar de não terem sido reticuladas.

A solubilidade de todas as membranas foi inferior à solubilidade dos insertos oculares de PVA (35-38\%) desenvolvidos por Balasubramaniam et al. (2006).

\subsubsection{Uniformidade e estabilidade de forma das membranas}

As membranas foram avaliadas em quanto a sua uniformidade e à capacidade para conservar seu formato após a liberação dos antibióticos. A uniformidade das membranas é importante para garantir a sua reprodutibilidade na liberação dos antibióticos e a estabilidade de forma é útil para saber se o dispositivo pode ser expulso da superfície ocular devido à deformação ou à fragmentação do material durante a aplicação.

A variação pouco significativa no diâmetro e na espessura entre os discos de PVA/C24/Cpx e PVA/C24/Tb (Tabela 12) foi indicativo de que a metodologia usada para preparar as membranas e a forma de serem cortadas foram adequadas para se obter dispositivos de dimensões uniformes e estáveis ao intumescimento. As membranas não fragmentaram e a sua deformação por intumescimento foi maior na espessura do que no diâmetro, dando como resultado materiais com pouca tendência a se retorcer, o que reduz o risco de serem expulsas durante sua aplicação. 
Tabela 12 - Massa e dimensões das membranas de PVA/C24/Cpx e PVA/C24/Tb em formato de discos de $0,5 \mathrm{~cm}^{2}$

\begin{tabular}{ccccccc}
\hline \multirow{2}{*}{ Membrana } & \multicolumn{3}{c}{ Discos secos } & \multicolumn{3}{c}{ Discos intumescidos* } \\
\cline { 2 - 7 } & $\begin{array}{c}\text { Massa } \\
(\mathbf{m g})\end{array}$ & $\begin{array}{c}\text { Diâmetro } \\
(\mathbf{m m})\end{array}$ & $\begin{array}{c}\text { Espessura } \\
(\mathbf{m m})\end{array}$ & $\begin{array}{c}\text { Massa } \\
(\mathbf{m g})\end{array}$ & $\begin{array}{c}\text { Diâametro } \\
(\mathbf{m m})\end{array}$ & $\begin{array}{c}\text { Espessura } \\
(\mathbf{m m})\end{array}$ \\
\hline PVA/C24/Cpx & $3,1 \pm 0,1$ & $7,9 \pm 0,1$ & $0,06 \pm 0,01$ & $10,0 \pm 0,4$ & $8,5 \pm 0,2$ & $0,15 \pm 0,01$ \\
PVA/C24/Tb & $2,0 \pm 0,1$ & $7,8 \pm 0,1$ & $0,05 \pm 0,01$ & $6,6 \pm 0,6$ & $8,1 \pm 0,1$ & $0,12 \pm 0,01$ \\
\hline \multicolumn{2}{c}{${ }^{*}$ Durante $48 \mathrm{~h} \mathrm{em} \mathrm{PBS} \mathrm{a} 37^{\circ} \mathrm{C}$} & & & &
\end{tabular}

Na Figura 31 se observa que os discos de PVA/C24/Tb e PVA/C24/Cpx tiveram uma deformação por intumescimento similar à dos discos C24 e PVA/C24. Em contraste, a deformação do disco de PVA aconteceu com um considerável aumento do diâmetro. Como resultado, o disco de PVA tende a se dobrar facilmente, dificultando seu manuseio. Disto se pode concluir que o colágeno exerce o controle da estrutura tridimensional das membranas de PVA/colágeno aniônico durante o intumescimento do material.

Figura 31 - Membranas de A - C24, B - PVA, C - PVA/C24, D - PVA/C24/Tb e E - PVA/C24/Cpx em formato de discos de $0,5 \mathrm{~cm}^{2}$.

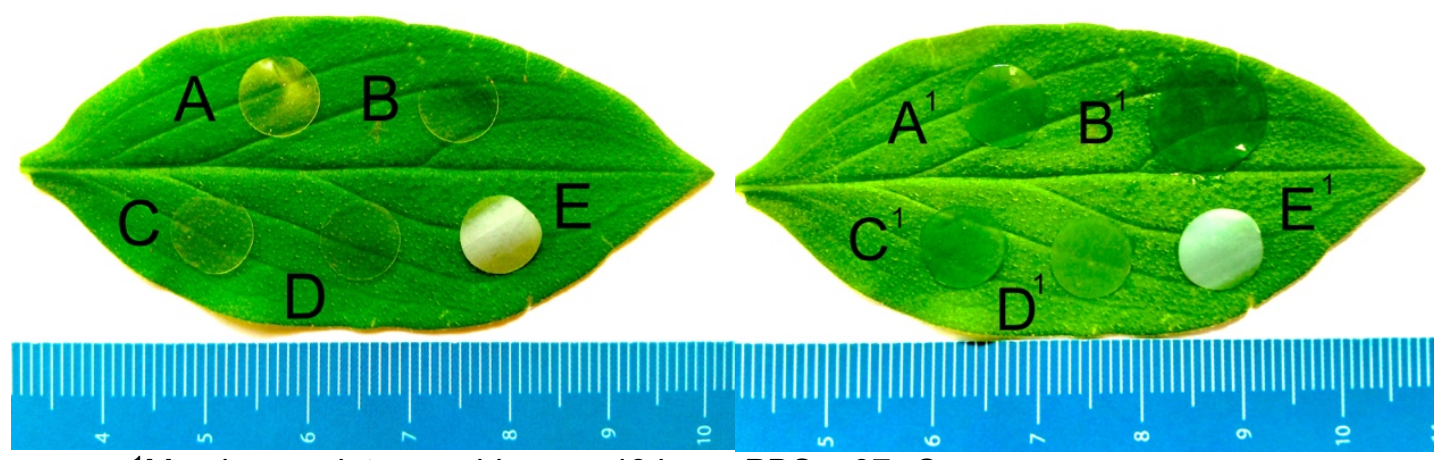

${ }^{1}$ Membranas intumescidas por $48 \mathrm{~h}$ em PBS a $37^{\circ} \mathrm{C}$.

\subsubsection{1. $\mathrm{pH}$ das membranas}

$\mathrm{O} \mathrm{pH}$ da água na que foram submergidas as membranas de PVA/C24/Tb e PVA/C24/Cpx variou entre 6 e 7. De acordo com Agban et al. (2016), devido à capacidade tamponante do fluido pré-corneal, as formulações com um pH entre $5 \mathrm{e}$ 8 podem ser bem toleradas. Então é provável que as membranas de PVA/colágeno aniônico não causem irritação na superfície ocular dos pacientes. 


\subsection{Atividade antimicrobiana (in vitro)}

\subsubsection{Concentração inibitória mínima (CIM) dos antibióticos}

A CIM obtida para as linhagens testadas para a ciprofloxacina e tobramicina encontram-se nas Tabelas 13 e 14, respectivamente.

Tabela 13 - Concentração Inibitória Mínima para Ciprofloxacina

\begin{tabular}{|c|c|c|}
\hline Linhagens bacterianas & $\begin{array}{l}\text { CIM obtida } \\
\left(\mu \mathrm{g} \mathrm{mL} \mathrm{m}^{-1}\right)\end{array}$ & $\begin{array}{l}\text { CIM preconizada pelo } \\
\text { CLSI }(2017)\left(\mu \mathrm{gL}^{-1}\right)\end{array}$ \\
\hline $\begin{array}{l}\text { Staphylococcus aureus } \\
\text { ATCC } 29213\end{array}$ & 0,5 & $0,12-0,5$ \\
\hline $\begin{array}{l}\text { Pseudomonas aeruginosa } \\
\text { ATCC } 27853\end{array}$ & 0,25 & $0,25-1,0$ \\
\hline $\begin{array}{l}\text { Escherichia coli } \\
\text { ATCC } 25922\end{array}$ & 0,008 & $0,004-0,016$ \\
\hline
\end{tabular}

Tabela 14 - Concentração Inibitória Mínima para Tobramicina

\begin{tabular}{lcc}
\hline \multicolumn{1}{c}{ Linhagens bacterianas } & $\begin{array}{c}\text { CIM obtida } \\
\left(\boldsymbol{\mu g} \mathbf{~ m L}^{-1}\right)\end{array}$ & $\begin{array}{c}\text { CIM preconizada pelo } \\
\text { CLSI }(\mathbf{2 0 1 7})\left(\boldsymbol{\mu g} \mathbf{~ m L}^{-1}\right)\end{array}$ \\
\hline $\begin{array}{l}\text { Staphylococcus aureus } \\
\text { ATCC 29213 }\end{array}$ & 0,5 & $0,12-1,0$ \\
$\begin{array}{l}\text { Pseudomonas aeruginosa } \\
\text { ATCC 27853 }\end{array}$ & 0,5 & $0,25-1,0$ \\
$\begin{array}{l}\text { Escherichia coli } \\
\text { ATCC 25922 }\end{array}$ & 1,0 & $0,25-1,0$ \\
\hline
\end{tabular}

Com base nos resultados das liberações in vitro das membranas de PVA/C24/Tb e PVA/C24/Cpx (item 5.3) espera-se que os discos de $0,5 \mathrm{~cm}^{2}$ liberarem aproximadamente 54,6 $\mathrm{\mu g}$ de tobramicina e 137,8 $\mathrm{gg}$ de ciprofloxacina, respectivamente. Tendo em conta que a quantidade de fluido lacrimal que estaria em contato com estes discos durante um período de $48 \mathrm{~h}$ seria aproximadamente $3 \mathrm{~mL}\left(1 \mu \mathrm{L} \mathrm{min}^{-1}\right)$, pode-se prever o potencial das membranas para inibir o crescimento de $S$. aureus, $P$. aeruginosa e $E$. coli pois liberariam quantidades de antibiótico que seriam superiores às CIM de cada microrganismo. Estas estimativas não são decisivas para ser associadas a um efeito terapêutico, pois material liberaria progressivamente o antibiótico e a cada momento sua concentração na superfície ocular seria variável. Por tal motivo, no presente estudo foram empregados dois 
tipos de experimentos para avaliar a atividade antimicrobiana das membranas de PVA/C24/Tb e PVA/C24/Cpx.

\subsubsection{Experimento 1: Time-Kill}

A cinética do tempo de morte ("time-kill") das bactérias $S$. aureus, $P$. aeruginosa e E. coli após exposição à ciprofloxacina, tobramicina e às membranas foi avaliada no período de $48 \mathrm{~h}$ com a determinação do $\log _{10}$ UFC mL-1 nos tempos $0,1,2,4,8,24$ e 48 h (Figura 32).

Figura 32 - Time-kill da bactéria S. aureus ATCC 29213 após exposição A - à ciprofloxacina (-) e à membrana de PVA/C24/Cpx (-) e B - à tobramicina (-) e à membrana de PVA/C24/Tb (-). A exposição às membranas de PVA/C24 (-) promoveu o crescimento bacteriano tanto como o controle positivo (一).
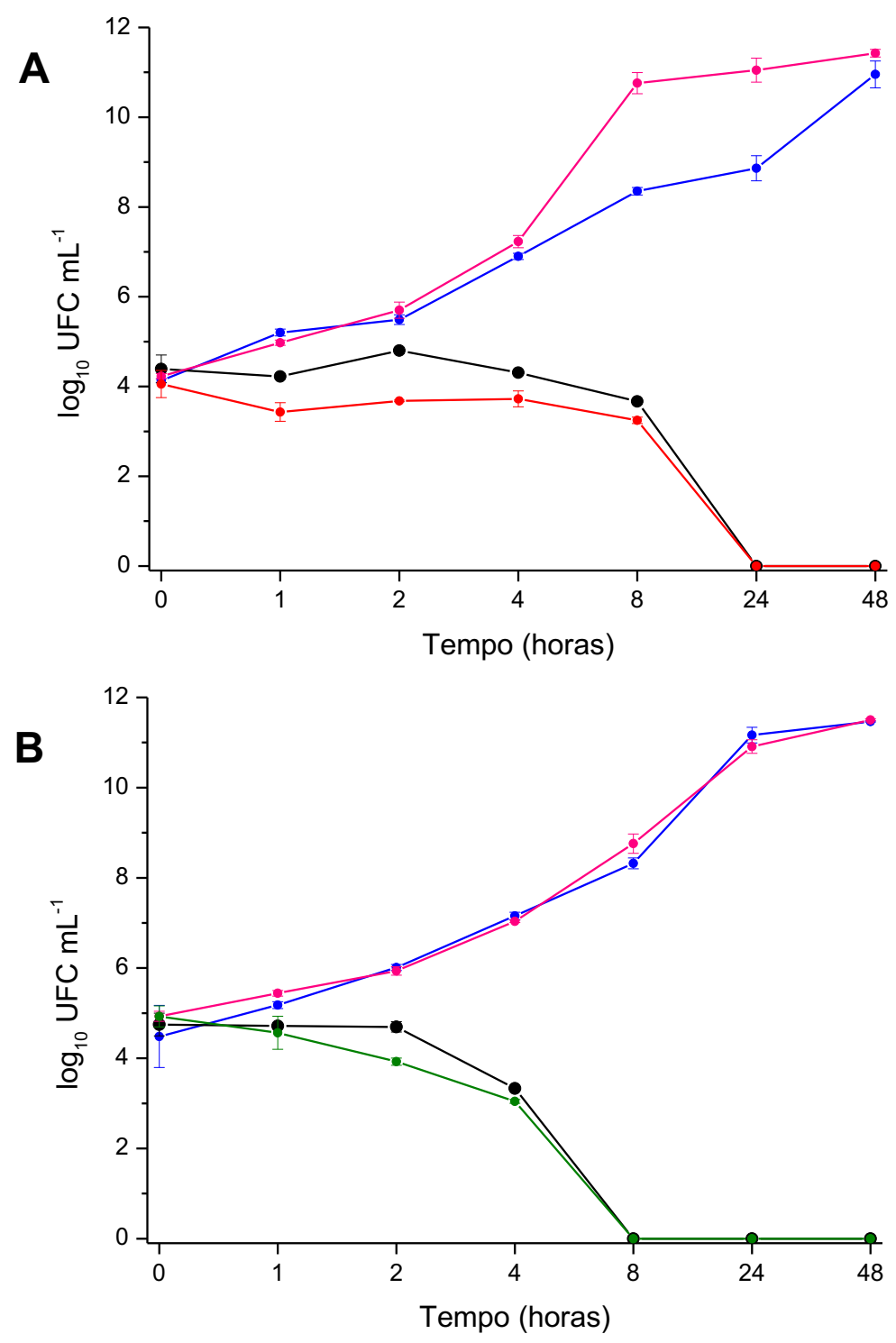
O controle de crescimento das bactérias resultou como esperado, assim como o segundo controle de crescimento contendo as membranas de PVA/C24, mostrando que a matriz polimérica sozinha não apresenta toxicidade para as bactérias (Figuras 32 e 33). Em quanto às amostras contendo ciprofloxacina, tanto para a ciprofloxacina livre $($ a $0,5 \mu \mathrm{g} / \mathrm{ml})$ quanto para a membrana de PVA/C24/Cpx não foi possível observar o crescimento de $S$. aureus após $24 \mathrm{~h}$ de exposição, indicando a morte bacteriana entre o período de 8 e 24 h (Figura 32A).

Figura 33 - Time-kill da bactéria E. coli ATCC 25922 após exposição A - à ciprofloxacina (-) e à membrana de PVA/C24/Cpx (—) e B - à tobramicina (-) e à membrana de PVA/C24/Tb (-). A exposição às membranas de PVA/C24 (-) promoveu o crescimento bacteriano tanto como o controle positivo (-).
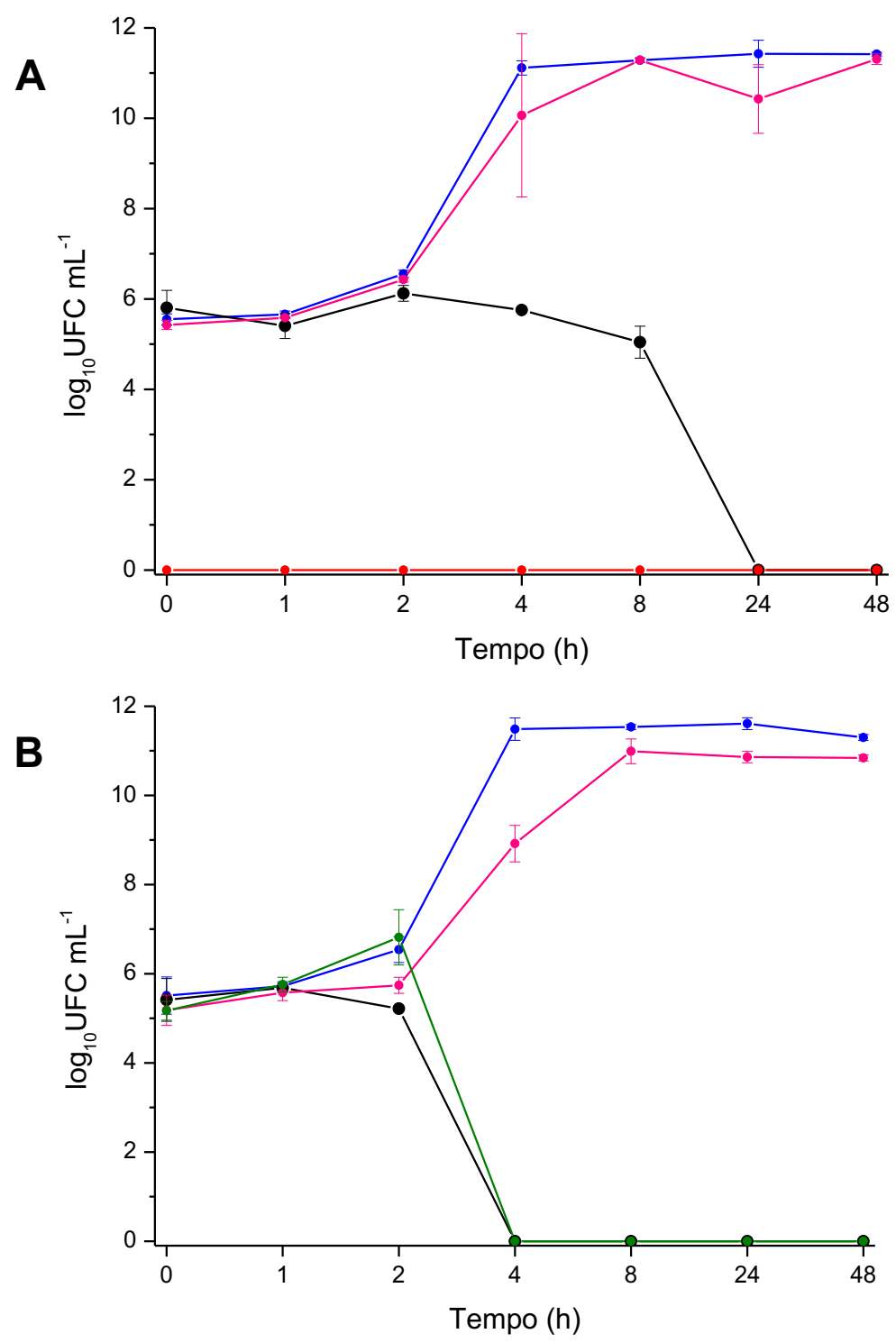
No caso das amostras contendo tobramicina, tanto para a tobramicina livre (a $0,5 \mu \mathrm{g} \mathrm{mL}^{-1}$ ) quanto para a membrana de PVA/C24/Tb não foi possível observar o crescimento bacteriano após $8 \mathrm{~h}$ de exposição, indicando morte bacteriana entre o período de 4 e $8 \mathrm{~h}$ (Figura 32B). Disto se infere que a tobramicina apresentou maior eficiência do que a ciprofloxacina para inibir o crescimento desta linhagem Gram-positiva, o que não necessariamente está relacionado à liberação controlada das membranas, mas sim ao método de ação dos diferentes antibióticos, uma vez que o antibiótico livre apresentou comportamentos similares ao das membranas contendo antibiótico.

No time-kill para E. coli não foi possível observar o crescimento bacteriano desde a primeira hora de exposição às membranas de PVA/C24/Cpx (Figura 33A) e após $24 \mathrm{~h}$ de exposição à ciprofloxacina livre $\left(\right.$ a $\left.0,008 \mu \mathrm{g} \mathrm{m}^{-1}\right)$ indicando no segundo caso, a morte bacteriana entre o período de 2 e $4 \mathrm{~h}$ (Figura 33B). E possível que a morte bacteriana nos poços contendo membranas de PVA/C24/Cpx tenha acontecido de maneira imediata devido à alta concentração de ciprofloxacina que estes sistemas liberaram no meio, em relação ao CIM para esta linhagem. No caso das amostras contendo tobramicina, tanto para a tobramicina livre (a 1,0 $\mu \mathrm{g}$ $\mathrm{mL}^{-1}$ ) quanto para a membrana de $\mathrm{PVA} / \mathrm{C} 24 / \mathrm{Tb}$ não foi possível observar o crescimento de E. coli após $4 \mathrm{~h}$ de exposição (Figura 33B), indicando morte bacteriana entre o período de 2 e $4 \mathrm{~h}$ (Figura 33B). Esta atividade bactericida foi mais rápida do que a observada para $S$. aureus como era esperado, pois a tobramicina é especialmente indicada para tratar infeções causadas por Gramnegativas (SUEKE et al., 2013).

Por último, foi feito o time-kill usando Pseudomonas aeruginosa, porém não foi possível a quantificação das UFC.

\subsubsection{Experimento 2}

Neste experimento foi determinada a ação bactericida dos discos de membranas, após estes dispositivos terem liberado o antibiótico por 0, 1, 2, 4, 8, 24 e $48 \mathrm{~h}$ em PBS.

Com base nos resultados do experimento 1, a contagem das células viáveis foi feita após as 24 horas de incubação. Tanto para S. aureus como para $E$. coli, não foi possível observar crescimento bacteriano em nenhuma das amostras contendo as membranas de PVA/C24/Cpx, indicando que após $48 \mathrm{~h}$ de liberação 
estes dispositivos ainda têm ação bactericida contra as duas bactérias (Figura 34). Por outro lado, o controle positivo obteve crescimento de $10^{11}$ UFC $\mathrm{mL}^{-1}$ (log UFC $\mathrm{mL}^{-1}$ de $\left.11,50 \pm 0,06\right)$ para $S$. aureus e $10^{11} \mathrm{UFC} \mathrm{mL}^{-1}\left(\log \mathrm{UFC} \mathrm{mL}^{-1}\right.$ de $\left.11,6 \pm 0,1\right)$ para E. coli. Estes resultados confirmam que as membranas de PVA/C24/Cpx são sistemas de liberação controlada com ação bactericida contra bactérias Grampositivas e Gram-negativas como S. aureus e E. coli.

Figura 34 - Crescimento celular de A - S. aureus e B - E. coli, após incubação de 24 horas com as membranas de PVA/C24/Cpx ( $\square$ ) e PVA/C24/Tb ( $\square$ ) incubadas previamente em PBS pelos tempos indicados.
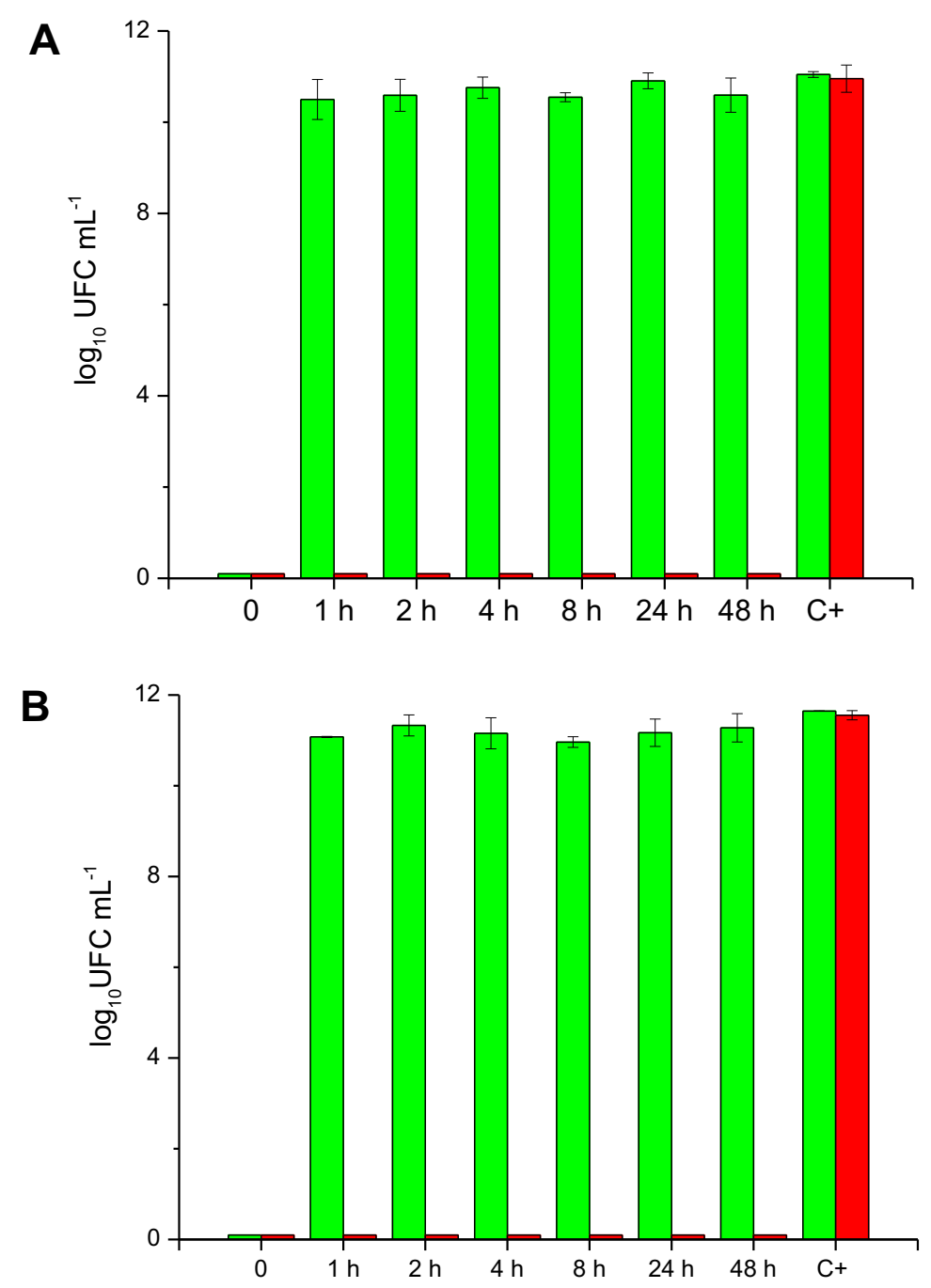

A atividade antimicrobiana das membranas de PVA/C24/Cpx pode ser explicada de acordo aos resultados da sua liberação in vitro (item 5.3). Na Tabela 15 observa-se que a taxa de liberação de ciprofloxacina na superfície ocular para os discos de PVA/C24/Cpx, seria de aproximadamente $1,4 \mu \mathrm{g} / \mathrm{mL}^{-1} \mathrm{~h}$ após $48 \mathrm{~h}$, uma 
concentração que é 2,8 vezes superior à CIM da ciprofloxacina para S. aureus e 175 vezes superior à CIM da ciprofloxacina para E. coli (item 5.6.12.1).

Tabela 15 - Taxa de liberação teórica de um disco de PVA/C24/Cpx de $0,5 \mathrm{~cm}^{2}$ na superfície ocular. Estes valores foram calculados tendo em conta que a taxa de produção de lágrimas é $1 \mu \mathrm{g} \mathrm{mL}^{-1}$

\begin{tabular}{lcccccc}
\hline & \multicolumn{6}{c}{ Tempo de liberação de ciprofloxacina (h) } \\
\cline { 2 - 7 } & $\mathbf{1}$ & $\mathbf{2}$ & $\mathbf{4}$ & $\mathbf{8}$ & $\mathbf{2 4}$ & $\mathbf{4 8}$ \\
\hline $\begin{array}{l}\text { Taxa de liberação de } \\
\text { ciprofloxacina }\left(\mu \mathrm{g} \mathrm{mL} \mathrm{mL}^{-1} \mathrm{~h}\right)\end{array}$ & 1570,0 & 142,9 & 110,2 & 34,7 & 9,8 & 1,4 \\
\hline
\end{tabular}

Por outro lado, na Figura 34 observa-se que no caso das membranas de PVA/C24/Tb somente se verificou morte celular de $S$. aureus e E. coli com o disco sem liberação prévia em PBS $(0 \mathrm{~h})$. Este resultado é condizente com o obtido no time-kill onde não se observou crescimento bacteriano após $24 \mathrm{~h}$ de incubação para este material. Para os discos submergidos em PBS, o crescimento bacteriano foi comparável ao controle positivo, o que indica que a tobramicina liberada por estes sistemas após a primeira hora de exposição ao PBS, já é insuficiente para uma ação bactericida. Este resultado não condiz com a hipótese de que $S$. aureus e $E$. coli poderiam ter influência na degradação do material, com a qual seria possível a liberação da tobramicina retida pela matriz polimérica (item 5.3). Porém, ainda não se descarta a possibilidade de que se dê a liberação da tobramicina in vivo a partir destes materiais.

Por último, a linhagem de Pseudomonas aeruginosa não foi usada no experimento 2, já que não foi possível a quantificação das UFC.

\subsection{Considerações finais}

Alguns aspectos quanto ao uso dos sistemas de liberação controlada de antibióticos desenvolvidos neste trabalho que não foram considerados durante a discussão dos resultados. Por exemplo, que estes sistemas provavelmente sejam efetivos em caso de pequenas úlcerações ( $<3 \mathrm{~mm}$ de diâmetro) como no caso dos escudos de colágeno, já que maiores perfurações geralmente são manejadas cirurgicamente (JHANJl et al., 2011). Por outro lado, além de tratar a infecção associada às úlceras oculares, as membranas podem minimizar o dano mecânico ao epitélio em formação, causado pelo movimento das pálpebras, contribuindo assim 
para acelerar o processo de regeneração da córnea. Além disso, a presença de colágeno nas membranas poderia reduzir a inflamação da córnea, com o qual se evitaria o uso de agentes inflamatórios, os quais podem aumentar o dano na córnea quando são usados como adjuvantes de antibióticos (CALLEGAN; O'CALLAGHAN; HILL, 1994).

Um aspecto importante a destacar é que, de acordo com as Tabelas $4 \mathrm{e}$ 5 , a quantidade de ciprofloxacina e tobramicina incorporada nos discos de $0,5 \mathrm{~cm}^{2}$ é de $143 \mu \mathrm{g}$ e $156 \mu \mathrm{g}$, respectivamente. Uma quantidade que é de 100 a 200 vezes inferior à quantidade total de antibiótico administrado usando colírios comerciais $(0,3 \%)$ e colírios fortificados $(1,4 \%)$ a cada $30 \mathrm{~min}$, durante $48 \mathrm{~h}$. Portanto, estes dispositivos seriam menos propensos a causar toxicidade ocular ou sistêmica comparados aos colírios.

Embora a discussão sobre o uso das membranas foi dirigida ao tratamento das úlceras oculares, estes sistemas também podem ser usados para outros tipos de infecções oculares, como conjuntivite bacteriana ou também para o tratamento pré- e pós-operatório de cirurgias oculares como ceratoplastias e ceratotomias. Além disso, embora o uso das membranas tenha sido dirigido a cães, no futuro poderiam ser usados em outro tipo de pacientes, como por exemplo humanos, tomando as devidas considerações éticas. 


\section{CONCLUSÃO}

Neste trabalho foram desenvolvidas e caracterizadas membranas no sistema PVA/colágeno aniônico. Dentro deste sistema foi observado que as membranas de PVA/C24/Cpx funcionam como sistemas de liberação controlada de ciprofloxacina com atividade bactericida contra $S$. aureus e $E$. coli por um período de $48 \mathrm{~h}$, e comprovou-se que estas membranas têm as propriedades físicas adequadas para ser empregadas no tratamento das úlceras oculares em cães. De fato, estes materiais podem ser considerados alternativas superiores aos colírios, e independentes deles, para o tratamento das ceratites bacterianas.

Também foram desenvolvidas e caracterizadas as membranas de $\mathrm{PVA} / \mathrm{C} 24 / \mathrm{Tb}$, as quais apresentam uma significativa retenção de tobramicina e têm atividade bactericida contra $S$. aureus, mas não atuam como sistemas de liberação controlada in vitro. Porém, estes materiais não deveriam ser descartados, devido às suas propriedades físicas e porque é possível que a liberação controlada de tobramicina aconteça in vivo, estimulada pela degradação enzimática do material.

Por outro lado, as membranas de PVA e colágeno aniônico não foram adequadas para a liberação controlada de cloranfenicol.

É muito provável que os sistemas de liberação selecionados neste estudo não apresentem citotoxicidade ocular nem sistêmica, devido a que não foi necessário o uso de agentes reticulantes para incorporação dos antibióticos, e além disso, estes sistemas contêm quantidades de antibiótico baixas com relação às quantidades administradas usando colírios. 


\section{PERSPECTIVAS PARA TRABALHOS FUTUROS}

- As membranas de PVA/C24/Tb e PVA/C24/Cpx foram esterilizadas e enviadas para o Prof. Dr. Alexandre Lima de Andrade, quem será responsável pela avaliação destes sistemas em quanto a produção de efeitos secundários como irritação e neovascularização da córnea em modelos animais como ratos ou coelhos, para posteriormente decidir se estes materiais são aptos para serem usados em cachorros.

- As membranas de PVA/colágeno aniônico também poderiam ser testadas para a liberação de outro tipo de antibióticos, assim como a liberação de outro tipo de fármacos como antifúngicos, antivirais, anti-inflamatório, imunossupressores, ou anticoagulantes.

- Devido às propriedades físicas das membranas de PVA/Colágeno aniônico, estas membranas ainda poderiam ser avaliadas quanto a sua capacidade para suportar o crescimento de células epiteliais da córnea, visando seu uso como ceratopróteses.

- O uso de nanopartículas ou micropartículas do sistema PVA/colágeno aniônico para a incorporação dos fármacos pode ser uma estratégia efetiva para melhorar os sistemas de liberação desenvolvidos neste trabalho. 


\section{APÊNDICE}

\section{Apêndice 1}

A. Mecanismo de reticulacão do colágeno com glutaraldeído

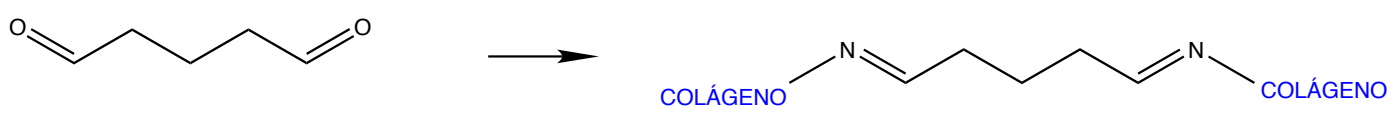

COLÁGENO- $\mathrm{NH}_{2} \quad \mathrm{H}_{2} \mathrm{~N} \longrightarrow$ COLÁGENO

B. mecanismo de ligação covalente da tobramicina ao colágeno usando EDC e NHS.

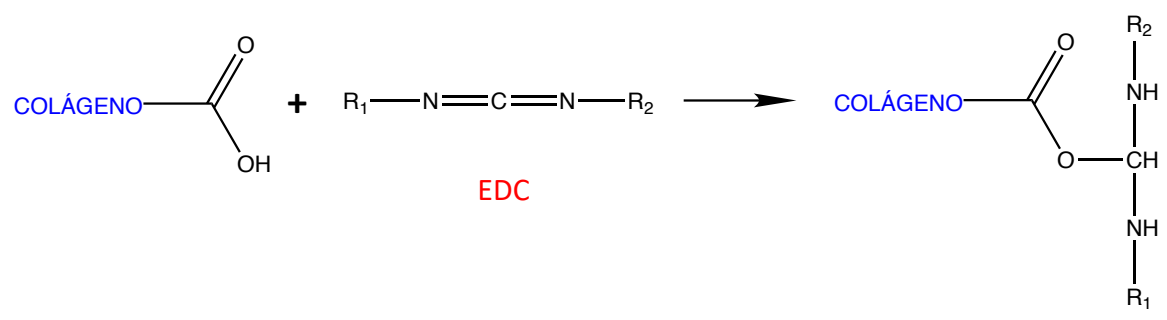

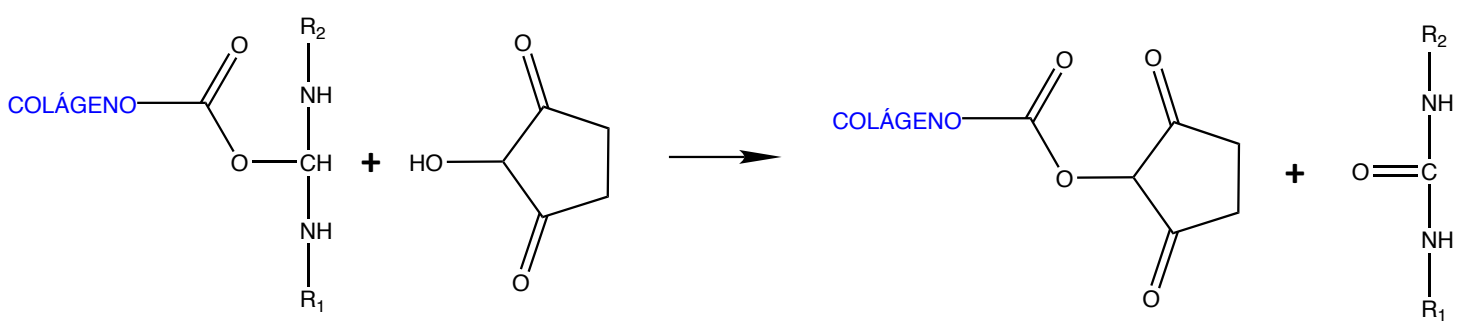

NHS

TOBRAMICINA
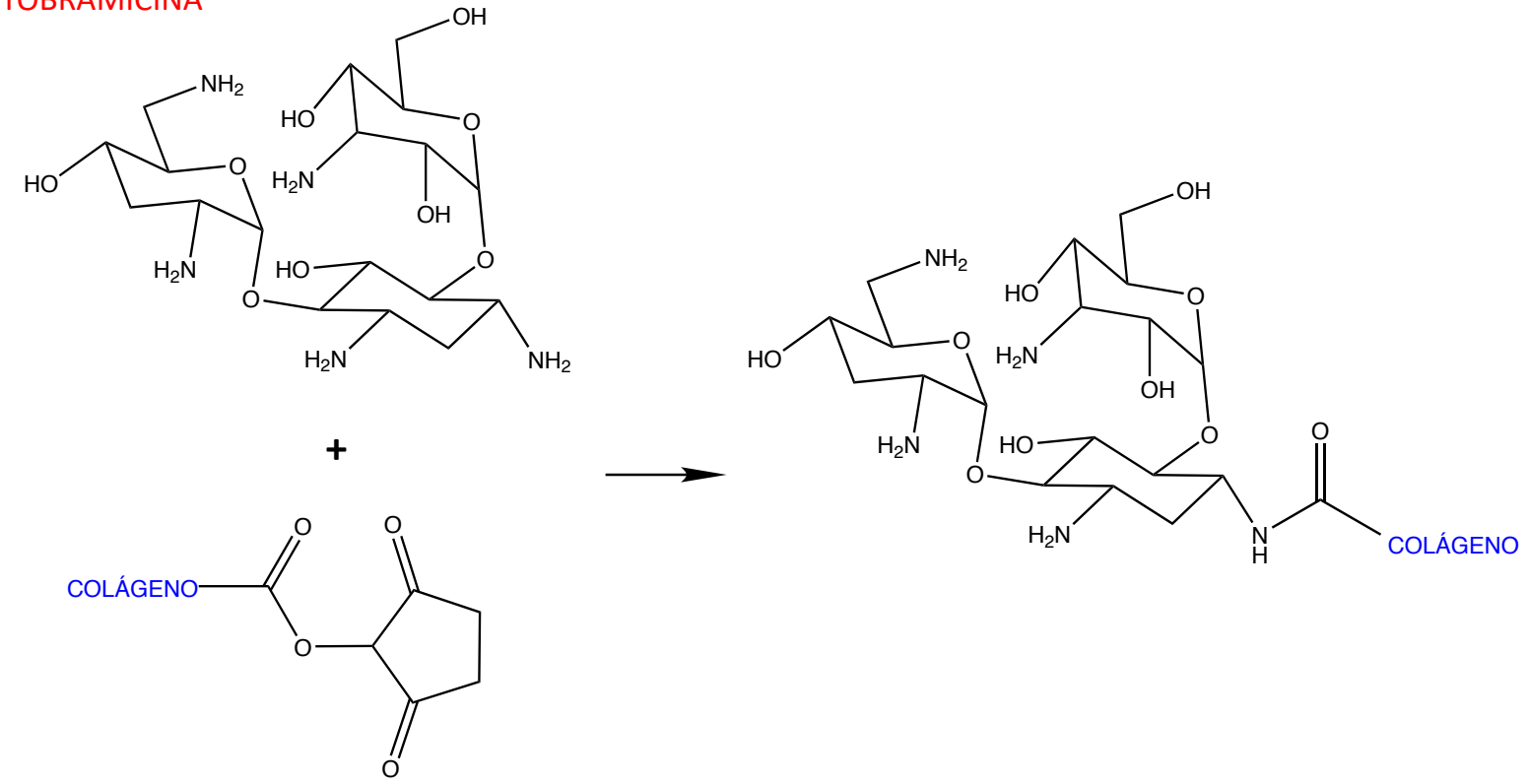


\section{Apêndice 2}

Membranas de A - PVA/C24/品/Tb e B - PVA/C72/GA/Tb obtidas por ligação covalente de tobramicina.

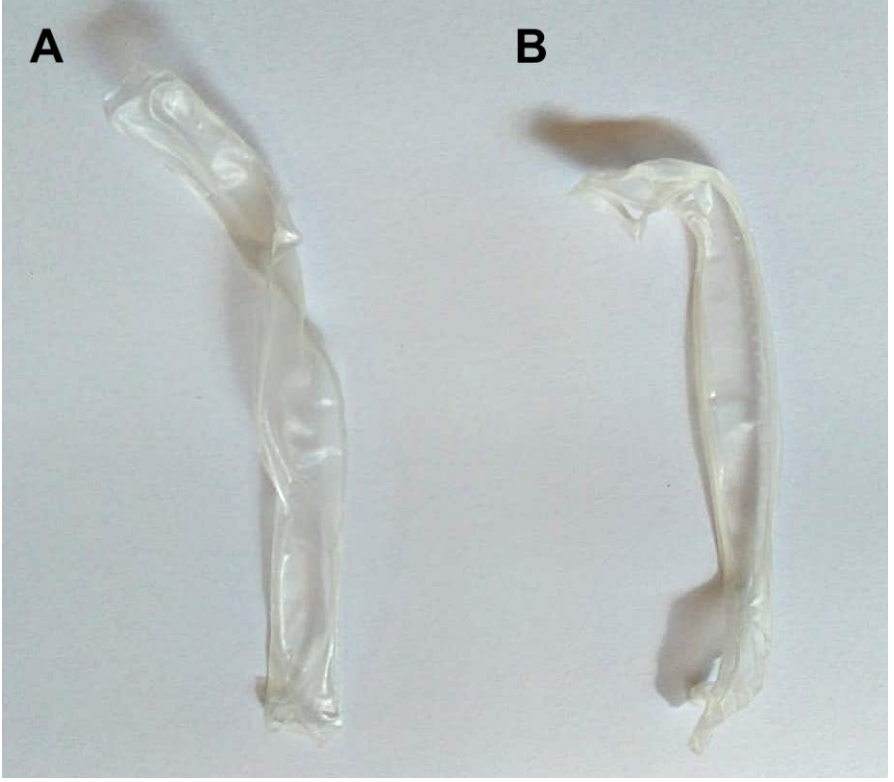

Membrana de A - PVA/C24, membranas de B - PVA/C24/Cpx e C - PVA/C24/Cfl obtidas por mistura no processo de obtenção, e membrana de D - PVA/C24/Tb obtida por absorção.

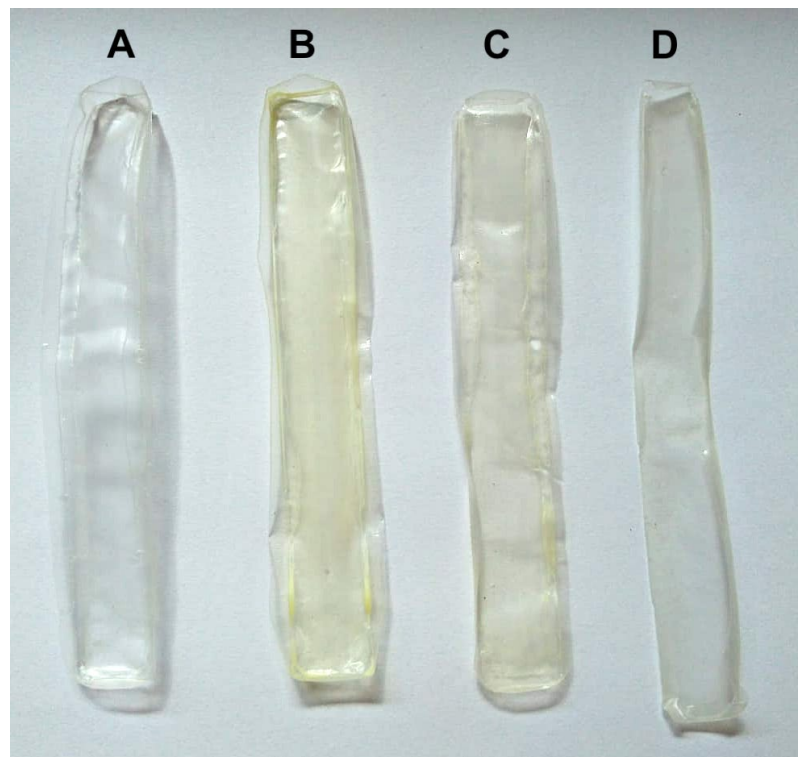


Membrana de A - PVA/C24, membranas de B - PVA/C24/Cpx e C - PVA/C24/Cfl obtidas por mistura no processo de obtenção, e membrana de D - PVA/C24/Tb obtida por absorção.

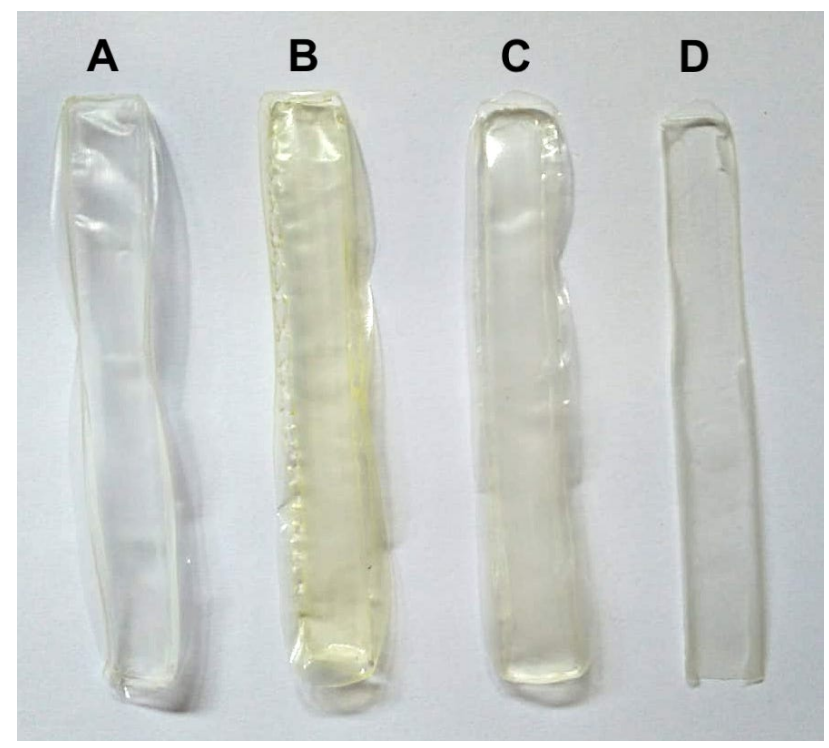




\section{Apêndice 3}

Ajuste dos dados de liberação de ciprofloxacina ao modelo de A. primeira ordem, B. Weibull, C. Hixson-Crowell, D. segunda ordem e E. Korsmeyer-Peppas para as membranas de PVA/C24/Cpx.
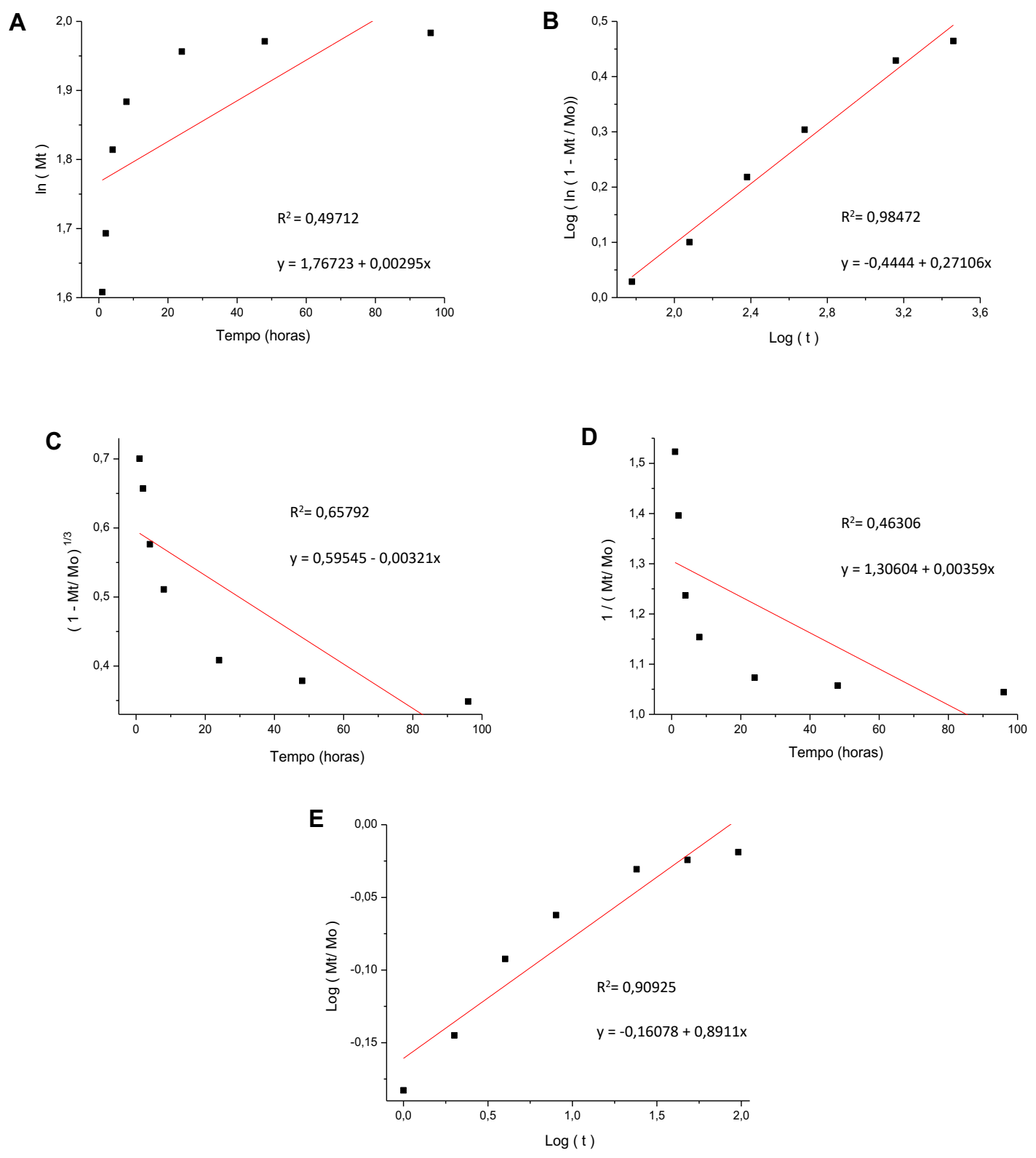


\section{Apêndice 4}

Cálculo da perda de massa das membranas por solubilidade.

Tendo em conta que a solubilidade experimental das membranas de PVA foi de $25 \%$ (Tabela 11), a solubilidade esperada para uma membrana de PVA/C24 de $x \mathrm{mg}$ é:

$$
\frac{x m g \times 0,75 \times 0,25}{x m g} \times 100 \approx 18 \%
$$

Para uma membrana de PVA/C24/Cpx de $x \mathrm{mg}$, onde $5 \%$ da massa é antibiótico com uma liberação de $96 \%$ após 48 h e o restante $95 \%$ é matriz polimérica, a solubilidade esperada é:

$$
\frac{x m g \times 0,95 \times 0,75 \times 0,25+x m g \times 0,05 \times 0,96}{x m g} \times 100 \approx 22 \%
$$

Finalmente para uma membrana de PVA/C24/Tb de $x \mathrm{mg}$, onde 7,9\% da massa é antibiótico com uma liberação de $37 \%$ após $48 \mathrm{~h}$ e o restante $82,1 \%$ é matriz polimérica, a solubilidade esperada é:

$$
\frac{x m g \times 0,821 \times 0,75 \times 0,25+x m g \times 0,079 \times 0,37}{x m g} \times 100 \approx 18 \%
$$

Mas se se considera que o PVA dissolveu durante a incorporação da tobramicina então a solubilidade esperada seria simplesmente:

$$
\frac{x m g \times 0,079 \times 0,37}{x m g} \times 100 \approx 3.0 \%
$$

Estas estimativas são muito próximas aos dados da Tabela 11, confirmando que a perda de massa das membranas se deu pela solubilidade do PVA e a liberação dos antibióticos. 


\section{ANEXOS}

\section{Anexo 1}

Modelos matemáticos usados para analisar a liberação da ciprofloxacina (item 5.4).

\section{Primeira ordem:}

$$
\ln Q_{\mathrm{t}}=\ln \mathrm{Q}_{0}+\mathrm{K}_{1} \mathrm{t}
$$

Onde $\mathbf{Q}_{t}$ é a quantidade de fármaco liberado ao tempo $t, \mathbf{Q}_{0}$ é a quantidade de fármaco em solução ao inicio da liberação e $\mathbf{K}_{\mathbf{1}}$ é a constante de liberação. Nos sistemas que se ajustam a este modelo a quantidade de fármaco liberada a cada tempo é proporcional à quantidade de fármaco remanente no interior do material.

\section{Segunda ordem:}

$$
\frac{1}{Q_{t}}=\frac{1}{Q_{0}}+K_{2} t
$$

Onde $Q_{t}$ é a quantidade de fármaco liberado ao tempo $t, Q_{0}$ é a quantidade de fármaco em solução ao inicio da liberação e $K_{2}$ é a constante de liberação (COSTA; LOBO, 2001). Nos sistemas que se ajustam a este modelo a quantidade de fármaco liberado a cada tempo é proporcional ao quadrado da quantidade de fármaco remanente no interior do material.

\section{Hixson-Crowell:}

$$
\mathrm{W}_{0}^{1 / 3}-\mathrm{W}_{\mathrm{t}}^{1 / 3}=\mathrm{K}_{\mathrm{s}} \mathrm{t}
$$

Onde $\mathbf{W}_{\mathbf{0}}$ é a quantidade de fármaco na membrana ao inicio da liberação, $\mathbf{W}_{\mathbf{t}}$ é a quantidade de fármaco remanente na membrana ao tempo $\mathbf{t}$ e $\mathbf{K}_{\mathrm{s}}$ é uma constante de incorporação que relaciona a superfície e o volume da membrana. Este modelo descreve sistemas onde a liberação se dá em planos paralelos à superfície do material (mantendo a geometria do material constante) (COSTA; LOBO, 2001).

\section{Korsmeyer-Peppas:}

Este modelo é baseado na equação semi-empírica introducida por Korsmeyer et al. (1983).

$$
\frac{\mathrm{M}_{\mathrm{t}}}{\mathrm{M}_{0}}=\mathrm{Kt}^{\mathrm{n}}
$$


Que pode ser reorganizada na forma logarítmica.

$$
\ln \frac{\mathrm{M}_{\mathrm{t}}}{\mathrm{M}_{0}}=\ln \mathrm{K}+\mathrm{n} \ln \mathrm{t}
$$

Onde $\mathbf{M}_{\mathbf{0}}$ é a quantidade de fármaco contida na membrana ao inicio da liberação, $\mathbf{M}_{\mathbf{t}}$ é a quantidade de fármaco liberada ao tempo $\mathbf{t}$, $\mathbf{K}$ é a constante liberação e $\mathbf{n}$ é o exponente de liberação (relacionado ao mecanismo de liberação). Este modelo é usado em sistemas onde o mecanismo de liberação não é bem compreendido ou mais de um processo esta envolvido na liberação do fármaco (LOPES; LOBO; COSTA, 2006). Quando o valor de $\mathbf{n}=0,5$ o mecanismo predominante é a difusão (denominado caso I ou modelo Fickiano) e quando $\mathbf{n}=1$ o mecanismo predominante é o intumescimento ou a relaxação das cadeias poliméricas (denominado caso II ou modelo não Fickiano). Para mais detalhes sobre este modelo consultar o artigo de Lopes, Lobo e Costa (2006). 


\section{REFERÊNCIAS BIBLIOGRÁFICAS}

AMERICAN SOCIETY FOR TESTING AND MATERIALS. Standard Test Method for Transparency of Plastic Sheeting, ASTM D1746 - 09. West Conshohocken. 2009. p. 1-4.

AMERICAN SOCIETY FOR TESTING AND MATERIALS. Standard Test Method for Tensile Properties of Thin Plastic Sheeting, D882-02. West Conshohocken. 2002. p. $1-10$

AMERICAN SOCIETY FOR TESTING AND MATERIALS. Standard Test Methods for Water Vapor Transmission of Material, E96-95. Philadelphia. 1995. p. 1-8.

AGBAN, Y.; LIAN, J.; PRABAKAR, S.; SEYFODDIN, A.; RUPENTHAL, I. D. Nanoparticle cross-linked collagen shields for sustained delivery of pilocarpine hydrochloride. International Journal of Pharmaceutics, v. 501, n. 1-2, p. 96-101, 2016.

ALBERTS, B.; JOHNSON, A.; LEWIS, J.; RAFF, M.; ROBERTS, K.; WALTER, P. Molecular Biology of the Cell. [s.I.] Garland Science, 2002.

ARNOCZKY, S. P.; AKSAN, A. Thermal modification of connective tissues: basic science considerations and clinical implications. The Journal of the American Academy of Orthopaedic Surgeons, v. 8, n. 5, p. 305-13, 2000.

BADEA, E.; MIU, L.; BUDRUGEAC, P.; GIURGINCA, M.; MAŠIĆ, a.; BADEA, N.; DELLA GATTA, G. Study of deterioration of historical parchments by various thermal analysis techniques complemented by SEM, FTIR, UV-Vis-NIR and unilateral NMR investigations. Journal of Thermal Analysis and Calorimetry, v. 91, n. 1, p. 17-27, 2008.

BALASUBRAMANIAM, J.; SRINATHA, A.; PANDIT, J. K.; NATH, G. In vitro Microbiological Evaluation of Polyvinyl Alcohol-based Ocular Inserts of Ciprofloxacin Hydrochloride. Indian Journal of Pharmaceutical Sciences, v. 68, n. 5, p. 626630, 2006.

BENGANI, L. C.; HSU, K.; GAUSE, S.; CHAUHAN, A. Contact lenses as a platform for ocular drug delivery. Expert Opinion on Drug Delivery., v. 10, n. 11, p. 1-14, 2013.

BET, M. R.; GOISSIS, G.; LACERDA, C. A. Characterization of polyanionic collagen prepared by selective hydrolysis of asparagine and glutamine carboxyamide side chains. Biomacromolecules, v. 2, n. 4, p. 1074-9, 2001.

BOURLAIS, C. L.; ACAR, L.; ZIA, H.; SADO, P.; NEEDHAM, T.; LEVERGE, R. Ophthalmic drug delivery systems--recent advances. Progress in Retinal and Eye Research, v. 17, n. 1, p. 33-58, 1998.

BURKERSRODA, F. von; SCHEDL, L.; GÖPFERICH, A. Why degradable polymers undergo surface erosion or bulk erosion. Biomaterials, v. 23, n. 21, p. 4221-4231, 2002. 
BUSIN, M.; SPITZNAS, M. Sustained gentamicin release by presoaked medicated bandage contact lenses. Ophthalmology, v. 95, n. 6, p. 796-8, 1988.

CALLEGAN, M. C.; HOBDEN, J. A.; HILL, J. M.; INSLER, M. S.; O'CALLAGHAN, R. J. Topical antibiotic therapy for the treatment of experimental Staphylococcus aureus keratitis. Investigative Ophthalmology \& Visual Science, v. 33, n. 11, p. 3017-23, 1992.

CALLEGAN, M. C.; O'CALLAGHAN, R. J.; HILL, J. M. Pharmacokinetic considerations in the treatment of bacterial keratitis. Clinical Pharmacokinetics, v. 27 , n. 2, p. 129-149, 1994.

CARBINATTO, F. M.; DE CASTRO, A. D.; EVANGELISTA, R. C.; CURY, B. S. F. Insights into the swelling process and drug release mechanisms from cross-linked pectin/high amylose starch matrices. Asian Journal of Pharmaceutical Sciences, v. 9, n. 1, p. 27-34, 2014.

CARRIER, O.; BONN, D. Contact Angles and the Surface Free Energy of Solids. In: BRUTIN, D. (Ed.). Droplet Wetting and Evaporation. [s.I.] Academic Press, 2015. p. 15-23.

CHAK, V.; KUMAR, D.; VISHT, S. A review on collagen based drug delivery systems. International Journal of Pharmacy Teaching \& Practices, v. 4, n. 4, p. 811-820, 2013.

CHANG, P.-C.; LIU, B.-Y.; LIU, C.-M.; CHOU, H.-H.; HO, M.-H.; LIU, H.-C.; WANG, D.-M.; HOU, L.-T. Bone tissue engineering with novel rhBMP2-PLLA composite scaffolds. Journal of Biomedical Materials Research. Part A, v. 81, n. 4, p. 771780, 2007.

CHATTOPADHYAY, S.; RAINES, R. T. Review collagen-based biomaterials for wound healing. Biopolymers, v. 101, n. 8, p. 821-833, 2014.

CHIFIRIUC, M. C.; GRUMEZESCU, A. M.; GRUMEZESCU, V.; BEZIRTZOGLOU, E.; LAZAR, V.; BOLOCAN, A. Biomedical Applications of Natural Polymers for Drug Delivery. Current Organic Chemistry, v. 18, n. 2, p. 152-164, 2014.

CIOLINO, J. B.; HOARE, T. R.; IWATA, N. G.; BEHLAU, I.; DOHLMAN, C. H.; LANGER, R.; KOHANE, D. S. A Drug-Eluting Contact Lens. Investigative Opthalmology \& Visual Science, v. 50, n. 7, p. 3346-3352, 2009.

CIOLINO, J. B.; HUDSON, S. P.; MOBBS, A. N.; HOARE, T. R.; IWATA, N. G.; FINK, G. R.; KOHANE, D. S. A prototype antifungal contact lens. Investigative Ophthalmology \& Visual Science, v. 52, n. 9, p. 6286-91, 2011.

COSTA, P.; LOBO, J. M. S. Modelling and Comparison of Dissolution Profiles. European Journal of Pharmaceutical Science, v. 13, p. 123-133, 2001.

DASH, A. K.; CUDWORTH, G. C. Therapeutic applications of implantable drug delivery systems. Journal of Pharmacological and Toxicological Methods, v. 40, n. 1, p. 1-12, 1998.

DE SOUSA, M. A. Preparação e caracterização de matrizes de colágeno como suporte de crescimento de tecidos e liberação controlada de antibioticos. [s.I.] 
Universidade de São Paulo, São Carlos, 2001.

DU, W.; JIANG, L.; SHI, M.; YANG, Z.; ZHANG, X. The modification mechanism and the effect of magnesium chloride on poly(vinyl alcohol) films. RSC Advances, v. 9, $\mathrm{n}$. 3, p. 1602-1612, 2019.

DUAN, X.; SHEARDOWN, H. Dendrimer crosslinked collagen as a corneal tissue engineering scaffold: Mechanical properties and corneal epithelial cell interactions. Biomaterials, v. 27, n. 26, p. 4608-4617, 2006.

DUBIELZIG, R. R.; KETRING, K.; MCLELLAN, G. J.; ALBERT, D. M. Veterinary Ocular Pathology. Edinburgh: Saunders elsevier, 2010.

EFRON, N. Rigid Lens Materials. In: EFRON, N. (Ed.). Contact Lens Practice. 3. ed. [s.I.] Elsevier, 2018. p. 115-122.

ESHAR, D.; WYRE, N. R.; SCHOSTER, J. V. Use of collagen shields for treatment of chronic bilateral corneal ulcers in a pet rabbit. Journal of Small Animal Practice, v. 52, n. 7, p. 380-383, 2011.

FALATH, W.; SABIR, A.; JACOB, K. I. Highly improved reverse osmosis performance of novel PVA/DGEBA cross-linked membranes by incorporation of Pluronic F-127 and MWCNTs for water desalination. Desalination, v. 397, p. 53-66, 2016.

FLECK, C. A.; SIMMAN, R. Modern collagen wound dressings: Function and purpose. Journal of the American College of Certified Wound Specialists, v. 2, n. 3, p. 50-54, 2010.

GARHWAL, R.; SHADY, S. F.; ELLIS, E. J.; ELLIS, J. Y.; LEAHY, C. D.; MCCARTHY, S. P.; CRAWFORD, K. S.; GAINES, P. Sustained ocular delivery of ciprofloxacin using nanospheres and conventional contact lens materials.

Investigative Ophthalmology and Visual Science, v. 53, n. 3, p. 1341-1352, 2012.

GAUDANA, R.; ANANTHULA, H. K.; PARENKY, A.; MITRA, A. K. Ocular drug delivery. The AAPS Journal, v. 12, n. 3, p. 348-360, 2010.

GAVARA, R.; COMPAÑ, V. Oxygen, water, and sodium chloride transport in soft contact lenses materials. Journal of Biomedical Materials Research B: Applied Biomaterials, v. 105, n. 8, p. 2218-2231, 2017.

GELATT, K. N. Essentials of Veterinary Ophthalmology. 3. ed. Gainesville: Wiley Blackwell, 2014.

GHANBARZADEH, B.; ALMASI, H.; ENTEZAMI, A. A. Physical properties of edible modified starch/carboxymethyl cellulose films. Innovative Food Science and Emerging Technologies, v. 11, n. 4, p. 697-702, 2010.

GHATE, D.; EDELHAUSER, H. F. Ocular drug delivery. Expert Opinion on Drug Delivery, v. 3, n. 2, p. 275-287, 2006.

GIGLIOTI, A. F. Um processo automático par a reticulação progressiva do pericárdio bovino por meio de gradiente de concentração linear do glutraldeído. Universidade de São Paulo, São Carlos, 2000 
GIRALDEZ, M. J.; YEBRA-PIMENTEL, E. Hydrogel Contact Lenses Surface Roughness and Bacterial Adhesion. In: ADIO, A. (Ed.). Ocular Diseases. [s.I.] IntechOpen, 2012. p. 95-120.

GUZMAN-ARANGUEZ, A.; COLLIGRIS, B.; PINTOR, J. Contact Lenses : Promising Devices for Ocular Drug Delivery. Journal of Ocular Pharmacology and Therapeutics, v. 29, n. 2, p. 189-199, 2013.

HAJARE, A.; SALUNKHE, S.; NADAF, S.; BHATIA, N.; BAGAL, P.; GAIKWAD, S.; PAWAR, K. A RATIONAL APPROACH TO OCULAR DRUG DELIVERY SYSTEMS : A OVERVIEW. World Journal of Pharmaceutical Research, v. 3, n. 2, p. 33243348, 2014.

HASSIBA, A. J.; ZOWALATY, M. E. E. Z.; WEBSTER, T. J. W.; ABDULLAH, A. M.; NASRALLAH, G. K.; KHALIL, K. A. K.; LUYT, A. S.; ELZATAHRY, A. A. Synthesis, characterization, and antimicrobial properties of novel double layer nanocomposite electrospun fibers for wound dressing applications. International Journal of Nanomedicine, n. 12, p. 2205-2213, 2017.

HOBDEN, J. A. Pseudomonas aeruginosa Proteases and Corneal Virulence. DNA and Cell Biology, v. 21, n. 5-6, p. 391-396, 2002.

HOLOWKA, E. P.; BHATIA, S. K. Drug Delivery - Materials Design and Clinical Perspective. New York: Springer, 2014.

HULMES, D. J. S. Collagen Diversity, Synthesis and Assembly. In: FRATZL, P. (Ed.). Collagen: Structure and Mechanics. [s.I.] Springer US, 2008. p. 15-47.

HYNDIUK, R. A. Experimental Pseudomonas keratitis. Transactions of the American Ophthalmological Society, v. 79, p. 541-624, 1981.

HYNDIUK, R. A.; EIFERMAN, R. A.; CALDWELL, D. R.; ROSENWASSER, G. O.; SANTOS, C. I.; KATZ, H. R.; BADRINATH, S. S.; REDDY, M. K.; ADENIS, J.-P.; KLAUSS, V.; ADENIS, J. P.; BADRINATH, S. S.; ... WOLF, T. C. Comparison of Ciprofloxacin Ophthalmic Solution $0.3 \%$ to Fortified Tobramycin-Cefazolin in Treating Bacterial Corneal Ulcers. Ophthalmology, v. 103, n. 11, p. 1854-1863, 1996.

IANDOLO, J. J. Genetic Analysis of Extracellular Toxins of Staphylococcus Aureus. Annual Review of Microbiology, v. 43, n. 1, p. 375-402, 1989.

IBÁÑEZ-REDÍN, G.; WILSON, D.; GONÇALVES, D.; OLIVEIRA, O. N. Low-cost screen-printed electrodes based on electrochemically reduced graphene oxidecarbon black nanocomposites for dopamine, epinephrine and paracetamol detection. Journal of Colloid and Interface Science, v. 515, p. 101-108, 2018.

JACOBS, D. S.; JOHNS, L. K.; LE, H.-G. Contact Lenses for Ocular Surface Disease. In: HOLLAND, E. J.; MANNIS, M. J.; LEE, W. B. (Ed.). Ocular Surface Disease: Cornea, Conjunctiva and Tear Film. [s.I.] W.B. Saunders, 2013. p. 283291.

JAIN, D.; CARVALHO, E.; BANTHIA, A. K.; BANERJEE, R. Development of polyvinyl alcohol gelatin membranes for antibiotic delivery in the eye. Drug Development and Industrial Pharmacy, v. 37, n. 2, p. 167-177, 2011. 
JAIN, V.; KARE, P.; JAIN, D.; SINGH, R. Development and characterization of mucoadhesive nanosuspension of ciprofloxacin. Acta Poloniae Pharmaceutica Drug Research, v. 68, n. 2, p. 273-278, 2011 b.

JHANJI, V.; YOUNG, A. L.; MEHTA, J. S.; SHARMA, N.; AGARWAL, T.; VAJPAYEE, R. B. Management of Corneal Perforation. Survey of Ophthalmology, v. 56, n. 6, p. 522-538, 2011.

JIANG, H.; ZUO, Y.; ZHANG, L.; LI, J.; ZHANG, A.; LI, Y.; YANG, X. Property-based design: Optimization and characterization of polyvinyl alcohol (PVA) hydrogel and PVA-matrix composite for artificial cornea. Journal of Materials Science: Materials in Medicine, v. 25, n. 3, p. 941-952, 2014a.

JOSHI, J. a Y. R.; PATEL, R. P. Role of biodegradable polymers in drug delivery. International Journal of Current Pharmaceutical Research, v. 4, n. 4, p. 74-81, 2012.

KANUNGO, I.; FATHIMA, N. N.; RAO, J. R.; NAIR, B. U. Hydration dynamics of collagen/PVA composites: Thermoporometric and impedance analysis. Materials Chemistry and Physics, v. 140, n. 1, p. 357-364, 2013.

KHAN, R.; KHAN, M. H. Use of collagen as a biomaterial: An update. Journal of Indian Society of Periodontology, v. 17, n. 4, p. 539-42, 2013.

KHOKHAR, P. Design and Characterisation of Chloramphenicol Ocular Insert for Ocular Drug. International Journal of Pharma Research \& Review, v. 4, n. 2, p. 915, 2015.

KIKUCHI, H.; SAKAI, T.; TESHIMA, R.; NEMOTO, S.; AKIYAMA, H. Total determination of chloramphenicol residues in foods by liquid chromatography-tandem mass spectrometry. Food Chemistry, v. 230, p. 589-593, 2017.

KIM, J. Y.; WON, H.-J.; SOON-WUK, J. A retrospective study of ulcerative keratitis in 32 Dogs. The International Journal of Applied Research in Veterinary Medicine, v. 7, n. 1, p. 27-31, 2009.

KOLAKOVIC, R.; PELTONEN, L.; LAUKKANEN, A.; HIRVONEN, J.; LAAKSONEN, T. Nanofibrillar cellulose films for controlled drug delivery. European Journal of Pharmaceutics and Biopharmaceutics, v. 82, p. 308-315, 2012.

KORSMEYER, R. W.; GURNY, R.; DOELKER, E.; BURI, P.; PEPPAS, N. A. Mechanisms of solute release from porous hydrophilic polymers. International Journal of Pharmaceutics, v. 15, n. 1, p. 25-35, 1983.

KUNO, N.; FUJII, S. Recent advances in ocular drug delivery systems. Polymers, v. 3, n. 1, p. 193-221, 2011.

LACERDA, C.; PLEPIS, M. D. G.; GOISSIS, G. Hidrólise seletiva de carboxiamidas de resíduos de asparagina e glutamina em colágeno: preparação e caracterização de matrizes aniônicas para uso como biomateriais. Química Nova, v. 21, n. 3, p. 267-271, 1998.

LAM, R. F.; LAI, J. S. M.; NG, J. S. K.; RAO, S. K.; LAW, R. W. K.; LAM, D. S. C. Topical chloramphenicol for eye infections. Hong Kong Medical Journal, v. 8, n. 1, 
p. 44-47, 2002.

LANGER, R. New methods of drug delivery. Science, v. 249, n. 4976, p. 1527-33, 1990.

LEE, C. H.; SINGLA, A.; LEE, Y. Biomedical applications of collagen. International Journal of Pharmaceutics, v. 221, n. 1-2, p. 1-22, 2001.

LI, G.; GU, X.; SONG, H.; NAN, K.; CHEN, H. Biocompatibility and drug release behavior of chitosan / poly ( vinyl alcohol ) corneal shield in vivo. International Journal of Clinical and Experimental Medicine, v. 8, n. 8, p. 12949-12955, 2015.

LIECHTY, W. B.; KRYSCIO, D. R.; SLAUGHTER, B. V.; PEPPAS, N. a. Polymers for Drug Delivery Systems. Annual Review of Chemical and Biomolecular

Engineering, v. 1, n. 1, p. 149-173, 2010.

LIU, Y.; LV, H.; REN, L.; XUE, G.; WANG, Y. Improving the moisturizing properties of collagen film by surface grafting of chondroitin sulfate for corneal tissue engineering. Journal of Biomaterials Science, Polymer Edition, v. 27, n. 8, p. 758-772, 2016.

LIU, Y.; REN, L.; LONG, K.; WANG, L.; WANG, Y. Preparation and characterization of a novel tobramycin-containing antibacterial collagen film for corneal tissue engineering. Acta Biomaterialia, v. 10, n. 1, p. 289-299, 2014.

LLOYD, A. W.; FARAGHER, R. G. a; DENYER, S. P. Ocular biomaterials and implants. Biomaterials, v. 22, n. 8, p. 769-785, 2001.

LOPES, C. M.; LOBO, J. M. S.; COSTA, P. Formas farmacêuticas de liberação modificada: polímeros hidrifílicos. Revista Brasileira de Ciências Farmacêuticas, v. 41, n. 2, p. 143-154, 2006.

MABROUK, M.; MOSTAFA, A. A.; OUDADESSE, H.; MAHMOUD, A. A.; ELGOHARY, M. I. Effect of ciprofloxacin incorporation in PVA and PVA bioactive glass composite scaffolds. Ceramics International, v. 40, n. 3, p. 4833-4845, 2014.

MAGGS, D.; MILLER, P.; OFRI, R. Slatter's Fundamentals of Veterinary

Ophthalmology. 4. ed. St. Louis: Saunders elsevier, 2008.

MCELVANNEY, A. M. Doxycycline in the Management of Pseudomonas Corneal Melting. Eye \& Contact Lens: Science \& Clinical Practice, v. 29, n. 4, p. 258-261, 2003.

MEEK, K. M.; KNUPP, C. Corneal structure and transparency. Progress in Retinal and Eye Research, v. 49, p. 1-16, 2015.

MENDIETA-TABOADA, O.; SOBRAL, P. J. do A.; CARVALHO, R. A.; HABITANTE, A. M. B. Q. Thermomechanical properties of biodegradable films based on blends of gelatin and poly(vinyl alcohol). Food Hydrocolloids, v. 22, n. 8, p. 1485-1492, 2008.

MIYASHITA, H.; SHIMMURA, S.; KOBAYASHI, H.; TAGUCHI, T.; ASANO-KATO, N.; UCHINO, Y.; KATO, M.; SHIMAZAKI, J.; TANAKA, J.; TSUBOTA, K. Collagenimmobilized poly(vinyl alcohol) as an artificial cornea scaffold that supports a stratified corneal epithelium. Journal of Biomedical Materials Research - Part B Applied Biomaterials, v. 76, n. 1, p. 56-63, 2006. 
MUNDADA, a S.; SHRIKHANDE, B. K. Formulation and evaluation of ciprofloxacin hydrochloride soluble ocular drug insert. Current Eye Research, v. 33, n. 5, p. 469475, 2008.

MUNDADA, A. S.; SHRIKHANDE, B. K. Design and evaluation of soluble ocular drug insert for controlled release of ciprofloxacin hydrochloride. Drug Development and Industrial Pharmacy, v. 32, n. 4, p. 443-448, 2006.

NGUYEN, D.; HUI, A.; WEEKS, A.; HEYNEN, M.; JOYCE, E.; SHEARDOWN, H.; JONES, L. Release of Ciprofloxacin-HCl and Dexamethasone Phosphate by Hyaluronic Acid Containing Silicone Polymers. Materials, v. 5, n. 12, p. 684-698, 2012.

NITHYA, V.; BHASKAR, A. A REVIEW ON MICROBIAL KERATITIS. World Journal of Pharmaceutical Research, v. 2, n. 5, p. 1466-1474, 2013.

O'BRIEN, T. P. Management of bacterial keratitis: beyond exorcism towards consideration of organism and host factors. Eye, v. 17, n. 8, p. 957-974, 2003.

OGAWA, C. A.; PLEPIS, A. M. G. Liberação In Vitro de Cloridrato de Ciprofloxacina em Compósitos Hidroxiapatita: Colágeno. Polímeros, v. 12, n. 2, p. 115-122, 2002.

OLLIVIER, F. J. Bacterial corneal diseases in dogs and cats. Clinical Techniques in Small Animal Practice, v. 18, n. 3, p. 193-8, 2003.

OLLIVIER, F. J.; GILGER, B. C.; BARRIE, K. P.; KALLBERG, M. E.; PLUMMER, C. E.; O'REILLY, S.; GELATT, K. N.; BROOKS, D. E. Proteinases of the cornea and preocular tear film. Veterinary Ophthalmology, v. 10, n. 4, p. 199-206, 2007.

PARENTEAU-BAREIL, R.; GAUVIN, R.; BERTHOD, F. Collagen-based biomaterials for tissue engineering applications. Materials, v. 3, n. 3, p. 1863-1887, 2010.

PENG, Z.; LI, Z.; ZHANG, F.; PENG, X. Preparation and Properties of Polyvinyl Alcohol/Collagen Hydrogel. Journal of Macromolecular Science, Part B, v. 51, n. March 2015, p. 1934-1941, 2012.

PRADO, M. R.; BRITO, E. H. S.; GIRÃO, M. D.; SIDRIM, J. J. C.; ROCHA, M. F. G. Identification and antimicrobial susceptibility of bacteria isolated from corneal ulcers of dogs. Arquivo Brasileiro de Medicina Veterinária e Zootecnia, v. 58, n. 6, p. 1024-1029, 2006.

PUOCI, F.; PIANGIOLINO, C.; GIVIGLIANO, F.; PARISI, O. I.; CASSANO, R.; TROMBINO, S.; CURCIO, M.; IEMMA, F.; CIRILLO, G.; SPIZZIRRI, U. G.; RESTUCCIA, D.; MUZZALUPO, R.; PICCI, N. Ciprofloxacin-collagen conjugate in the wound healing treatment. Journal of Functional Biomaterials, v. 3, n. 2, p. 361-371, 2012.

RAD, M. S.; MOHAJERI, S. A. Simultaneously Load and Extended Release of Betamethasone and Ciprofloxacin from Vitamin E-Loaded Silicone-Based Soft Contact Lenses. Current Eye Research, v. 41, n. 9, p. 1185-1191, 2016.

RATHORE, K.; NEMA, R. An insight into ophthalmic drug delivery system. International Journal of Pharmaceutical Sciences and Drug Research, v. 1, p. 1$5,2009$. 
ROBIN, J. B.; KEYS, C. L.; KAMINSKI, L. a.; VIANA, M. a. G. The effect of collagen shields on rabbit corneal reepithelialization after chemical debridement.

Investigative Ophthalmology and Visual Science, v. 31, n. 7, p. 1294-1300, 1990.

RODRIGUES, F. T. Desenvolvimento de membranas acelulares de colágeno derivadas de pericárdio porcino para uso em engenharia de tecido. [s.l.] Universidade de São Paulo, São Carlos, 2011.

RYAN, J. A. Colorimetric determination of gentamicin, kanamycin, tobramycin, and amikacin aminoglycosides with 2,4-dinitrofluorobenzene. Journal of Pharmaceutical Sciences, v. 73, n. 9, p. 1301-2, 1984.

SÁEZ, V.; HERNÁEZ, E.; LÓPEZ, L. Liberación controlada de fármacos. aplicaciones biomédicas. Revista Iberoamericana Polímeros, v. 4, n. 2, p. 111122, 2003.

SARTI, B.; SCANDOLA, M. Viscoelastic and thermal properties of collagen/poly(vinyl alcohol) blends. Biomaterials, v. 16, n. 10, p. 785-792, 1995.

SCHAEFER, F.; BRUTTIN, O.; ZOGRAFOS, L.; GUEX-CROSIER, Y. Bacterial keratitis: a prospective clinical and microbiological study. The British Journal of Ophthalmology, v. 85, n. 7, p. 842-847, 2001.

SHAIK, M. R.; KORSAPATI, M.; PANATI, D. Polymers in Controlled Drug Delivery Systems. International Journal of Pharma Sciences, v. 2, n. 4, p. 112-116, 2012.

SHI, Y.; LV, H.; FU, Y.; LU, Q.; ZHONG, J.; MA, D.; HUANG, Y.; XUE, W. Preparation and characterization of a hydrogel carrier to deliver gatifloxacin and its application as a therapeutic contact lens for bacterial keratitis therapy. Biomedical Materials, v. 8, n. 5, 2013.

SILBIGER, J.; STERN, G. A. Evaluation of corneal collagen shields as a drug delivery device for the treatment of experimental Pseudomonas keratitis.

Ophthalmology, v. 99, n. 6, p. 889-892, 1992.

SIMŞEK, N. A.; AY, G. M.; TUGAL-TUTKUN, I.; BAŞAR, D.; BILGIN, L. K. An experimental study on the effect of collagen shields and therapeutic contact lenses on corneal wound healing. Cornea, v. 15, n. 6, p. 612-616, 1996.

SIONKOWSKA, A.; PŁANECKA, A.; KOZŁOWSKA, J.; SKOPIŃSKA-WIŚNIEWSKA, J. Surface properties of UV-irradiated poly(vinyl alcohol) films containing small amount of collagen. Applied Surface Science, v. 255, n. 7, p. 4135-4139, 2009.

SIONKOWSKA, A.; SKOPIŃSKA, J.; WISNIEWSKI, M. Photochemical stability of collagen/poly (vinyl alcohol) blends. Polymer Degradation and Stability, v. 83, n. 1, p. 117-125, 2004.

SRIPRIYA, R.; KUMAR, M. S.; SEHGAL, P. K. Improved collagen bilayer dressing for the controlled release of drugs. Journal of Biomedical Materials Research, v. 70B, n. 2, p. 389-396, 2004.

STARTUP, F. G. Corneal ulceration in the dog. Journal of Small Animal Practice, v. 25, n. 12 , p. $737-752,1984$. 
STYLIANOU, A. Atomic force microscopy for collagen-based nanobiomaterials. Journal of Nanomaterials, v. 2017, 2017.

STYLIANOU, A.; YOVA, D.; ALEXANDRATOU, E. Nanotopography of collagen thin films in correlation with fibroblast response. Journal of Nanophotonics, v. 7, n. 1, p. 1-16, 2013.

STYLIANOU, A.; YOVA, D.; ALEXANDRATOU, E. Investigation of the influence of UV irradiation on collagen thin films by AFM imaging. Materials Science and Engineering C, v. 45, p. 455-468, 2014.

SUDHAMANI, S. R.; PRASAD, M. S.; SANKAR, K. U. DSC and FTIR studies on Gellan and Polyvinyl alcohol ( PVA ) blend films. Food Hydrocolloids, v. 17, p. 245250, 2003.

SUEKE, H.; SHANKAR, J.; NEAL, T. J.; HORSBURGH, M.; GILBERT, R.; KAYE, S. B. New Developments in Antibacterial Chemotherapy for Bacterial Keratitis. In: REINHARD, T.; LARKIN, F. (Ed.). Corneal Disease. New York: Springer Berlin Heidelberg, 2013. p. 19-35.

SUZUKI, K.; SAITO, J.; YANAI, R.; YAMADA, N.; CHIKAMA, T.; SEKI, K.; NISHIDA, T. Cell-matrix and cell-cell interactions during corneal epithelial wound healing.

Progress in Retinal and Eye Research, v. 22, p. 113-133, 2003.

THOMAS, S.; GROHENS, Y.; JYOTISHKUMAR, P. (ed.). Characterization of Polymer Blends. Weinheim, Germany: Wiley-VCH Verlag GmbH \& Co. KGaA, 2014.

THOMPSON, A. M. Ocular toxicity of fluoroquinolones. Clinical \& Experimental Ophthalmology, v. 35, n. 6, p. 566-77, 2007.

TOLAR, E. L.; HENDRIX, D. V. H.; ROHRBACH, B. W.; PLUMMER, C. E.; BROOKS, D. E.; GELATT, K. N. Evaluation of clinical characteristics and bacterial isolates in dogs with bacterial keratitis: 97 cases (1993-2003). Journal of the American Veterinary Medical Association, v. 228, n. 1, p. 80-85, 2006.

TRANOUDIS, I.; EFRON, N. Tensile properties of soft contact lens materials. Contact Lens and Anterior Eye, v. 27, n. 4, p. 177-191, 2004.

UCHEGBU, I. F.; SCHATZLEIN, A. G. Polymers in Drug Delivery. Boca Raton: Taylor \& Francis Group, 2006.

UNTERMAN, S. R.; ROOTMAN, D. S.; HILL, J. M.; PARELMAN, J. J.; THOMPSON, H. W.; KAUFMAN, H. E. Collagen shield drug delivery: Therapeutic concentrations of tobramycin in the rabbit cornea and aqueous humor. Journal of Cataract \& Refractive Surgery, v. 14, n. 5, p. 500-504, 1988.

VASILIKI, P.; KOSMIDIS, K.; VLACHOU, M.; MACHERAS, P. On the use of the Weibull function for the discernment of drug release mechanisms. International Journal of Pharmaceutics, v. 108, n. 6, p. 349-354, 2015.

VILAR, G.; TULLA-PUCHE, J.; ALBERICIO, F. Polymers and Drug Delivery Systems. Current Drug Delivery, v. 9, n. 4, p. 1-28, 2012.

VONGSAKUL, S.; TUNTIVANICH, P.; SIRIVAIDYAPONG, S.; KALPRAVIDH, M. 
Canine amniotic membrane transplantation for ocular surface reconstruction of created deep corneal ulcers in dogs. Thai Journal of Veterinary Medicine, v. 39, n. 2, p. 135-144, 2009.

WEISSMAN, B. A.; LEE, D. A. Oxygen Transmissibility, Thickness, and Water Content of Three Types of Collagen Shields. Archives of Ophthalmology, v. 106, p. 1706-1708, 1988.

WHITLEY, R. D. Canine and Feline Primary Ocular Bacterial Infections. Veterinary Clinics of North America: Small Animal Practice, v. 30, n. 5, p. 1151-1167, 2000.

WILLOUGHBY, C. E.; BATTERBURY, M.; KAYE, S. B. Collagen corneal shields. Survey of Ophthalmology, v. 47, n. 2, p. 174-182, 2002.

WU, Z.; KONG, B.; LIU, R.; SUN, W.; MI, S. Engineering of Corneal Tissue through an Aligned PVA/Collagen Composite Nanofibrous Electrospun Scaffold.

Nanomaterials (Basel, Switzerland), v. 8, n. 2, 2018.

YANG, H.; XU, S.; JIANG, L.; DAN, Y. Thermal decomposition behavior of poly (vinyl alcohol) with different hydroxyl content. Journal of Macromolecular Science, Part B: Physics, v. 51, n. 3, p. 464-480, 2012.

YANG, W.-W.; PIERSTORFF, E. Reservoir-Based Polymer Drug Delivery Systems. Journal of Laboratory Automation, v. 17, n. 1, p. 50-58, 2012.

YANOFF, M.; DUKER, J. S. Ophthalmology. 4. ed. China: Saunders Elsevier, 2014.

YU, X.; TANG, C.; XIONG, S.; YUAN, Q.; GU, Z.; LI, Z.; HU, Y. Modification of Collagen for Biomedical Applications: A Review of Physical and Chemical Methods. Current Organic Chemistry, v. 20, n. 17, p. 1797-1812, 2016.

ZHU, G.; WANG, F.; XU, K.; GAO, Q.; LIU, Y. Study on Properties of Poly ( vinyl alcohol )/ Polyacrylonitrile Blend Film. Polímeros: Ciência e Tecnologia, v. 23, n. 2, p. 146-151, 2013. 